\title{
Transition State Asymmetry in C-H Bond Cleavage by Proton-Coupled Electron Transfer
}

Julia W. Darcy ${ }^{\dagger}$, Scott S. Kolmar ${ }^{\dagger}$, and James M. Mayer*

†equal contribution

Department of Chemistry, Yale University, New Haven, CT 06520-8107, USA

\section{Table of Contents}

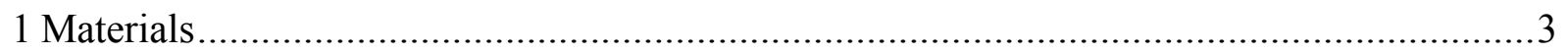

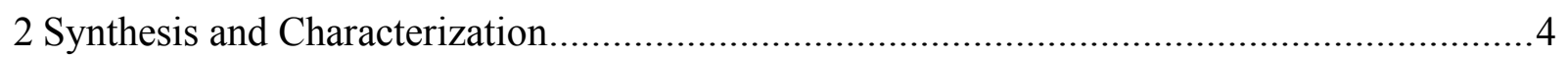

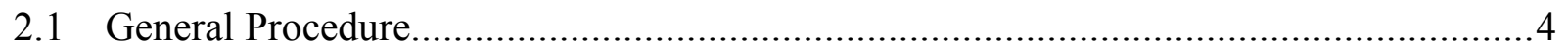

2.2 Experimental Determination of $\mathrm{p} K_{\mathrm{a}}$ 's

2.3 Stoichiometric ${ }^{1} \mathrm{H}$ NMR studies and characterization of lactone products..................... 10

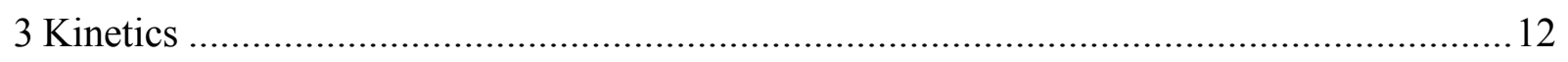

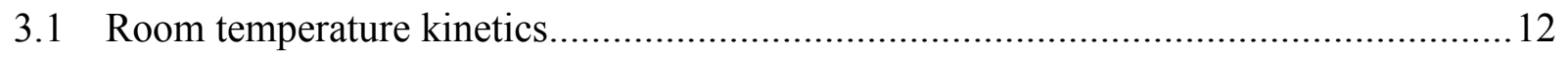

3.2 Tabulated values for $\Delta G^{\circ}{ }_{\text {rxn }}$ and $\log \left(K_{\text {eq }}\right)$ values with $\log \left(k_{\text {MS-CPET }}\right) \ldots \ldots \ldots \ldots \ldots \ldots \ldots \ldots \ldots \ldots . . . . . . . . . . . .13$

3.3 Tabulated Brønsted $\alpha$ values with varying oxidants................................................... 16

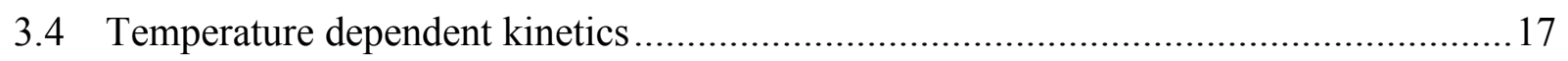

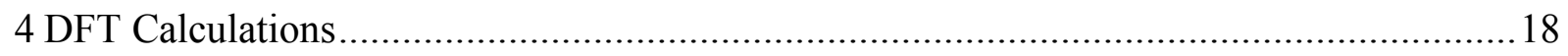

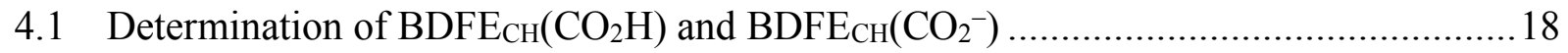

4.2 Internal Reaction Coordinate Calculation for Intramolecular Proton Transfer in

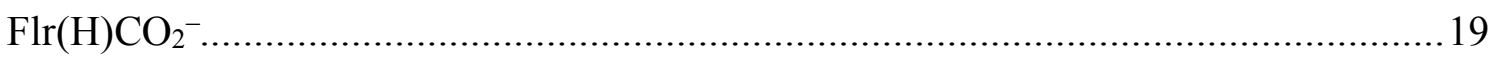

4.3 Internal Reaction Coordinate Calculation for MS-CPET Between $\operatorname{Fr}(\mathrm{H}) \mathrm{CO}_{2}{ }^{-}$and

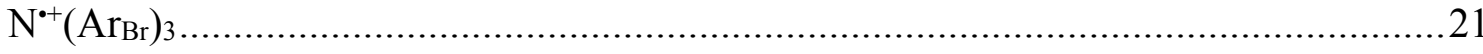

4.4 Comparison of Computational and Experimental $\Delta G_{\mathrm{rxn}}$ for the MS-CPET Reactions

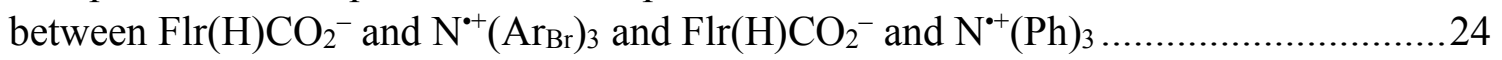

4.5 Internal Reaction Coordinate Calculation for MS-CPET between $\mathrm{Fr}(\mathrm{H}) \mathrm{CO}_{2}{ }^{-}$and

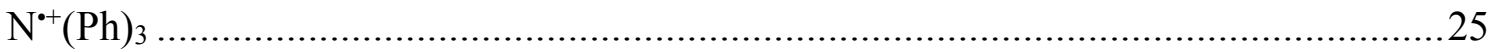

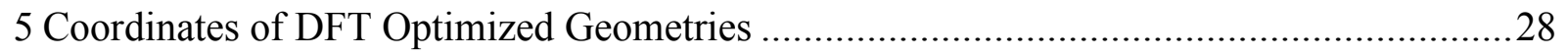

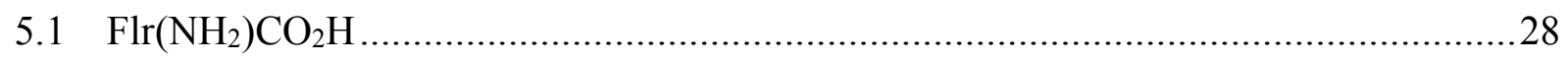

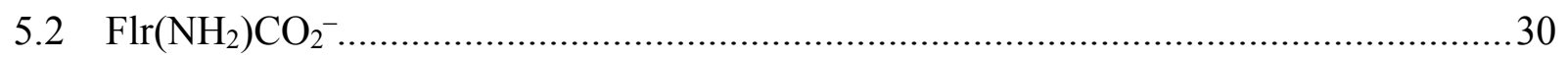

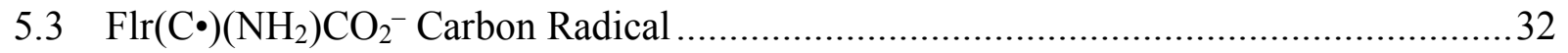

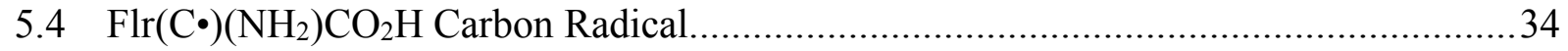

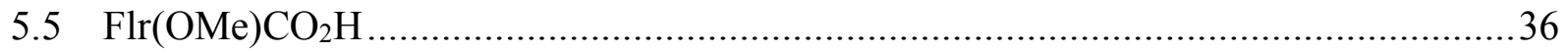

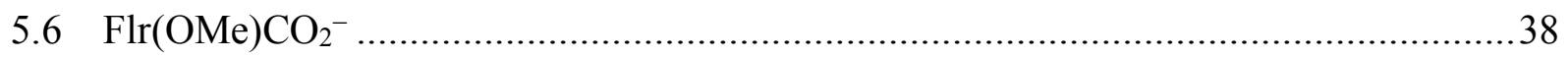


$5.7 \quad \mathrm{~F} \operatorname{lr}(\mathrm{C} \bullet)(\mathrm{OMe}) \mathrm{CO}_{2}{ }^{-}$Carbon Radical ................................................................... 40

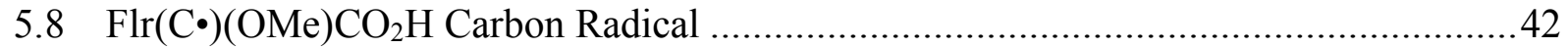

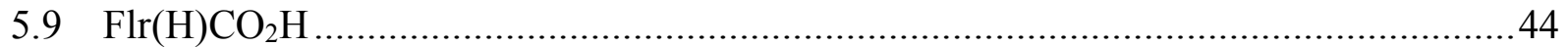

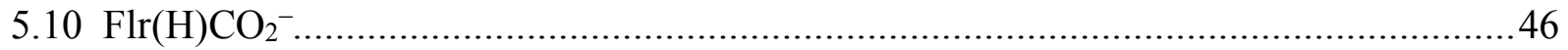

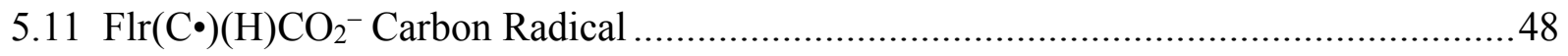

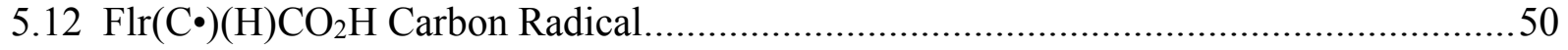

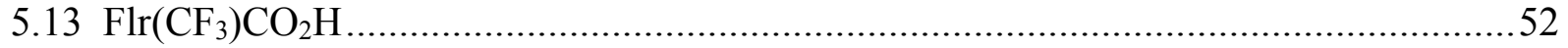

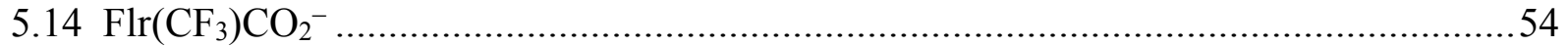

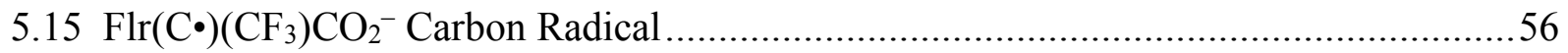

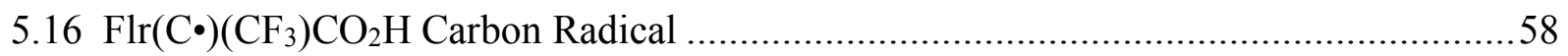

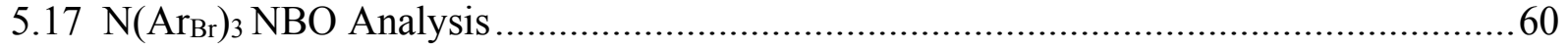

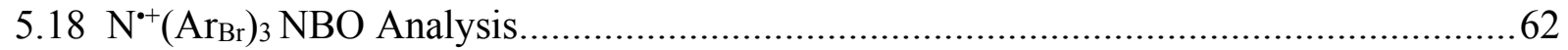

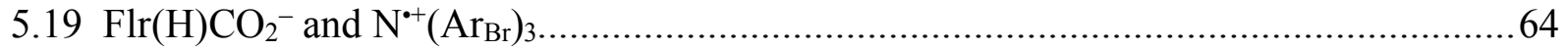

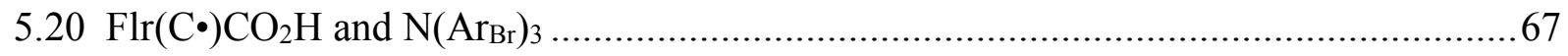

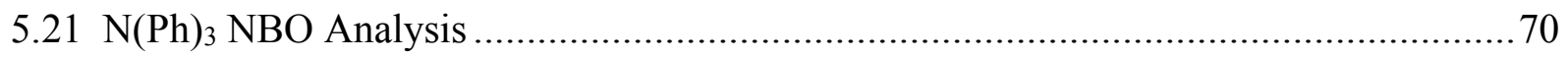

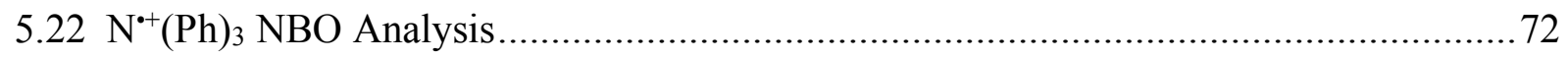

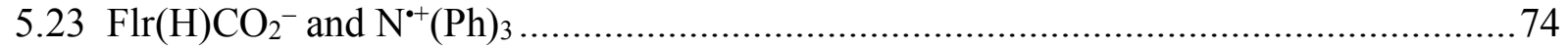

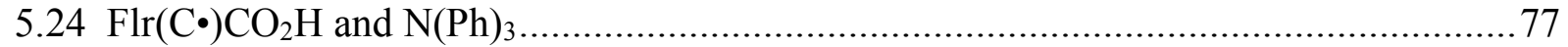

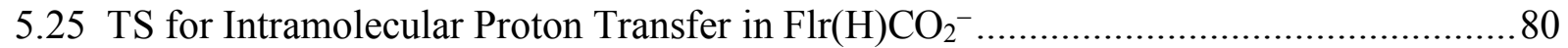

5.26 Internal Reaction Coordinate Calculation for Intramolecular Proton Transfer in

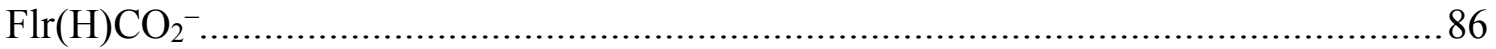

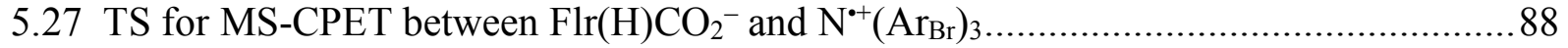

5.28 Internal Reaction Coordinate Calculation for MS-CPET between $\mathrm{F} \operatorname{lr}(\mathrm{H}) \mathrm{CO}_{2}{ }^{-}$and

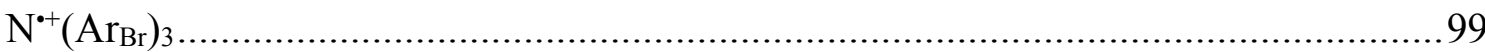

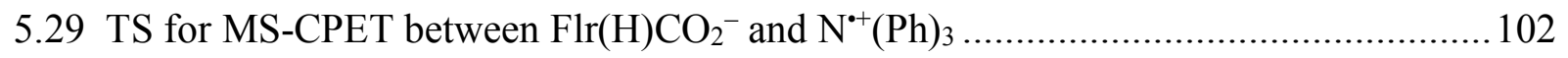

5.30 Internal Reaction Coordinate Calculation for MS-CPET between $\mathrm{F} \operatorname{lr}(\mathrm{H}) \mathrm{CO}_{2}{ }^{-}$and

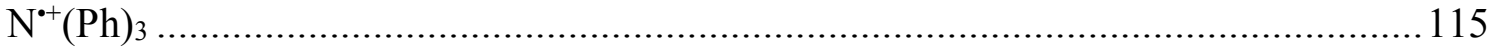

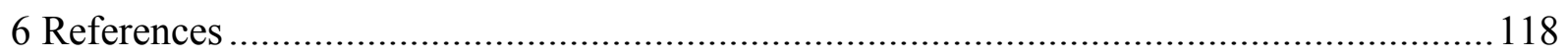




\section{Materials}

Reagents were typically purchased from Sigma Aldrich, Alfa Aesar, or Acros and used as received. Solvents were obtained from Fisher, deuterated solvents from Cambridge Isotope Laboratories. Unless otherwise noted, experiments were set up in an $\mathrm{N}_{2}$-filled glovebox using solvents that were sparged with argon and plumbed directly into the glovebox. Organic syntheses were performed outside of the glovebox. Dimethylformamide was purified using a Glass Contour Solvent Purification System (Pure Process Technology, LLC, Nashua, NH). Acetonitrile was Burdick Jackson low water grade and used without additional drying. All oxidants used were hexafluorophosphate $\left(\mathrm{PF}_{6}{ }^{-}\right)$salts. Aminium ${ }^{1}$ and ferrocenium ${ }^{2}$ oxidants were prepared as described previously. Oxidant $E_{1 / 2}$ values for the aminium oxidants and ferrocenium oxidants were taken from previous reports. ${ }^{1,2,3,4}$ NMR samples following MS-CPET reactions were prepared in an $\mathrm{N}_{2}$-filled glovebox using degassed, deuterated solvents dried over activated $3 \AA$ molecular sieves. NMR spectra were collected on Agilent DD2-400 MHz, $-500 \mathrm{MHz}$, or $-600 \mathrm{MHz}$ spectrometers. 


\section{Synthesis and Characterization}

\subsection{General Procedure}

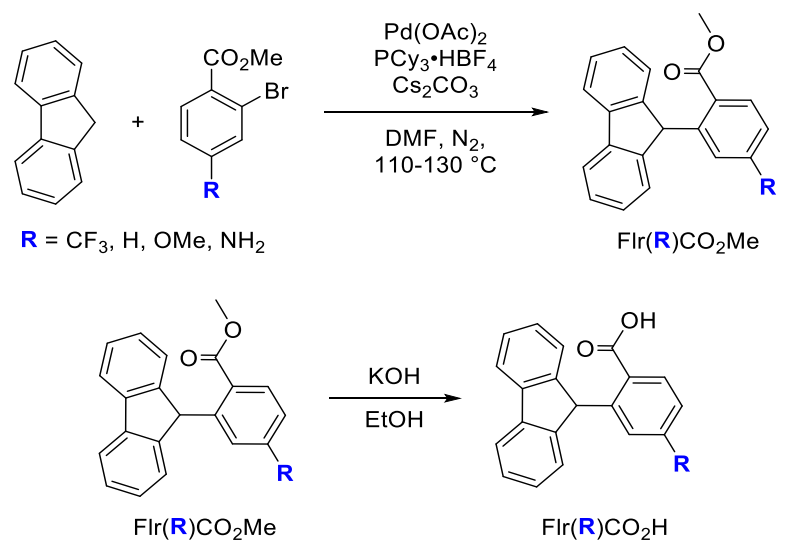

The methyl ester compounds $\mathrm{F} \operatorname{lr}(\mathrm{R}) \mathrm{CO}_{2} \mathrm{Me}$ were synthesized following procedures for related compounds (eq S1). ${ }^{5}$ Fluorene $(1.2 \mathrm{eq})$, the appropriate brominated methyl ester (1.0 eq), $\mathrm{Pd}(\mathrm{OAc})_{2}(2 \mathrm{~mol} \%), \mathrm{PCy}_{3} \cdot \mathrm{HBF}_{4}(4 \mathrm{~mol} \%)$, and $\mathrm{Cs}_{2} \mathrm{CO}_{3}(1.5 \mathrm{eq})$ were added to a thick-walled microwave reaction vial from Perkin Elmer that was equipped with a stir bar and sealed with a piercable crimp cap. The vial was evacuated and backfilled with $\mathrm{N}_{2}$ on a Schlenck line. DMF was taken directly from the solvent system and syringed into the reaction vial. Then, the reaction was heated at 110 or $130^{\circ} \mathrm{C}$ overnight $(\sim 16 \mathrm{hrs})$. The reaction was cooled to room temperature and diluted with $1 \mathrm{M} \mathrm{HCl}$. The aqueous layer was extracted with $\mathrm{Et}_{2} \mathrm{O}(3 \times 20 \mathrm{~mL})$, then the organic layer was washed with $1 \mathrm{M} \mathrm{HCl}(2 \times 20 \mathrm{~mL}), \mathrm{H}_{2} \mathrm{O}(2 \times 20 \mathrm{~mL})$ and brine $(20 \mathrm{~mL})$. The organic layer was dried over $\mathrm{MgSO}_{4}$ and solvent evaporated. The crude reaction mixture was purified on a silica gel column in 5\% EtOAc:hexanes eluent.

$\mathrm{F} \operatorname{lr}(\mathrm{R}) \mathrm{CO}_{2} \mathrm{Me}$ were then treated with basic hydroloysis to yield the corresponding carboxylic acid $\left(\mathrm{F} 1 \mathrm{r}(\mathrm{R}) \mathrm{CO}_{2} \mathrm{H}\right.$, eq $\left.\mathrm{S} 2\right)$. In a typical procedure, the isolated methyl ester ( $\left.\sim \mathrm{mmol}\right)$ was added to a degassed solution of ethanol $(120 \mathrm{~mL})$ and $3 \mathrm{M}$ aqueous $\mathrm{KOH}(30 \mathrm{~mL})$. The solution was refluxed until the methyl ester starting material was completely consumed (usually in about 15-30 minutes). The reaction mixture was cooled to room temperature and diluted with $1 \mathrm{M} \mathrm{HCl}_{a q}(100 \mathrm{~mL})$ and washed with $\mathrm{Et}_{2} \mathrm{O}(3 \times 20 \mathrm{~mL})$. Characterization data for the parent $\mathrm{F} \operatorname{lr}(\mathrm{H}) \mathrm{CO}_{2} \mathrm{H}$ compound was previously reported. ${ }^{4}$

\section{$\operatorname{Flr}\left(\mathrm{NH}_{2}\right) \mathrm{CO}_{2} \mathrm{H}$}

The title compound was synthesized according to the general procedure above at $110{ }^{\circ} \mathrm{C}$.

${ }^{1} \mathrm{H}$ NMR $\left(400 \mathrm{MHz}, \mathrm{CDCl}_{3}\right) \delta 8.04(\mathrm{~d}, 1 \mathrm{H}), 7.80(\mathrm{~d}, 2 \mathrm{H}), 7.35(\mathrm{~m}, 4 \mathrm{H}), 7.25(\mathrm{~m}, 2 \mathrm{H}$, overlapping with $\left.\mathrm{CDCl}_{3}\right), 6.60(\mathrm{~s}, 1 \mathrm{H}), 6.49(\mathrm{dd}, 1 \mathrm{H}), 5.74(\mathrm{~d}, 1 \mathrm{H}), 3.78$ (broad s, 1-2 H).

${ }^{13} \mathrm{C}$ NMR $\left(600 \mathrm{MHz} \mathrm{CDCl}_{3}\right) \delta 170.8,150.8,148.4,147.3,141.1,134.1,127.3,127.0,125.6$, $119.7,117.5,114.0,112.6,110.0,49.9$.

\section{$\mathrm{F} \operatorname{lr}(\mathrm{OMe}) \mathrm{CO}_{2} \mathrm{H}$}

The title compound was synthesized according to the general procedure above at $130{ }^{\circ} \mathrm{C}$. 
${ }^{1} \mathrm{H}$ NMR $\left(400 \mathrm{MHz}, \mathrm{CDCl}_{3}\right) \delta 11.14$ (b.s., $\left.1 \mathrm{H}, \mathrm{COOH}\right), 8.17(\mathrm{~d}, 1 \mathrm{H}), 7.78(\mathrm{~d}, 2 \mathrm{H}), 7.33(\mathrm{~m}, 4 \mathrm{H})$, $7.24\left(\mathrm{~m}, 2 \mathrm{H}\right.$, overlapping with $\left.\mathrm{CDCl}_{3}\right), 6.77(\mathrm{~d}$ of $\mathrm{d}, 1 \mathrm{H}), 6.56(\mathrm{~s}, 1 \mathrm{H}, \mathrm{Flr}-9 \mathrm{H}), 6.03(\mathrm{~m}, 1 \mathrm{H}), 3.55$ (s, 3H, OMe).

${ }^{13} \mathrm{C}$ NMR $\left(600 \mathrm{MHz}, \mathrm{CDCl}_{3}\right) \delta 172.74,163.39,148.26,147.67,141.34,134.23,127.48,127.32$, $125.63,121.09,120.03,114.72,112.10,55.30,50.22$.

\section{$\mathrm{F} \operatorname{lr}\left(\mathrm{CF}_{3}\right) \mathrm{CO}_{2} \mathrm{H}$}

The title compound was synthesized according to the general procedure above at $110{ }^{\circ} \mathrm{C}$.

${ }^{1} \mathrm{H}$ NMR (400 MHz, $\left.\mathrm{CDCl}_{3}\right) \delta 11.30$ (b.s., 1H, COOH), 8.19 (d, 1H), $7.82(\mathrm{~d}, 2 \mathrm{H}), 7.53(\mathrm{~d}, 1 \mathrm{H})$, $7.48(\mathrm{t}, 2 \mathrm{H}), 7.25(\mathrm{~m}, 4 \mathrm{H}), 6.75(\mathrm{~s}, 1 \mathrm{H}), 6.31(\mathrm{~s}, 1 \mathrm{H}, \mathrm{Flr}-9 \mathrm{H})$

${ }^{13} \mathrm{C}$ NMR $\left(600 \mathrm{MHz}, \mathrm{CDCl}_{3}\right) \delta 171.69,147.38,145.58,141.38,132.42,131.76,127.83,127.74$, $126.43,125.50,123.74,120.33,49.95$.

${ }^{19}$ F NMR (400 MHz, CDCl3) $\delta(p p m)-63.35$

\subsection{Experimental Determination of $\mathrm{p} K_{\mathrm{a}}$ 's}

Measurements of the $\mathrm{p} K_{\mathrm{a}}$ 's were performed in an $\mathrm{N}_{2}$-filled glovebox in $\mathrm{CD}_{3} \mathrm{CN}$. Measurements were made by equilibrating the $\mathrm{F} \operatorname{r}(\mathrm{R}) \mathrm{CO}_{2}^{-}$substrates with a known amount of 4-trifluoromethyl benzoic acid (TFBA). TFBA was chosen because the trifluoromethyl group provides a convenient ${ }^{19} \mathrm{~F}$ NMR handle. To determine the chemical shift of the species in protonated form $\left(\delta_{\mathrm{COOH}}\right),{ }^{1} \mathrm{H} /{ }^{19} \mathrm{~F}$ NMR spectra were measured in $\mathrm{CD}_{3} \mathrm{CN}$. The substrates were then deprotonated with a superstoichiometric amount of 1,8-diazabicyclo[5.4.0] undec-7-ene (DBU) in $\mathrm{CH}_{3} \mathrm{CN}$ and ${ }^{1} \mathrm{H} /{ }^{19} \mathrm{~F}$ NMR spectra were measured to determine the chemical shift of the species in deprotonated form $\left(\delta_{\text {COO- }}\right)$.

A solution of $\mathrm{F} \operatorname{lr}(\mathrm{R}) \mathrm{CO}_{2} \mathrm{H}$ and a substiochiometric amount of DBU were equilibrated, aliquots of added, and the solution equilibrated. Then, ${ }^{1} \mathrm{H} /{ }^{19} \mathrm{~F}$ NMR were measured in a sealed J-Young tube to determine the chemical shifts of the equilibrated species $\left(\delta_{\text {eq }}\right)$. The fluorenyl $\mathrm{C}-\mathrm{H}$ peak was typically chosen as the ${ }^{1} \mathrm{H}$ NMR handle for the substrate. For the $\mathrm{F} \operatorname{lr}\left(\mathrm{CF}_{3}\right) \mathrm{CO}_{2} \mathrm{H}$ substrate an aryl $\mathrm{C}-\mathrm{H}$ peak was chosen as the ${ }^{1} \mathrm{H}$ NMR handle. The chemical shifts of the equilibrated reaction mixtures were observed to fall between $\delta_{\mathrm{COOH}}$ and $\delta_{\mathrm{COO}-}$. The chemical shifts were used to calculate percent protonation ( $\%$ p) of each species according to the following equation.

$$
\% p=\frac{\delta_{e q}-\delta_{\mathrm{COO}-}}{\delta_{\mathrm{COOH}}-\delta_{\mathrm{COO}-}}
$$

To determine the relative $\mathrm{p} K_{\mathrm{a}}$ of the two acids $\left(\Delta \mathrm{p} K_{\mathrm{a}}\right)$, the following expressions were used. The equilibrium between the two acids can be expressed as a quotient of the two dissociation constants $K_{1}$ and $K_{2}$. The spectra for the relative $\mathrm{p} K_{\mathrm{a}}$ measurements between $\mathrm{Flr}\left(\mathrm{NH}_{2}\right) \mathrm{CO}_{2} \mathrm{H}$ and TFBA are shown below in 


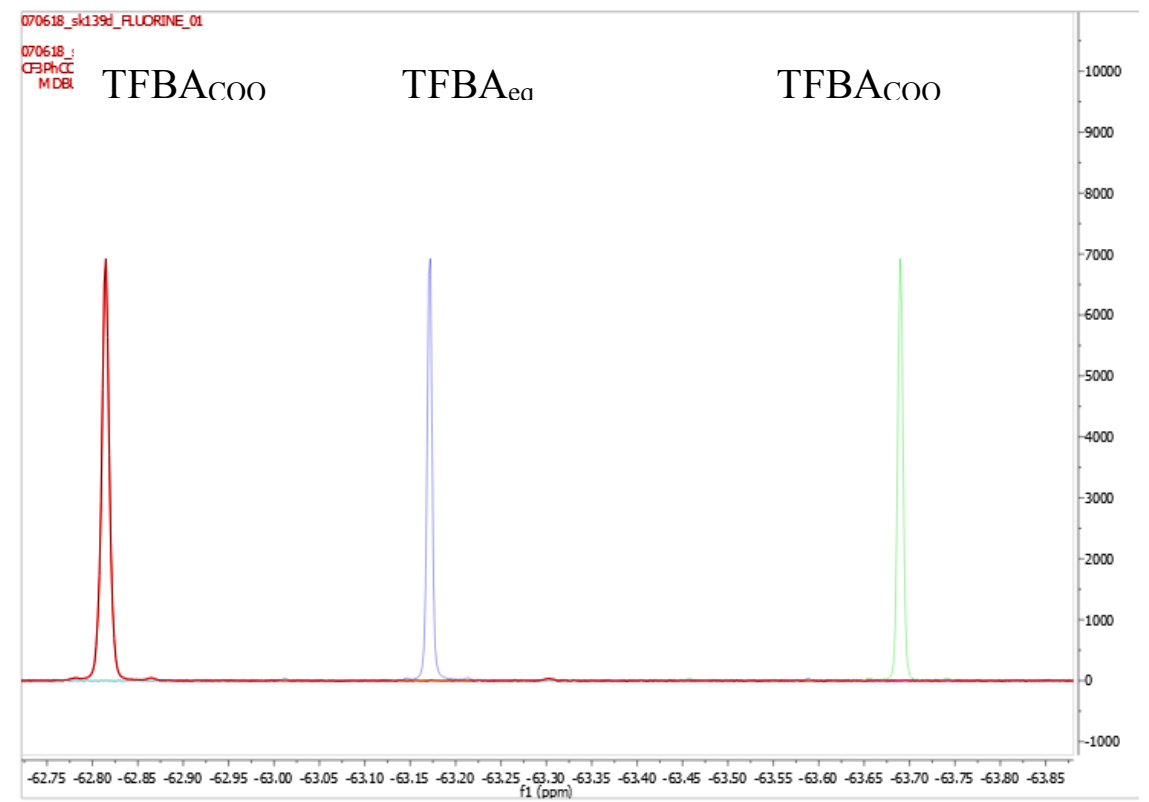

Figure S2.1 and Figure S2.2. The data for all the relative $\mathrm{p} K_{\mathrm{a}}$ measurements are shown in

Table S2.1 below. Measurements were also performed on benzoic acid (BA) to anchor the $\mathrm{p} K_{\mathrm{a}}$ scale against a known absolute value $\left(\mathrm{p} K_{\mathrm{a}}=21.5 \mathrm{MeCN}\right){ }^{6}$

$$
\begin{gathered}
\mathrm{COOH}_{1}+\mathrm{COO}_{2}^{-} \rightleftharpoons \mathrm{COO}_{1}^{-}+\mathrm{COOH}_{2} \\
\mathrm{COOH} \rightleftharpoons \mathrm{COO}^{-}+\mathrm{H}^{+} \\
K_{1}=\frac{\left[\mathrm{COO}_{1}^{-}\right]\left[\mathrm{H}^{+}\right]}{\left[\mathrm{COOH}_{1}\right]} \\
K_{2}=\frac{\left[\mathrm{COO}_{2}^{-}\right]\left[\mathrm{H}^{+}\right]}{\left[\mathrm{COOH}_{2}\right]} \\
\frac{K_{1}}{K_{2}}=\frac{\left[\mathrm{COO}_{1}^{-}\right]\left[\mathrm{COOH}_{2}\right]}{\left[\mathrm{COOH}_{1}\right]\left[\mathrm{COO}_{2}^{-}\right]} \\
\log \left(\frac{K_{1}}{K_{2}}\right)=\log \left(\frac{\left[\mathrm{COO}_{1}^{-}\right]\left[\mathrm{COOH}_{2}\right]}{\left[\mathrm{COOH}_{1}\right]\left[\mathrm{COO}_{2}^{-}\right]}\right) \\
\log \left(\mathrm{K}_{1}-\mathrm{K}_{2}\right)=\log \left(\frac{\left[\mathrm{COO}_{1}^{-}\right]\left[\mathrm{COOH}_{2}\right]}{\left[\mathrm{COOH}_{1}\right]\left[\mathrm{COO}_{2}^{-}\right]}\right) \\
p K_{2}-p K_{1}=\log \left(\frac{\left[\mathrm{COO}_{1}^{-}\right]\left[\mathrm{COOH}_{2}\right]}{\left[\mathrm{COOH}_{1}\right]\left[\mathrm{COO}_{2}^{-}\right]}\right) \\
\Delta p K_{a}=\log \left(\frac{\left[\mathrm{COO}_{1}^{-}\right]\left[\mathrm{COOH}_{2}\right]}{\left[\mathrm{COOH}_{1}\right]\left[\mathrm{COO}_{2}^{-}\right]}\right)
\end{gathered}
$$




$$
\Delta p K_{a}=\log \left(\frac{\left(1-\% p_{1}\right) \% p_{2}}{\% p_{1}\left(1-\% p_{2}\right)}\right)
$$




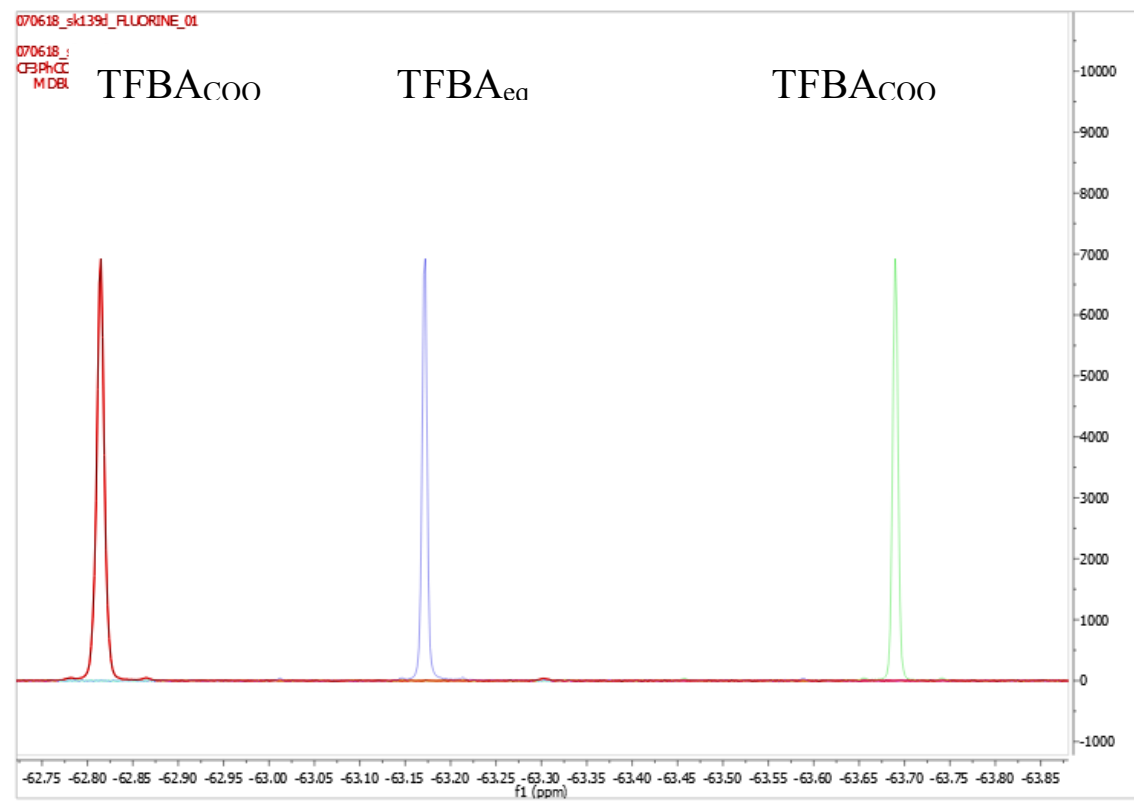

Figure S2.1. Overlaid ${ }^{19} \mathrm{~F}$ NMR spectra of protonated TFBA (green), deprotonated TFBA (maroon), and $4.6 \mathrm{mM}$ TFBA equilibrated with preequilibrated $3.7 \mathrm{mM} \mathrm{Flr}\left(\mathrm{NH}_{2}\right) \mathrm{CO}_{2} \mathrm{H}$ (blue) and $1.9 \mathrm{mM}$ DBU.

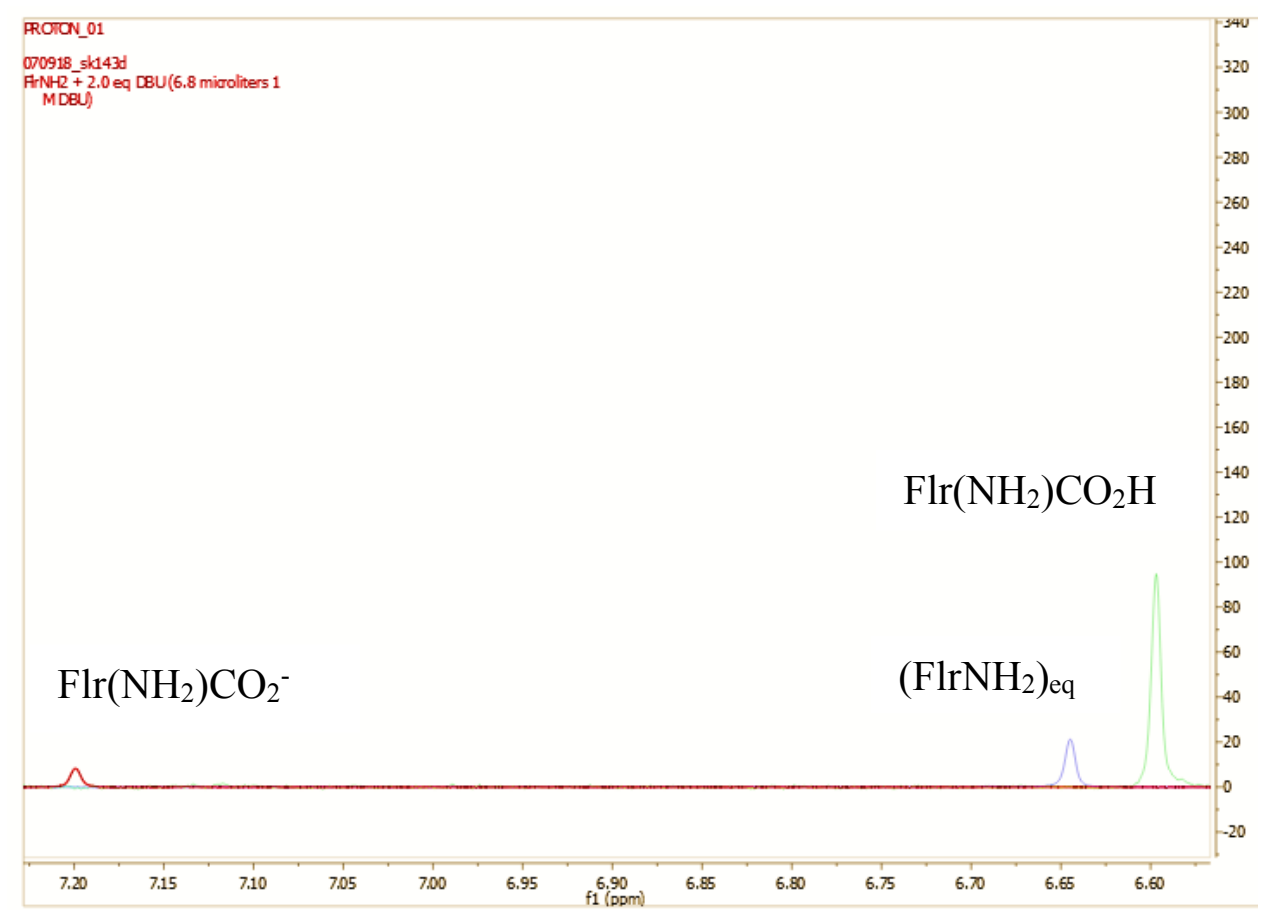

Figure S2.2. Overlaid ${ }^{1} \mathrm{H}$ NMR spectra in the 26.5 - 7.3 ppm region of $\mathrm{Flr}\left(\mathrm{NH}_{2}\right) \mathrm{CO}_{2} \mathrm{H}$ (green), Flr $\left(\mathrm{NH}_{2}\right) \mathrm{CO}_{2}^{-}$(maroon), and $4.6 \mathrm{mM}$ TFBA equilibrated with preequilibrated $3.7 \mathrm{mM}$ Flr $\left(\mathrm{NH}_{2}\right) \mathrm{CO}_{2} \mathrm{H}$ (blue) and $1.9 \mathrm{mM}$ DBU. 
Table S2.1. Chemical shifts of selected peaks of protonated and deprotonated $\mathrm{Flr}(\mathrm{R}) \mathrm{CO}_{2} \mathrm{H}$ and TFBA, mole fraction of protonated $\mathrm{F} \operatorname{lr}(\mathrm{R}) \mathrm{CO}_{2} \mathrm{H}$ and TFBA for equilibrated solutions of $\mathrm{F} \operatorname{lr}(\mathrm{R}) \mathrm{CO}_{2} \mathrm{H}$ and TFBA, and relative $\mathrm{p} K_{\mathrm{a}}$ data $\left(\mathrm{p} K_{\mathrm{a}}\left[\mathrm{Flr}(\mathrm{R}) \mathrm{CO}_{2} \mathrm{H}\right]-\mathrm{p} K_{\mathrm{a}}[\mathrm{TFBA}]\right)$.

\begin{tabular}{|c|c|c|c|c|c|c|c|}
\hline Substrate & $\begin{array}{l}\delta_{\mathrm{COOH}} \\
(\mathbf{p p m})\end{array}$ & $\begin{array}{l}\delta_{\mathrm{COO}-} \\
(\mathbf{p p m})\end{array}$ & $\begin{array}{l}\delta_{\text {eqsub }} \\
(\mathbf{p p m})\end{array}$ & $\% p$ & $\begin{array}{l}\boldsymbol{\delta}_{\text {eqTFBA }} \\
(\text { ppm) }\end{array}$ & $\% \mathbf{p}_{\text {TFва }}$ & $\Delta \mathrm{p} K_{\mathrm{a}}$ \\
\hline $\mathrm{Flr}\left(\mathrm{NH}_{2}\right) \mathrm{CO}_{2} \mathrm{H}$ & 6.59 & 7.20 & 6.64 & 0.92 & -63.17 & 0.41 & +1.24 \\
\hline $\mathrm{F} \operatorname{lr}(\mathrm{OMe}) \mathrm{CO}_{2} \mathrm{H}$ & 6.53 & 7.08 & 6.66 & 0.76 & -63.13 & 0.36 & +0.75 \\
\hline \multirow[t]{3}{*}{$\mathrm{Flr}(\mathrm{H}) \mathrm{CO}_{2} \mathrm{H}^{a}$} & 6.33 & 6.69 & 6.36 & 0.92 & -63.51 & 0.80 & +0.46 \\
\hline & - & - & 6.38 & 0.85 & -63.37 & 0.64 & +0.50 \\
\hline & - & - & 6.41 & 0.76 & -63.22 & 0.47 & +0.55 \\
\hline $\begin{array}{l}\mathrm{Flr}\left(\mathrm{CF}_{3}\right) \mathrm{CO}_{2} \mathrm{H} \\
\left({ }^{1} \mathbf{H}\right)\end{array}$ & 7.63 & 7.90 & 7.76 & 0.56 & 7.76 & 0.76 & -0.40 \\
\hline $\begin{array}{l}\mathrm{FIr}\left(\mathrm{CF}_{3}\right) \mathrm{CO}_{2} \mathrm{H} \\
\left({ }^{19} \mathrm{~F}\right)\end{array}$ & -63.95 & -62.95 & -63.48 & 0.53 & -63.48 & 0.76 & -0.45 \\
\hline \multirow[t]{3}{*}{$\begin{array}{l}\mathbf{B A}^{\mathrm{a}} \\
\left(\text { using TFBA }^{1} \mathbf{H}\right)\end{array}$} & 7.65 & 7.260 & 7.64 & 0.97 & 7.795 & 0.86 & +0.72 \\
\hline & - & - & 7.62 & 0.92 & 7.75 & 0.67 & +0.75 \\
\hline & - & - & 7.59 & 0.85 & 7.73 & 0.58 & +0.61 \\
\hline \multirow[t]{3}{*}{$\begin{array}{l}\mathrm{BA}^{\mathrm{a}} \\
\left(\mathrm{using} \text { TFBA }{ }^{19} \mathrm{~F}\right)\end{array}$} & 7.65 & 7.26 & 7.64 & 0.97 & -63.55 & 0.84 & +0.79 \\
\hline & - & - & 7.62 & 0.92 & -63.35 & 0.61 & +0.86 \\
\hline & - & - & 7.59 & 0.85 & -63.22 & 0.47 & +0.84 \\
\hline TFBA $\left({ }^{1} \mathbf{H}\right)$ & 7.81 & 7.62 & - & - & - & - & - \\
\hline TFBA $\left({ }^{19} F\right)$ & -63.69 & -62.81 & - & - & - & - & - \\
\hline
\end{tabular}

${ }^{a}$ Repeated three times with a different initial amount of DBU: $0.25,0.50$, or 0.75 equivalents with respect to $\operatorname{Fr}(\mathrm{H}) \mathrm{CO}_{2} \mathrm{H}$ or BA. 


\subsection{Stoichiometric ${ }^{1} \mathrm{H}$ NMR studies and characterization of lactone products}

Reactions were performed in an $\mathrm{N}_{2}$-filled glovebox in $\mathrm{CD}_{3} \mathrm{CN}$. $\mathrm{F} \operatorname{lr}(\mathrm{R}) \mathrm{CO}_{2}^{-}$was deprotonated in situ with 0.9 eq TBAOH (as a $1 \mathrm{M}$ solution in $\mathrm{MeOH}$ ). Then, 1.0 eq of oxidant (aminium or ferrocenium) was added to the carboxylate. A ${ }^{1} \mathrm{H}$ NMR of the reaction mixture was taken. For each derivative, the reaction mixture showed the protonated carboxylic acid starting material and a new product in about 1:1 ratio, as previously reported for the parent substrate. ${ }^{4}$ Addition of a second equivalent of both base and oxidant resulted in full conversion to the lactone, which was characterized by ${ }^{1} \mathrm{H} \mathrm{NMR},{ }^{13} \mathrm{C} \mathrm{NMR}$, and mass spectrometry (see below).

A representative series of spectra for the reaction of $\mathrm{Flr}(\mathrm{OMe}) \mathrm{CO}_{2}{ }^{-}$and $\mathrm{FcPF}_{6}$ is shown in Figure S2.3. As shown, addition of 0.9 eq base and 1 eq oxidant results in the formation of the protonated starting material (by comparison to a known sample) and the $2 e^{-}$oxidized lactone. Addition of a second equivalent of base and oxidant resulted in complete conversion to the lactone. For $\mathrm{F} \operatorname{lr}(\mathrm{OMe}) \mathrm{CO}_{2}^{-}$, the lactone product is observed using either $\mathrm{FcPF}_{6}$ or $\mathrm{N}\left(\mathrm{Ar}_{\mathrm{OMe}}\right)_{3}{ }^{*+}$.

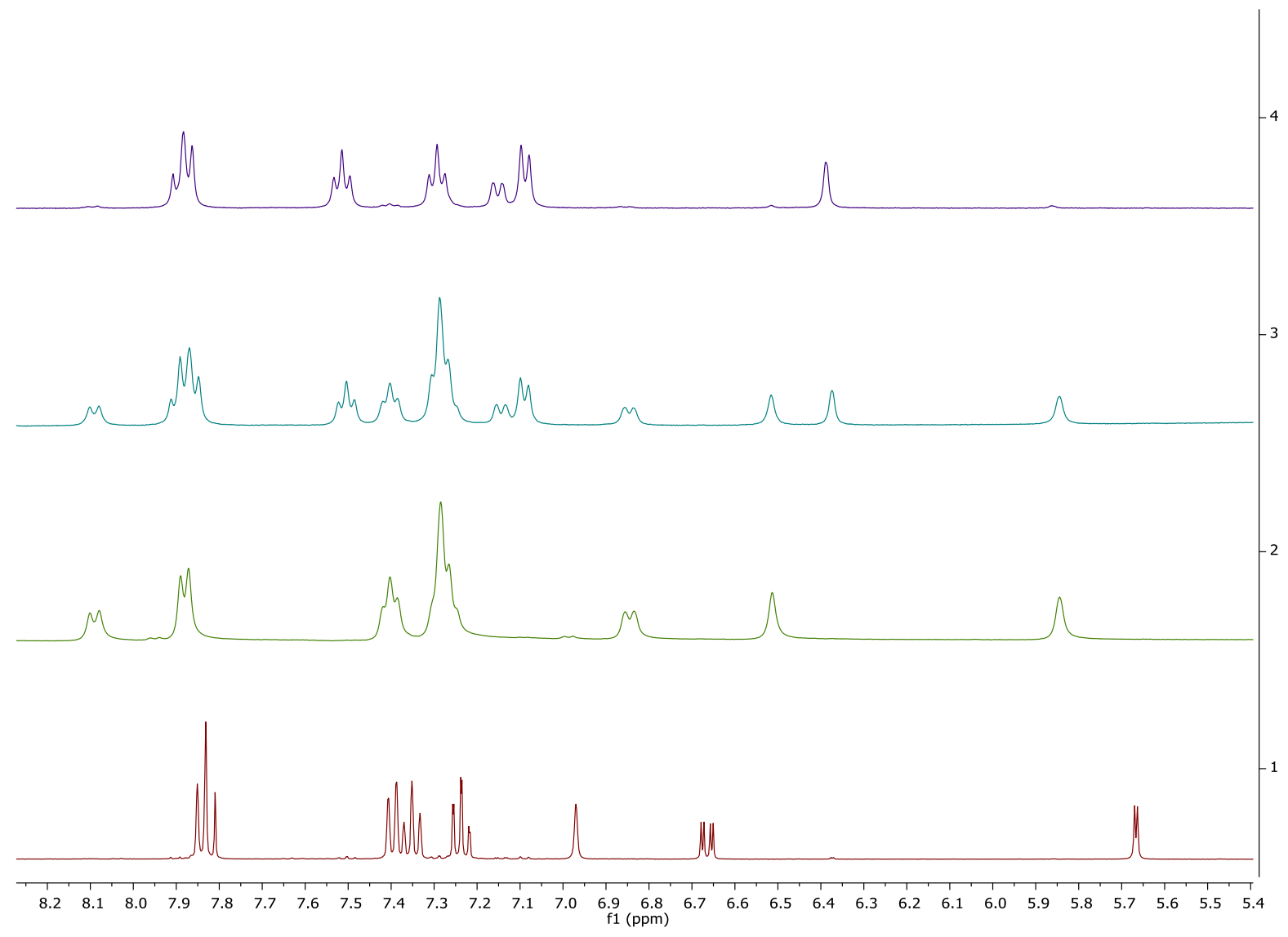

Figure S2.3. Representative ${ }^{1} \mathrm{H}$ NMR spectra for the reaction of $\mathrm{F} \operatorname{lr}(\mathrm{OMe}) \mathrm{CO}_{2} \mathrm{H}$ with $\mathrm{TBAOH}$ and $\mathrm{FcPF}_{6}$. Only the aromatic region is shown. (spectrum 1, red) $\mathrm{F} \operatorname{lr}(\mathrm{OMe}) \mathrm{CO}_{2} \mathrm{H}+\mathrm{TBAOH}(0.9$ eq). (spectrum 2, green) $\mathrm{Flr}(\mathrm{OMe}) \mathrm{CO}_{2} \mathrm{H}$. (spectrum 3, blue) Flr(OMe) $\mathrm{CO}_{2} \mathrm{H}+\mathrm{TBAOH}(0.9$ eq $)+$ $\mathrm{FcPF}_{6}\left(1.0\right.$ eq). (spectrum 4, purple) $\mathrm{F} \operatorname{lr}(\mathrm{OMe}) \mathrm{CO}_{2} \mathrm{H}+\mathrm{TBAOH}(1.8$ eq $)+\mathrm{FcPF}_{6}$ (2.0 eq) 


\section{FIr( $\left.\mathbf{N H}_{2}\right)$-lactone}

${ }^{1} \mathrm{H}$ NMR (400 MHz, CD $\left.{ }_{3} \mathrm{CN}\right) \delta(\mathrm{ppm}) 7.87(\mathrm{~d}, 2 \mathrm{H}), 7.67(\mathrm{~d}, 1 \mathrm{H}), 7.52(\mathrm{t}, 2 \mathrm{H}), 7.31(\mathrm{t}, 2 \mathrm{H}), 7.12$ $(\mathrm{d}, 2 \mathrm{H}), 6.80(\mathrm{~d}$ of $\mathrm{d}, 1 \mathrm{H}), 5.92(\mathrm{~d}, 1 \mathrm{H})$

${ }^{13} \mathrm{C}$ NMR $\left(600 \mathrm{MHz}, \mathrm{CD}_{3} \mathrm{CN}\right) \delta(\mathrm{ppm}) 154.26,144.75,141.39,131.30,129.59,128.26,127.69$, 126.22, 125.09, 121.62, 116.78, 105.01, 59.27.

\section{FIr(OMe)-lactone}

${ }^{1} \mathrm{H}$ NMR (400 MHz, CD $\left.{ }_{3} \mathrm{CN}\right) \delta(\mathrm{ppm}) 7.88(\mathrm{t}, 3 \mathrm{H}), 7.51(\mathrm{t}, 2 \mathrm{H}), 7.29(\mathrm{t}, 2 \mathrm{H}), 7.15(\mathrm{~d}, 1 \mathrm{H}), 7.09$ $(\mathrm{d}, 2 \mathrm{H}), 6.38(\mathrm{~s}, 1 \mathrm{H}), 3.67(\mathrm{~s}, 3 \mathrm{H})$

${ }^{13} \mathrm{C}$ NMR $\left(600 \mathrm{MHz}, \mathrm{CD}_{3} \mathrm{CN}\right) \delta(\mathrm{ppm}) 170.60,166.40,154.02,143.97,131.46,129.53,127.70$, $125.13,121.67,106.30,91.80,59.18$.

\section{$\operatorname{Flr}\left(\mathrm{CF}_{3}\right)$-lactone}

${ }^{1} \mathrm{H}$ NMR (400 MHz, CD $\left.3 \mathrm{CN}\right) \delta(\mathrm{ppm}) 8.20(\mathrm{~d}, 1 \mathrm{H}), 7.98(\mathrm{~d}, 1 \mathrm{H}), 7.91(\mathrm{~d}, 2 \mathrm{H}), 7.56(\mathrm{t}, 2 \mathrm{H}), 7.32$ $(\mathrm{m}, 3 \mathrm{H}), 7.14(\mathrm{~d}, 2 \mathrm{H})$

${ }^{13} \mathrm{C}$ NMR (600 MHz, CD 3 CN) $\delta$ (ppm) 151.78, 142.93, 142.09, 141.84, 131.93, 129.75, 127.64, $125.43,121.94,121.20,120.54,59.29,59.27,59.25$.

${ }^{19} \mathrm{~F}$ NMR $\left(400 \mathrm{MHz}, \mathrm{CD}_{3} \mathrm{CN}\right) \delta(\mathrm{ppm})-63.94$ 


\section{Kinetics}

\subsection{Room temperature kinetics}

Stopped flow measurements made at room temperature were taken on an Olis RSM-1000 single mixing stopped flow instrument. Solutions were made in anaerobic MeCN (Burdick Jackson low water) that was sparged with argon and plumbed directly into an $\mathrm{N}_{2}$-filled glovebox. All solutions used for kinetics were prepared in a $\mathrm{N}_{2}$-filled glovebox and used within an hour of preparation. All measurements were made at $295 \pm 2 \mathrm{~K}$. The wavelength window $(\sim 200 \mathrm{~nm})$ was set to include the $\lambda_{\max }$ of the oxidant. The lines were flushed with anaerobic $\mathrm{MeCN}$, followed by solutions of the carboxylate and oxidant before data collection was initiated.

For aminium oxidants, a stock solution of $\mathrm{F} \operatorname{lr}(\mathrm{R}) \mathrm{CO}_{2} \mathrm{H}(5-10 \mathrm{mM})$ was deprotonated with 0.9 equivalents of $\mathrm{TBAOH}$ in $\mathrm{MeOH}$. Serial dilutions of the stock material were made in $5 \mathrm{~mL}$ volumetric flasks to give solutions ranging from 6-30 eq of carboxylate relative to the oxidant. The appropriate amount of $\mathrm{MeOH}$ was added to the volumetric flask to make $[\mathrm{MeOH}]$ constant for all of the solutions of $\mathrm{F} \operatorname{lr}(\mathrm{R}) \mathrm{CO}_{2}{ }^{-}$. Stock solutions of the aminium oxidants were $\sim 30 \mu \mathrm{M}$ in $\mathrm{MeCN}$. All solutions were loaded into gas tight syringes. Note that these concentrations were halved by stopped flow mixing. Experiments with aminium oxidants had $[\mathrm{MeOH}]=0.2 \%$ by volume after mixing in the stopped flow.

For ferrocenium oxidants, a stock solution of $\mathrm{F} \operatorname{lr}(\mathrm{R}) \mathrm{CO}_{2} \mathrm{H}(5-10 \mathrm{mM})$ was deprotonated with 0.9 equivalents $\mathrm{TBAOH}$ in $\mathrm{MeOH}$. Serial dilutions of the stock material were made in $5 \mathrm{~mL}$ volumetric flasks to give solutions ranging from 4-6 eq of $\mathrm{F} \operatorname{lr}(\mathrm{R}) \mathrm{CO}_{2}{ }^{-}$relative to the oxidant. The appropriate amount of $\mathrm{MeOH}$ was added to the volumetric flask to make $[\mathrm{MeOH}]$ constant for all of the solutions of $\mathrm{Flr}(\mathrm{R}) \mathrm{CO}_{2}{ }^{-}$. Stock solutions of the ferrocenium oxidants were $\sim 1 \mathrm{mM}$ in $\mathrm{MeCN}$. Solutions were loaded into gas tight syringes. Note that these concentrations were halved after mixing on the stopped flow. Experiments with ferrocenium oxidants had $[\mathrm{MeOH}]=0.4 \%$ by volume after mixing.

The absorbance $v s$. time data monitor the disappearance of the colored oxidants. These data were analyzed with Specfit global analysis software. ${ }^{7}$ Reactions performed with aminium oxidants were under pseudo first order conditions and fit to a first order model. For each concentration of carboxylate, $k_{\text {obs }}$ was calculated as the average of 5 separate runs, with standard deviations within the $10 \%$ experimental uncertainty. A plot of $k_{\text {obs }}$ vs. [ $\left.\mathrm{Flr}(\mathrm{R}) \mathrm{CO}_{2}{ }^{-}\right]$was then used to obtain the second-order rate constant for the reaction. A representative data set using an aminium oxidant is shown below (Figure S3.1 A and B).

Reactions performed with ferrocenium oxidants were fit to a second-order model in SpecFit. For each concentration of carboxylate, the second order rate constants were calculated as the average of 5 separate runs. The second order rate constants at each concentration were then averaged to give the reported second-order rate constants. A representative data set using a ferrocenium oxidant is shown below (Figure S3.1 C and D). Experimental results are tabulated in Tables 1 and 2 of the main manuscript.

Reactions of the carboxylates with the oxidants generally fit very well to second-order models, with a few exceptions. Reactions of both the $\mathrm{NH}_{2}$ - and $\mathrm{CF}_{3}$-derivatives with the stronger aminium oxidants (e.g. $\left.\mathrm{N}^{*+}\left(\mathrm{Ar}_{\mathrm{OMe}}\right)\left(\mathrm{Ar}_{\mathrm{Br}}\right)_{2}\right)$ display deviations from the second-order model. In the case of the $\mathrm{NH}_{2}$-derivative, deviations from second-order behavior could indicate that the carboxylate or amine substituent is more readily oxidized than the $\mathrm{C}-\mathrm{H}$ bond, due to the electron-richness of the 
$\mathrm{NH}_{2}$ moiety (the $E_{1 / 2}$ of aniline is $0.66 \mathrm{~V}$ vs. $\mathrm{Fc}^{+/ 0}$ in $\mathrm{MeCN}$ ). ${ }^{8}$ The $\mathrm{CF}_{3}$-derivative possibly could show deviations from a second-order model because the relatively slow MS-CPET allows other processes such as nucleophilic attack of the carboxylate to be competitive. Oxidant/base incompatibility is a general challenge to performing these separated reactions. ${ }^{9}$ However, issues with both problematic derivatives can be circumvented by using the weaker ferrocenium oxidants, as these are less susceptible to nucleophilic attack by the carboxylate.
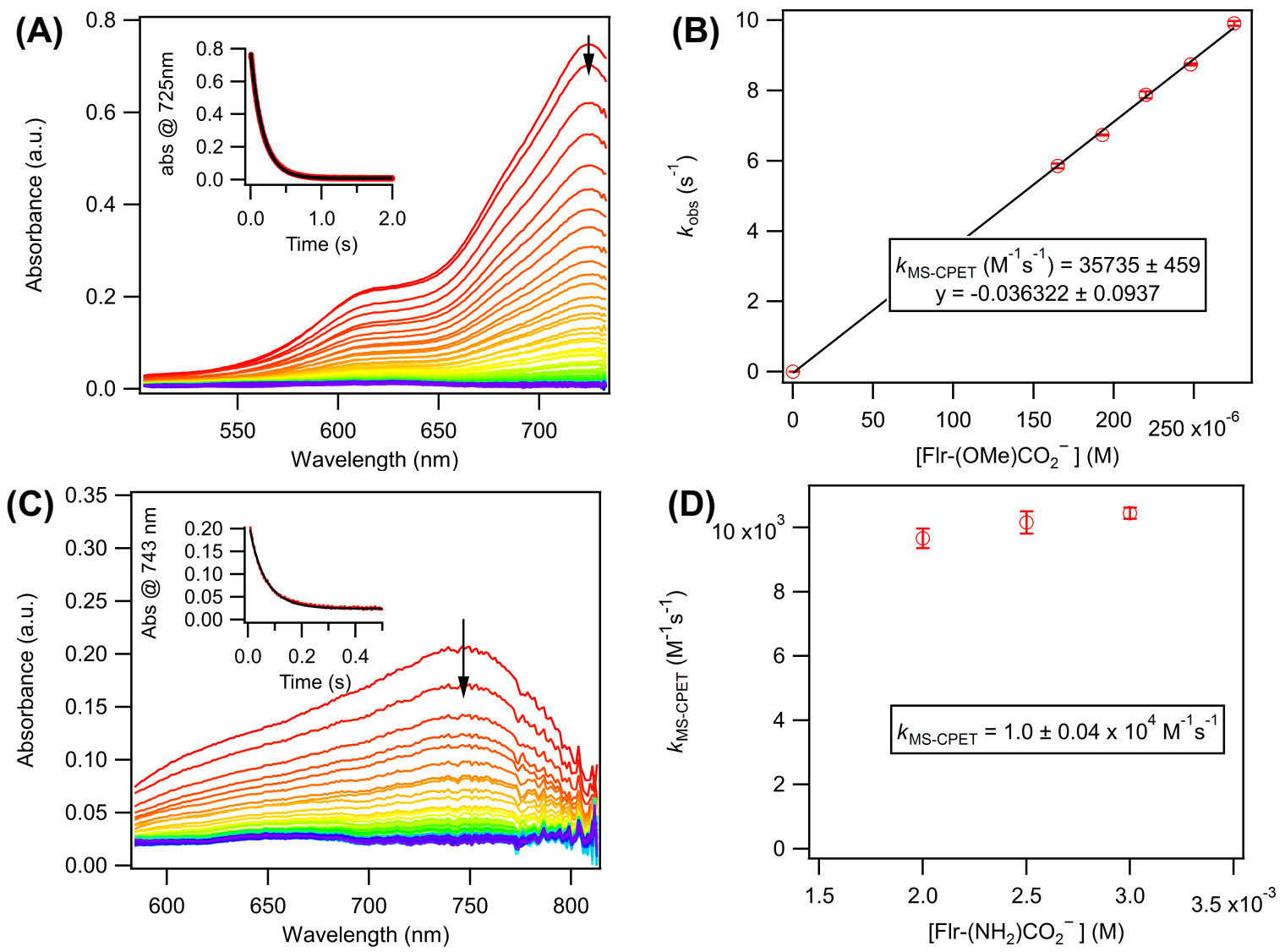

Figure S3.1. Representative data from stopped-flow experiments following (A-B) the oxidation of Flr(OMe) $\mathrm{CO}_{2}{ }^{-}$using $\mathbf{N}^{\bullet+}$ (Arome) 3 ; and (C-D) the oxidation of $\mathrm{F} \operatorname{lr}\left(\mathrm{NH}_{2}\right) \mathrm{CO}_{2}{ }^{-}$using $\mathbf{F e C p} * \mathbf{C p}^{+}$. (A) Evolution of spectra as $\mathbf{N}^{\cdot+}$ (Arome)3 reacts over time. (B) A plot of the pseudo first order rate constant $k_{\text {obs }}$ vs. [Flr(OMe) $\mathrm{CO}_{2}^{-}$] gives the second-order rate constant as the slope. (C) Evolution of spectra as $\mathbf{F e C p} * \mathbf{C p}^{+}$reacts over time. (D) A plot of the second order rate constant vs. $\left[\mathrm{Fl}\left(\mathrm{NH}_{2}\right) \mathrm{CO}_{2}^{-}\right]$. The average of the 3 data points yields the second-order rate constant and standard deviation.

\subsection{Tabulated values for $\Delta G^{\circ}$ rxn and $\log \left(K_{\text {eq }}\right)$ values with $\log \left(k_{\text {MS-CPET }}\right)$}

$k_{2}$ values were measured as described in the previous section. Then, $k_{\mathrm{MS} \text {-CPET was calculated as }}$ $k_{\mathrm{MS}-\mathrm{CPET}}=k_{2} / 2$ because 2 eq of oxidant are consumed in each step to form the lactone product. The value for $\Delta G^{\circ}{ }_{\text {rxn }}$ for $\mathrm{F} \operatorname{lr}(\mathrm{H}) \mathrm{CO}_{2}{ }^{-}$with $\mathrm{FeCp}^{*}{ }_{2}{ }^{+}$was previously reported to be about isoergic $\left(\Delta G^{\circ}{ }_{\text {rxn }}\right.$ $\left.\sim 0 \mathrm{kcal} \mathrm{mol}^{-1}\right) .{ }^{4}$ All values are then set relative to this based on the change in oxidant $E_{1 / 2}$ and $\mathrm{p} K_{\mathrm{a}}$ of the internal carboxylate. 
Table S3.1. Reactions of Flr $\left(\mathrm{NH}_{2}\right) \mathrm{CO}_{2}{ }^{-}$with oxidants.

\begin{tabular}{|c|c|c|c|c|c|c|}
\hline Ox & $E_{1 / 2}(\mathrm{~V})^{a}$ & $\Delta G^{\circ}{ }^{b}{ }^{b}$ & $\log \left(K_{\mathrm{eq}}\right)^{c}$ & $k_{2}\left(\mathbf{M}^{-1} \mathbf{s}^{-1}\right)^{d}$ & $\begin{array}{l}k_{\text {MS-CPET }} \\
\left(M^{-1} \mathbf{s}^{-1}\right) \underline{\mathrm{e}}\end{array}$ & $\log \left(k_{\text {MS-CPET }}\right)$ \\
\hline $\mathrm{FeCp}_{2}{ }^{+}$ & 0 & -13.5 & 9.14 & $5.20 \mathrm{E}+04$ & $2.60 \mathrm{E}+04$ & 4.41 \\
\hline $\mathrm{FeCp} * \mathrm{Cp}^{+}$ & -0.27 & -7.2 & 4.52 & $1.00 \mathrm{E}+04$ & $5.00 \mathrm{E}+03$ & 3.70 \\
\hline $\mathrm{FeCp}_{2}{ }^{+}$ & -0.48 & -2.4 & 0.93 & $1.30 \mathrm{E}+03$ & $6.50 \mathrm{E}+02$ & 2.81 \\
\hline \multicolumn{7}{|c|}{ 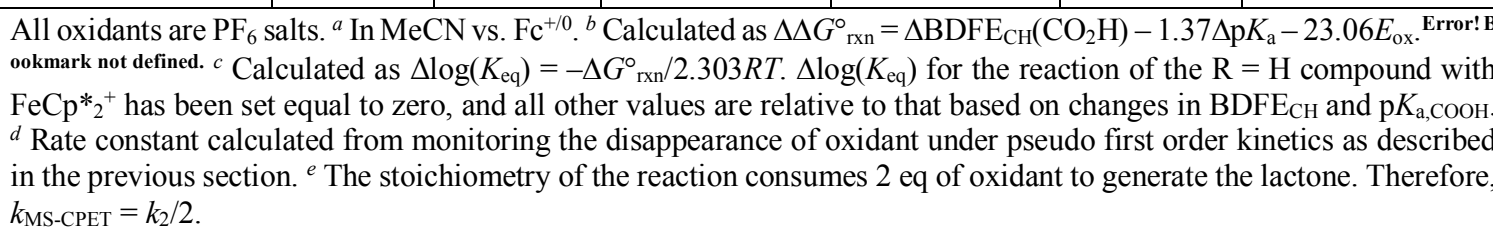 } \\
\hline
\end{tabular}

Table S3.2. Reactions of $\mathrm{Fl}(\mathrm{OMe}) \mathrm{CO}_{2}^{-}$with oxidants.

\begin{tabular}{|c|c|c|c|c|c|c|}
\hline $\mathbf{O x}$ & $E_{1 / 2}(\mathrm{~V})^{a}$ & $\Delta G^{\circ}{ }_{\mathrm{rxn}}^{b}$ & $\log \left(K_{\mathrm{eq}}\right)^{c}$ & $k_{2}\left(\mathbf{M}^{-1} \mathbf{s}^{-1}\right)^{d}$ & $\begin{array}{l}k_{\text {MS-CPET }} \\
\left(\mathbf{M}^{-1} \mathbf{s}^{-1}\right)^{\underline{e}}\end{array}$ & $\log \left(k_{\text {MS-CPET }}\right)$ \\
\hline $\mathrm{N}\left(\mathrm{Ar}_{\mathrm{Br}}\right)_{3}{ }^{+}$ & 0.67 & -27.7 & 20.53 & $2.60 \mathrm{E}+06$ & $1.30 \mathrm{E}+06$ & 6.11 \\
\hline $\mathrm{N}\left(\mathrm{Ar}_{\mathrm{OMe}}\right)\left(\mathrm{Ar}_{\mathrm{Br}}\right) 2^{\bullet+}$ & 0.48 & -23.3 & 17.28 & $1.60 \mathrm{E}+05$ & $8.00 \mathrm{E}+04$ & 4.90 \\
\hline $\mathrm{N}\left(\mathrm{Ar}_{\mathrm{OMe}}\right)_{2}\left(\mathrm{Ar}_{\mathrm{Br}}\right)^{\cdot+}$ & 0.32 & -19.6 & 14.55 & $6.30 \mathrm{E}+04$ & $3.15 \mathrm{E}+04$ & 4.50 \\
\hline $\mathrm{N}\left(\mathrm{Ar}_{\mathrm{OMe}}\right)_{3}{ }^{\cdot+}$ & 0.16 & -15.9 & 11.81 & $3.60 \mathrm{E}+04$ & $1.80 \mathrm{E}+04$ & 4.26 \\
\hline $\mathrm{FeCp}_{2}{ }^{+}$ & 0 & -12.3 & 9.08 & $5.00 \mathrm{E}+03$ & $2.50 \mathrm{E}+03$ & 3.40 \\
\hline $\mathrm{FeCp}^{*} \mathrm{Cp}^{+}$ & -0.27 & -6.0 & 4.47 & $1.00 \mathrm{E}+03$ & $5.00 \mathrm{E}+02$ & 2.70 \\
\hline $\mathrm{FeCp}_{2}^{*}{ }^{+}$ & -0.48 & -1.2 & 0.88 & $1.10 \mathrm{E}+02$ & $5.50 \mathrm{E}+01$ & 1.74 \\
\hline \multicolumn{7}{|c|}{ 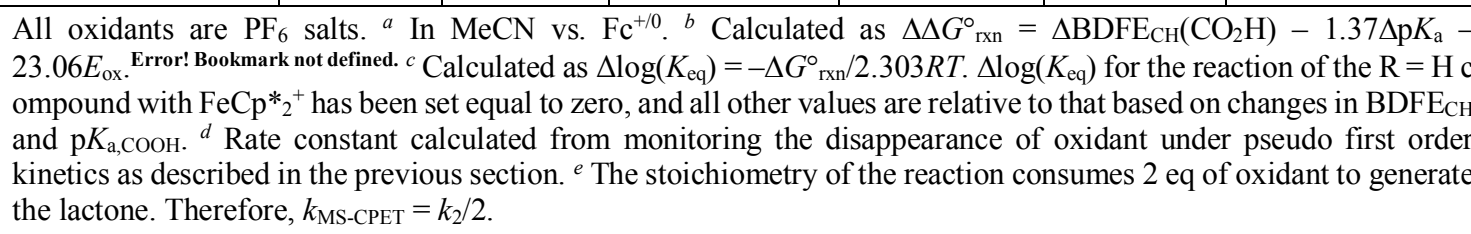 } \\
\hline
\end{tabular}

Table S3.3. Reactions of $\mathrm{Flr}(\mathrm{H}) \mathrm{CO}_{2}^{-}$with oxidants (some values previously reported in ref. 4).

\begin{tabular}{|c|c|c|c|c|c|c|}
\hline Ox & $E_{1 / 2}(\mathbf{V})^{a}$ & $\Delta G^{\circ}{ }_{\mathrm{rxn}}^{b}$ & $\log \left(K_{\mathrm{eq}}\right)^{c}$ & $k_{2}\left(\mathbf{M}^{-1} \mathbf{s}^{-1}\right)^{d}$ & $\begin{array}{l}k_{\text {MS-CPET }} \\
\left(M^{-1} \mathbf{s}^{-1}\right) \underline{\text { e }}\end{array}$ & $\log \left(k_{\text {MS-CPET }}\right)$ \\
\hline $\mathrm{N}\left(\mathrm{Ar}_{\mathrm{Br}}\right)_{3}{ }^{\cdot+}$ & 0.67 & -26.5 & 19.65 & $7.20 \mathrm{E}+05$ & $3.60 \mathrm{E}+05$ & 5.56 \\
\hline $\mathrm{N}\left(\mathrm{Ar}_{\mathrm{OMe}}\right)\left(\mathrm{Ar}_{\mathrm{Br}}\right) 2^{\cdot+}$ & 0.48 & -22.1 & 16.41 & $5.40 \mathrm{E}+04$ & $2.70 \mathrm{E}+04$ & 4.43 \\
\hline
\end{tabular}




\begin{tabular}{|c|c|c|c|c|c|c|}
\hline $\mathrm{N}\left(\mathrm{Ar}_{\mathrm{OMe}}\right)_{2}\left(\mathrm{Ar}_{\mathrm{Br}}\right)^{*+}$ & 0.32 & -18.4 & 13.67 & $1.90 \mathrm{E}+04$ & $9.50 \mathrm{E}+03$ & 3.98 \\
\hline $\mathrm{N}\left(\mathrm{Ar}_{\mathrm{OMe}}\right)_{3}{ }^{+}$ & 0.16 & -14.7 & 10.94 & $9.50 \mathrm{E}+03$ & $4.75 \mathrm{E}+03$ & 3.68 \\
\hline $\mathrm{FeCp}_{2}{ }^{+}$ & 0 & -11.0 & 8.20 & $1.90 \mathrm{E}+03$ & $9.50 \mathrm{E}+02$ & 2.98 \\
\hline $\mathrm{FeCp}^{*} \mathrm{Cp}^{+}$ & -0.27 & -4.8 & 3.59 & $3.80 \mathrm{E}+02$ & $1.90 \mathrm{E}+02$ & 2.28 \\
\hline $\mathrm{FeCp}^{*}{ }^{+}$ & -0.48 & 0.0 & 0.00 & $2.30 \mathrm{E}+01$ & $1.15 \mathrm{E}+01$ & 1.06 \\
\hline
\end{tabular}

All oxidants are $\mathrm{PF}_{6}$ salts. ${ }^{a}$ In $\mathrm{MeCN}$ vs. $\mathrm{Fc}^{+/ 0} .{ }^{b}$ Calculated as $\Delta \Delta G_{\mathrm{rxn}}^{\circ}=\Delta \mathrm{BDFE}_{\mathrm{CH}}\left(\mathrm{CO}_{2} \mathrm{H}\right)-1.37 \Delta \mathrm{p} K_{\mathrm{a}}-$ $23.06 E_{\text {ox. }}$ Error! Bookmark not defined. $c$ Calculated as $\Delta \log \left(K_{\text {eq }}\right)=-\Delta G^{\circ}{ }_{\text {rxn }} / 2.303 R T . \Delta \log \left(K_{\text {eq }}\right)$ for the reaction of the R $=\mathrm{H} \mathrm{c}$ ompound with $\mathrm{FeCp}{ }_{2}{ }_{2}$ has been set equal to zero, and all other values are relative to that based on changes in $\mathrm{BDFE} \mathrm{CH}_{\mathrm{CH}}$ and $\mathrm{p} K_{\mathrm{a}, \mathrm{COOH}}{ }^{d}$ Rate constant calculated from monitoring the disappearance of oxidant under pseudo first order kinetics as described in the previous section. ${ }^{e}$ The stoichiometry of the reaction consumes 2 eq of oxidant to generate the lactone. Therefore, $k_{\mathrm{MS}-\mathrm{CPET}}=k_{2} / 2$.

Table S3.4. Reactions of $\mathrm{Flr}\left(\mathrm{CF}_{3}\right) \mathrm{CO}_{2}^{-}$with oxidants.

\begin{tabular}{|c|c|c|c|c|c|c|}
\hline $\mathbf{O x}$ & $E_{1 / 2}(\mathrm{~V})^{a}$ & $\Delta G_{\mathrm{rxn}}^{\mathrm{o}}$ & $\log \left(K_{\mathrm{eq}}\right)^{c}$ & $k_{2}\left(\mathbf{M}^{-1} \mathbf{s}^{-1}\right)^{d}$ & $\begin{array}{l}k_{\mathrm{MS}-\mathrm{CPET}} \\
\left(\mathbf{M}^{-1} \mathbf{s}^{-1}\right) \underline{\mathrm{e}}\end{array}$ & $\log \left(k_{\text {MS-CPET }}\right)$ \\
\hline $\mathrm{N}\left(\mathrm{Ar}_{\mathrm{OMe}}\right)_{2}\left(\mathrm{Ar}_{\mathrm{Br}}\right)^{\cdot+}$ & 0.32 & -15.5 & 11.50 & $4.40 \mathrm{E}+03$ & $2.20 \mathrm{E}+03$ & 3.34 \\
\hline $\mathrm{N}\left(\mathrm{Ar}_{\mathrm{OMe}}\right)_{3}{ }^{\cdot+}$ & 0.16 & -11.8 & 8.77 & $1.10 \mathrm{E}+03$ & $5.50 \mathrm{E}+02$ & 2.74 \\
\hline $\mathrm{FeCp}_{2}{ }^{+}$ & 0 & -8.1 & 6.03 & $1.90 \mathrm{E}+02$ & $9.50 \mathrm{E}+01$ & 1.98 \\
\hline $\mathrm{FeCp} * \mathrm{Cp}^{+}$ & -0.27 & -1.9 & 1.42 & $3.00 \mathrm{E}+01$ & $1.50 \mathrm{E}+01$ & 1.18 \\
\hline
\end{tabular}

All oxidants are $\mathrm{PF}_{6}$ salts. ${ }^{a}$ In $\mathrm{MeCN}$ vs. $\mathrm{Fc}^{+/ 0} .{ }^{b}$ Calculated as $\Delta \Delta G_{\mathrm{rxn}}^{\circ}=\Delta \mathrm{BDFE}_{\mathrm{CH}}\left(\mathrm{CO}_{2} \mathrm{H}\right)-1.37 \Delta \mathrm{p} K_{\mathrm{a}}-$

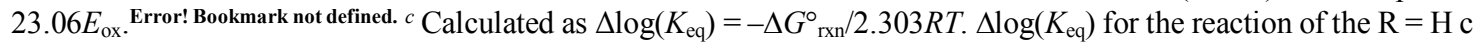
ompound with $\mathrm{FeCp}_{2}{ }_{2}^{+}$has been set equal to zero, and all other values are relative to that based on changes in $\mathrm{BDFE}_{\mathrm{CH}}$ and $\mathrm{p} K_{\mathrm{a}, \mathrm{COOH}}{ }^{d}$ Rate constant calculated from monitoring the disappearance of oxidant under pseudo first order kinetics as described in the previous section. ${ }^{e}$ The stoichiometry of the reaction consumes 2 eq of oxidant to generate the lactone. Therefore, $k_{\mathrm{MS}-\mathrm{CPET}}=k_{2} / 2$. 


\subsection{Tabulated Brønsted $\alpha$ values with varying oxidants}

The value for the Brønsted $\alpha$ varies with the oxidant, as shown in Figure 1 in the main text. Table S3.5 shows how these values change with oxidant strength. Not every oxidant was measured with every substrate due to general oxidant/base incompatibilities described above. The number of data points is indicated in the far right column. The linear fits of these data are shown graphically in Figure S3.2 and given numerically in Table S3.5 (uncertainty from the fit of the lines in Figure S2.3).

Table S3.5. Brønsted $\alpha$ calculations with ferrocenium and aminium oxidants. The error is taken from the error of the linear fit shown in Figure S3.2.

\begin{tabular}{|c|c|}
\hline Oxidant & Brønsted $\boldsymbol{\alpha}$ \\
\hline $\mathrm{N}\left(\mathrm{Ar}_{\mathrm{Br}}\right)_{3}{ }^{++}$ & 0.64 \\
\hline $\mathrm{N}\left(\mathrm{Ar} \mathrm{OMe}_{\mathrm{O}}\right)\left(\mathrm{Ar} \mathrm{Br}_{\mathrm{Br}}\right)_{2}+{ }^{\cdot+}$ & 0.54 \\
\hline $\mathrm{N}\left(\mathrm{Ar}_{\mathrm{OMe}}\right)_{2}\left(\mathrm{Ar}_{\mathrm{Br}}\right)^{\cdot+}$ & $0.36 \pm 0.07$ \\
\hline $\mathrm{N}\left(\mathrm{Ar}_{\mathrm{OMe}}\right)_{3}{ }^{++}$ & $0.48 \pm 0.05$ \\
\hline $\mathrm{FeCp}_{2}{ }^{+}$ & $0.58 \pm 0.10$ \\
\hline $\mathrm{FeCp}^{*} \mathrm{Cp}^{+}$ & $0.61 \pm 0.09$ \\
\hline $\mathrm{FeCp}^{*}{ }^{+}$ & $0.99 \pm 0.12$ \\
\hline
\end{tabular}

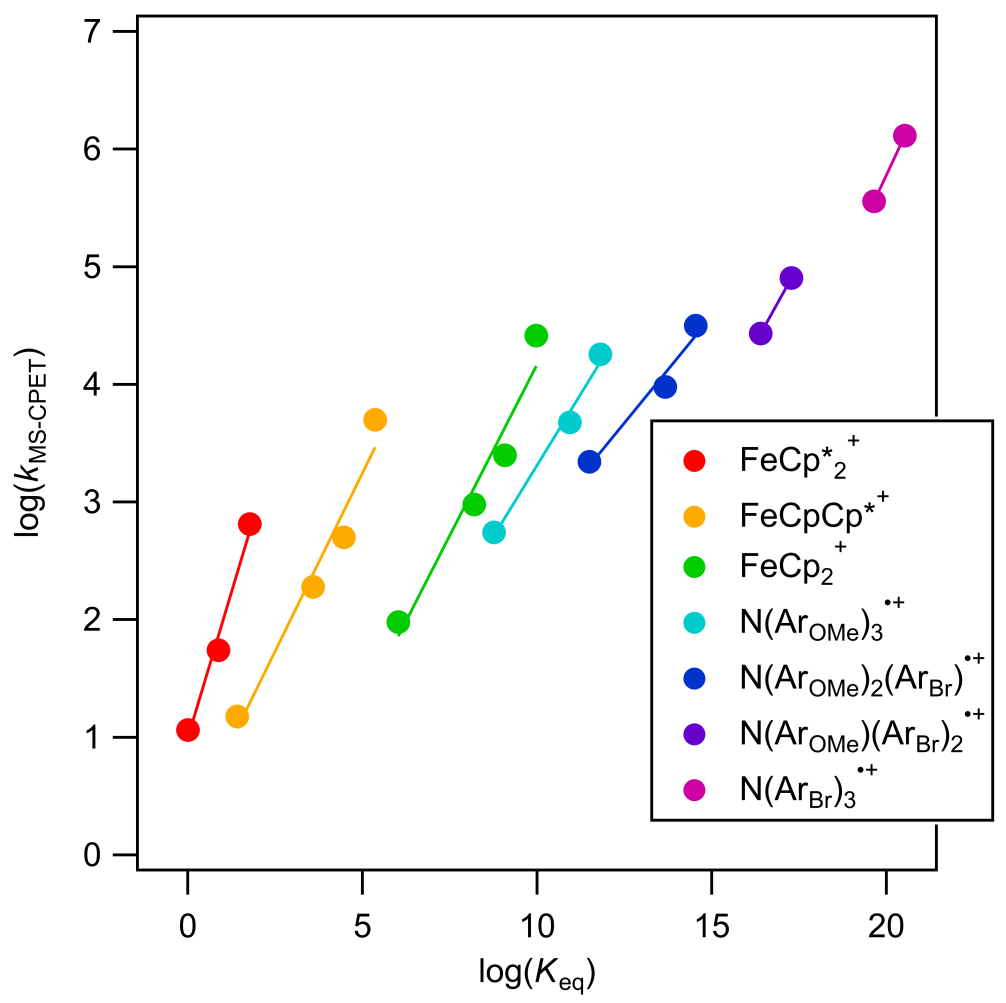

Figure S3.2. The Brønsted $\alpha$ with each oxidant are shown as the linear fits. 


\subsection{Temperature dependent kinetics}

Temperature dependence data was measured on a TgK double-mixing stopped flow using a Xenon light source and a Kineta Scan photodiode array detector at temperatures ranging from $-40-15^{\circ} \mathrm{C}$. All solutions were made in an $\mathrm{N}_{2}$-filled glovebox and loaded into gas tight syringes. Syringes were removed from the glovebox immeadiately before use. Stock solutions of $\mathrm{Flr}(\mathrm{R}) \mathrm{CO}_{2} \mathrm{H}$ were deprotonated with 0.9 equivalents of $\mathrm{TBAOH}$ in $\mathrm{MeOH}$ immediately before use. Serial dilutions of the stock material were made in $10 \mathrm{~mL}$ volumetric flasks to give solutions ranging from 10-30 eq of $\mathrm{F} \operatorname{lr}(\mathrm{R}) \mathrm{CO}_{2}{ }^{-}$relative to the oxidant. The appropriate amount of $\mathrm{MeOH}$ was added to the volumetric flask to make $[\mathrm{MeOH}]$ constant for all of the solutions of $\mathrm{Flr}(\mathrm{R}) \mathrm{CO}_{2}^{-}([\mathrm{MeOH}]=0.2 \%$ by volume after mixing in the stopped flow). The aminium oxidant $\mathrm{N}^{\cdot+}\left(\mathrm{PhOMe}_{3}\right.$ was used for all temperature dependence experiments, and the initial concentration of the oxidant was $15 \mu \mathrm{M}$.

Spectra were collected in photomultiplier mode at a single wavelength $(700 \mathrm{~nm})$, because it was observed that the aminium oxidants decay under the stopped-flow lamp in diode array mode. For each concentration of $\mathrm{F} \operatorname{lr}(\mathrm{R}) \mathrm{CO}_{2}^{-}$, the temperature was varied from -40 to $15^{\circ} \mathrm{C}$. Multiple data sets were collected at each temperature, and averaged before fitting to a single exponential to obtain a $k_{\text {obs }}$ value (Figure S3.3A). Plotting $k_{\text {obs }}$ vs. $\left[\mathrm{Flr}(\mathrm{R}) \mathrm{CO}_{2}{ }^{-}\right]$yields second-order rate constants at each temperature (Figure S3.3B). The second order-rate constants were then used to construct an Eyring plot (Figure S3.3C). A sample dataset is shown below for $\mathrm{F} \operatorname{lr}(\mathrm{OMe}) \mathrm{CO}_{2}^{-}$.

(A)

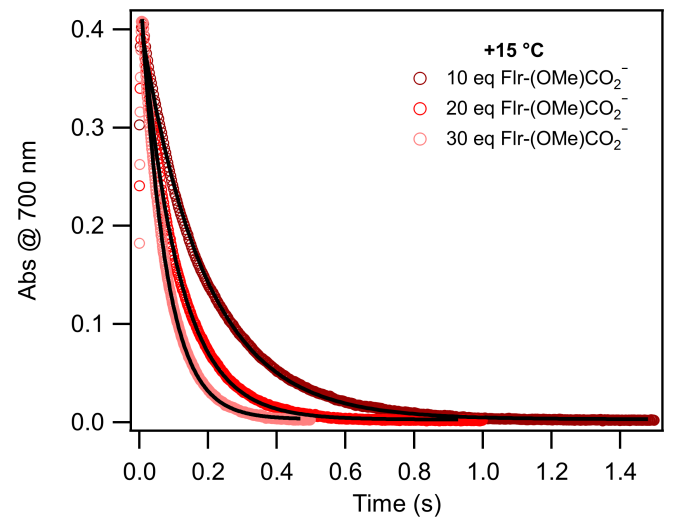

(B)

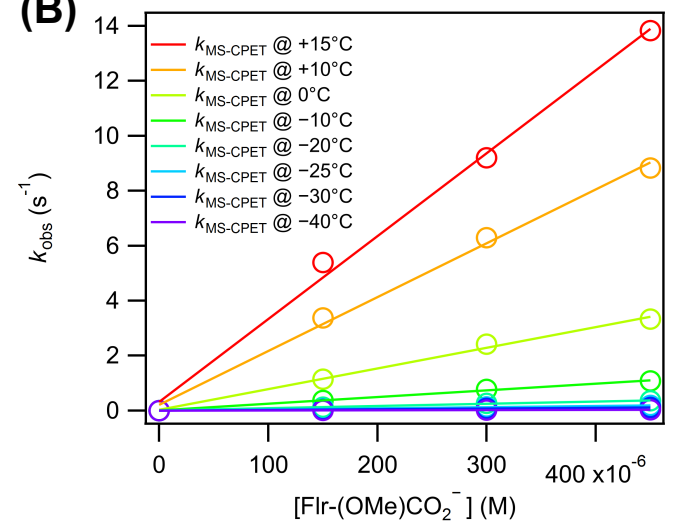

(C)

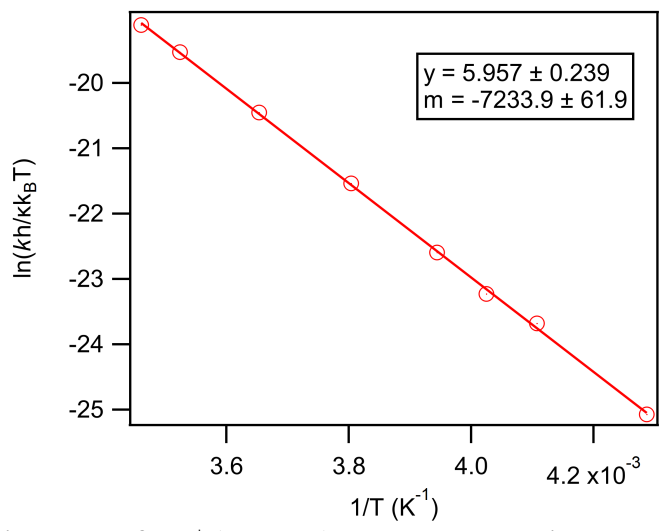

Figure S3.3. (A) The absorbance of $\mathrm{N}^{\bullet+}\left(\mathrm{ArOMe}_{3}\right)_{3}$ at $700 \mathrm{~nm}$ decays as it reacts with $\mathrm{Flr}(\mathrm{OMe}) \mathrm{CO}_{2}{ }^{-}$ $(150-450 \mu \mathrm{M})$. The traces fit well to a single exponential function. (B) The $k_{\text {obs }}$ value obtained from exponential fits of the absorbance vs. time data were plotted against $\left[\mathrm{Flr}(\mathrm{OMe}) \mathrm{CO}_{2}{ }^{-}\right]$to

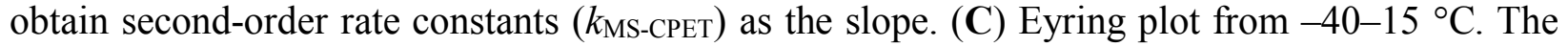
slope is equal to $-\Delta H^{\star} / \mathrm{R}$ and the $\mathrm{y}$-intercept is equal to $\Delta S^{\sharp} / \mathrm{RT}$. 


\section{DFT Calculations}

\subsection{Determination of $\mathrm{BDFE}_{\mathrm{CH}}\left(\mathrm{CO}_{2} \mathrm{H}\right)$ and $\mathrm{BDFE}_{\mathrm{CH}}\left(\mathrm{CO}_{2}{ }^{-}\right)$}

To determine the effect of substituents on the fluorenyl $\mathrm{C}-\mathrm{H}$ bond strength in $\operatorname{Fr}(\mathrm{R})\left(\mathrm{CO}_{2}{ }^{-}\right)$, relative $\mathrm{BDFE}_{\mathrm{CH}}\left(\mathrm{CO}_{2} \mathrm{H}\right)$ 's and $\mathrm{BDFE} \mathrm{CH}\left(\mathrm{CO}_{2}^{-}\right)$'s were determined for the fluorenyl $\mathrm{C}-\mathrm{H}$ bond of each substrate. The $\mathrm{BDFE}_{\mathrm{CH}}\left(\mathrm{CO}_{2} \mathrm{H}\right)$ 's were calculated by performing geometry optimizations on the carboxylic acid $\operatorname{Flr}(\mathrm{R})\left(\mathrm{CO}_{2} \mathrm{H}\right)$ and carboxylic acid radical $\mathrm{Flr}(\mathrm{C} \bullet)(\mathrm{R})\left(\mathrm{CO}_{2} \mathrm{H}\right)$ species of each substrate. The $\mathrm{BDFE}_{\mathrm{CH}}\left(\mathrm{CO}_{2}^{-}\right)$'s were calculated by performing geometry optimizations on the carboxylate $\mathrm{F} \operatorname{lr}(\mathrm{R})\left(\mathrm{CO}_{2}^{-}\right)$and carboxylate radical $\operatorname{Fr}(\mathrm{C} \bullet)(\mathrm{R})\left(\mathrm{CO}_{2}^{-}\right)$species of each substrate. The free energy of reaction $\left(\Delta G^{\circ}\right)$ for hydrogen atom transfer between the parent substrate and a second substrate was then determined for each compound. The $\Delta G^{0}$ was obtained by subtracting the free energy of formation $\left(\triangle G_{\mathrm{f}}\right)$ of reactants from products according to the following equations.

$$
R^{1}(\mathrm{C}-\mathrm{H}) \mathrm{CO}_{2} \mathrm{H}+R^{2}(\mathrm{C} \bullet) \mathrm{CO}_{2} \mathrm{H} \rightleftharpoons R^{1}(\mathrm{C} \bullet) \mathrm{CO}_{2} \mathrm{H}+R^{2}(\mathrm{C}-\mathrm{H}) \mathrm{CO}_{2} \mathrm{H}
$$

$$
\begin{aligned}
& \Delta G^{o}= \\
& \quad\left[\Delta G_{f}\left(R^{1}(\mathrm{C} \bullet) \mathrm{CO}_{2} \mathrm{H}\right)+\Delta G_{f}\left(R^{2}(\mathrm{C}-\mathrm{H}) \mathrm{CO}_{2} \mathrm{H}\right)\right]-\left[\Delta G_{f}\left(R^{1}(\mathrm{C}-\mathrm{H}) \mathrm{CO}_{2} \mathrm{H}\right)+R^{2}(\mathrm{C} \bullet) \mathrm{CO}_{2} \mathrm{H}\right] \\
& \Delta G^{o}=B D F E_{2}-B D F E_{1}
\end{aligned}
$$

Table S4.1. DFT calculated relative $\mathrm{BDFE}_{\mathrm{CH}}\left(\mathrm{CO}_{2} \mathrm{H}\right)$. The $\triangle \mathrm{BDFE}=\mathrm{BDFE}\left(\mathrm{Fl}(\mathrm{R}) \mathrm{CO}_{2} \mathrm{H}\right)-$ $\operatorname{BDFE}\left(\operatorname{Flr}(\mathrm{H}) \mathrm{CO}_{2} \mathrm{H}\right)$.

\begin{tabular}{|c|c|}
\hline Substrate & $\begin{array}{c}\Delta \text { BDFE } \\
\left(\mathrm{kcal} \mathrm{mol}^{-1}\right)\end{array}$ \\
\hline $\mathrm{Flr}(\mathrm{H}) \mathrm{CO}_{2}^{-}$ & 0 \\
\hline $\mathrm{Flr}\left(\mathrm{CF}_{3}\right) \mathrm{CO}_{2}^{-}$ & +0.83 \\
\hline $\mathrm{Flr}(\mathrm{OMe}) \mathrm{CO}_{2}^{-}$ & +0.22 \\
\hline $\mathrm{Flr}\left(\mathrm{NH}_{2}\right) \mathrm{CO}_{2}^{-}$ & -0.06 \\
\hline
\end{tabular}

$$
\begin{aligned}
& \begin{array}{|c|c|}
\hline \text { Substrate } & \begin{array}{c}
\Delta \text { BDFE } \\
\text { (kcal mol }^{-1} \text { ) }
\end{array} \\
\hline \text { Flr( }(\mathrm{H}) \mathrm{CO}_{2} \mathrm{H} & 0 \\
\hline \mathrm{F} \operatorname{lr}\left(\mathrm{CF}_{3}\right) \mathrm{CO}_{2} \mathrm{H} & +1.70 \\
\hline \mathrm{Flr}\left(\mathrm{OMe}_{2}\right) \mathrm{CO}_{2} \mathrm{H} & -0.77 \\
\hline \mathrm{Flr}\left(\mathrm{NH}_{2}\right) \mathrm{CO}_{2} \mathrm{H} & -1.30 \\
\hline
\end{array} \\
& R^{1}(\mathrm{C}-\mathrm{H}) \mathrm{CO}_{2}^{-}+R^{2}(\mathrm{C} \bullet) \mathrm{CO}_{2}^{-} \rightleftharpoons R^{1}(\mathrm{C} \bullet) \mathrm{CO}_{2}^{-}+R^{2}(\mathrm{C}-\mathrm{H}) \mathrm{CO}_{2}^{-} \\
& \Delta G^{o}=\left[\Delta G_{f}\left(R^{1}(\mathrm{C} \bullet) \mathrm{CO}_{2}^{-}\right)+\Delta G_{f}\left(R^{2}(\mathrm{C}-\mathrm{H}) \mathrm{CO}_{2}^{-}\right)\right]-\left[\Delta G_{f}\left(R^{1}(\mathrm{C}-\mathrm{H}) \mathrm{CO}_{2}^{-}\right)+R^{2}(\mathrm{C} \bullet) \mathrm{CO}_{2}^{-}\right] \\
& \Delta G^{o}=B D F E_{2}-B D F E_{1}
\end{aligned}
$$

Table S4.2. DFT calculated relative $\mathrm{BDFE}_{\mathrm{CH}}\left(\mathrm{CO}_{2}^{-}\right)$. The $\triangle \mathrm{BDFE}=\mathrm{BDFE}\left(\mathrm{Flr}(\mathrm{R}) \mathrm{CO}_{2}^{-}\right)-$ $\mathrm{BDFE}\left(\mathrm{Flr}(\mathrm{H}) \mathrm{CO}_{2}^{-}\right)$. 


\subsection{Internal Reaction Coordinate Calculation for Intramolecular Proton Transfer in $\operatorname{Flr}(\mathrm{H}) \mathrm{CO}_{2}^{-}$}

The candidate transition state (TS) structure in section S5.25 was confirmed as the true transition state for intramolecular proton transfer by performing an internal reaction coordinate (IRC) calculation on the candidate TS (IRC described in section S5.26). The calculation was performed using B3LYP//def2-SVP and PCM solvent as acetonitrile. The force constants were calculated at the beginning of the calculation using the CalcFC keyword, and 50 steps each were taken in the forward and reverse directions from the transition state with step size of $0.1 \mathrm{Bohr}(\mathrm{N}=10)$.

The IRC calculation proceeded in the forward direction to give a product that is within $0.4 \mathrm{kcal}$ $\mathrm{mol}^{-1}$ of the independently optimized product structure. Optimization of the IRC product (def2SVP) gave a structure within $0.09 \mathrm{kcal} \mathrm{mol}^{-1}$ of the independently optimized product structure. In the backwards direction, the IRC gave a reactant that is within $1.5 \mathrm{kcal} \mathrm{mol}^{-1}$ of the independently optimized reactant structure. Optimization of the IRC reactant (def2-SVP) gave a structure within $0.06 \mathrm{kcal} \mathrm{mol}^{-1}$ of the independently optimized reactant structure.

These results confirm that the candidate TS in section S5.25 follows the internal reaction coordinate to give the optimized reactant and products for intramolecular proton transfer, confirming it as the true transition state.

The energy versus internal reaction coordinate plot is shown in Figure S4.1 A. The position of the TS on the $\mathrm{x}$-axis is set to 0 . Following the $\mathrm{x}$-axis to negative values proceeds towards the reactant, and following the $\mathrm{x}$-axis along positive values proceeds towards the product. To evaluate the extent of proton transfer and electronic reorganization at the TS, the distance between the the carboxylate oxygen and the fluorenyl proton and the sum of the CCC bond angles around the fluorenyl carbon were plotted against the internal reaction coordinate as shown in (Figure S4.1 B and C). The extent of proton transfer was taken as the distance between the carboxylate oxygen and fluorenyl proton. The distance begins at $1.78 \AA$ and ends at $1.01 \AA$. The extent of electronic reorganization was taken as sum of the CCC bond angles around the fluorenyl carbon. This sum is $341^{\circ}$ for the more tetrahedral, $s p^{3}$ carbon of the reactant, and is $358^{\circ}$ in the more planar, $s p^{2}$ carbon of the product. 
A
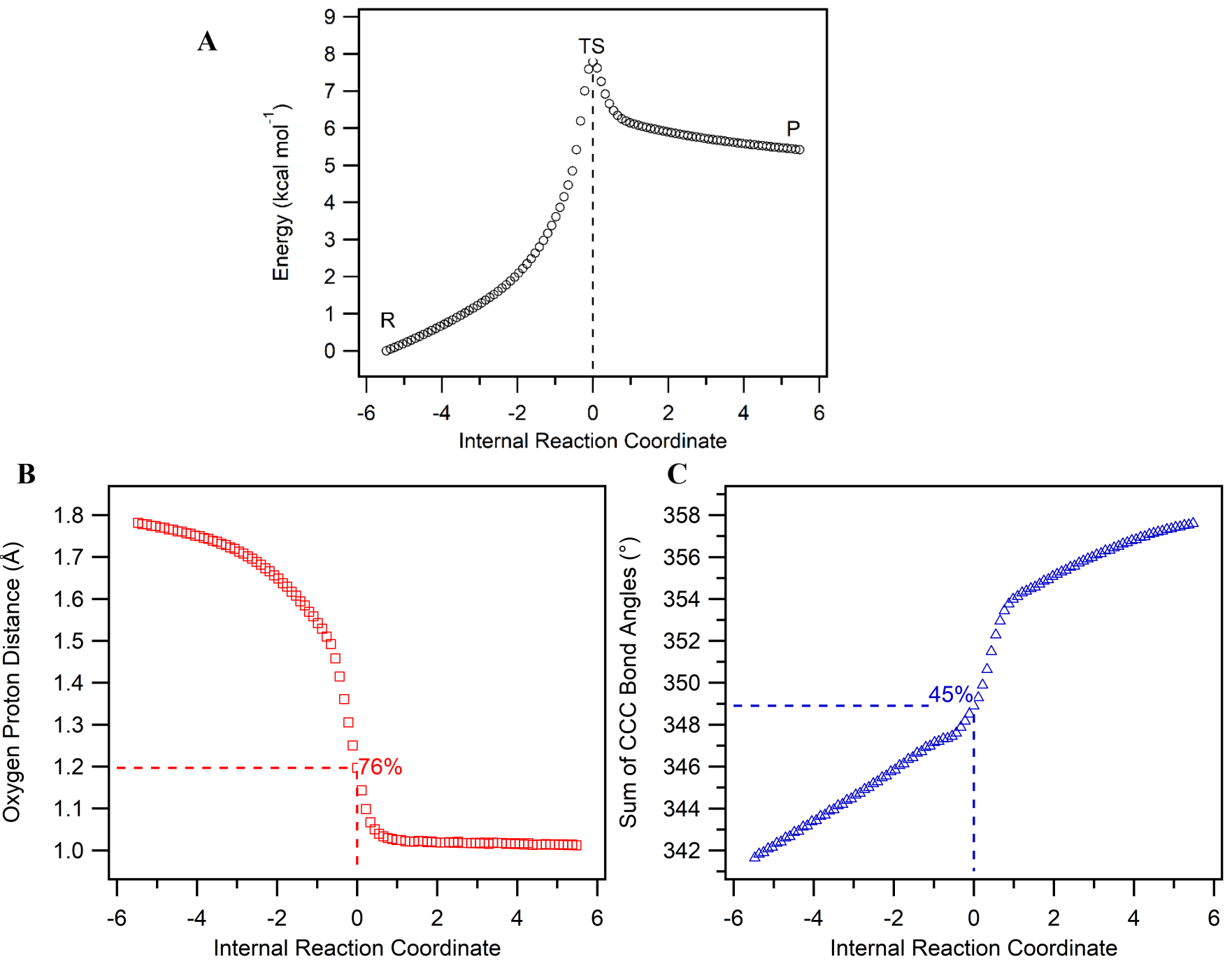

Figure S4.1. A. Potential energy surface from an IRC calculation for intramolecular proton transfer in $\mathrm{F} \operatorname{lr}(\mathrm{H}) \mathrm{CO}_{2}{ }^{-}$. The transition state (TS) is located at $\mathrm{x}=0$. B. Plot of the distance between the carboxylate oxygen and fluorenyl proton against the internal reaction coordinate. The distance has made $76 \%$ progress at the TS. C. Plot of the sum of the fluorenyl CCC bond angles against the internal reaction coordinate. The sum has made $45 \%$ progress at the TS.

The results show that the proton has made $76 \%$ progress from the fluorenyl carbon to the carboxylate oxygen, and the sum of the CCC bond angles has only made $45 \%$ progress towards the more planar product. This shows that proton transfer is much further ahead than electronic reorganization in the intramolecular proton transfer transition state. 


\subsection{Internal Reaction Coordinate Calculation for MS-CPET Between Flr( $\mathrm{H}) \mathrm{CO}_{2}{ }^{-}$and $\mathbf{N}^{\cdot+}\left(\mathrm{Ar}_{\mathrm{Br}}\right)_{3}$}

The candidate transition state (TS) structure for MS-CPET between $\mathrm{Flr}(\mathrm{H}) \mathrm{CO}_{2}{ }^{-}$and $\mathrm{N}^{\bullet+}\left(\mathrm{Ar}_{\mathrm{Br}}\right)_{3}$ in section S5.27 was confirmed as the true transition state by performing an internal reaction coordinate (IRC) calculation on the candidate TS (IRC described in section S5.28).

The potential energy surface for the substrate-oxidant complex was indeed found to be very flat. Substrate-oxidant orientations were found by placing the optimized isolated structures of substrate and oxidant in close proximity and re-optimizing. Multiple orientations were found that were very similar in energy. Two such substrate-oxidant complexes were submitted to potential energy surface scans along the proton transfer coordinate, locating an approximate transition state (TS) structure. This structure was then optimized to find a TS structure with one negative frequency and an intrinsic reaction coordinate (IRC) the led down to reactants and products. Finding such a TS was successful only for one of the two orientations screened, the one pictured in Error! $\mathbf{R}$ eference source not found..

The calculations were performed using B3LYP//def2-SVP and PCM solvent as acetonitrile. The force constants were calculated at the beginning of the calculation using the CalcFC keyword, and 100 steps each were taken in the forward and reverse directions from the transition state with step size of 0.05 Bohr $(\mathrm{N}=5)$.

The IRC calculation proceeded in the forward direction to give a product that is within $2.3 \mathrm{kcal}$ $\mathrm{mol}^{-1}$ of the independently optimized product structure. Optimization of the IRC product (def2SVP) gave a structure within $0.50 \mathrm{kcal} \mathrm{mol}^{-1}$ of the independently optimized product structure. In the backwards direction, the IRC gave a reactant that is within $1.2 \mathrm{kcal} \mathrm{mol}^{-1}$ of the independently optimized reactant structure. Optimization of the IRC reactant (def2-SVP) gave a structure within $0.90 \mathrm{kcal} \mathrm{mol}^{-1}$ of the independently optimized reactant structure.

These results confirm that the candidate TS in section S5.27 follows the internal reaction coordinate to give the optimized reactant and products for intramolecular proton transfer, confirming it as the true transition state.

The energy versus internal reaction coordinate plot is shown in Figure S4.2. The progress of proton transfer along the coordinate was taken as the distance between the fluorenyl proton and carboxylate oxygen, and the degree of electronic reorganization taken as the sum of the fluorenyl $\mathrm{CCC}$ bond angles. 


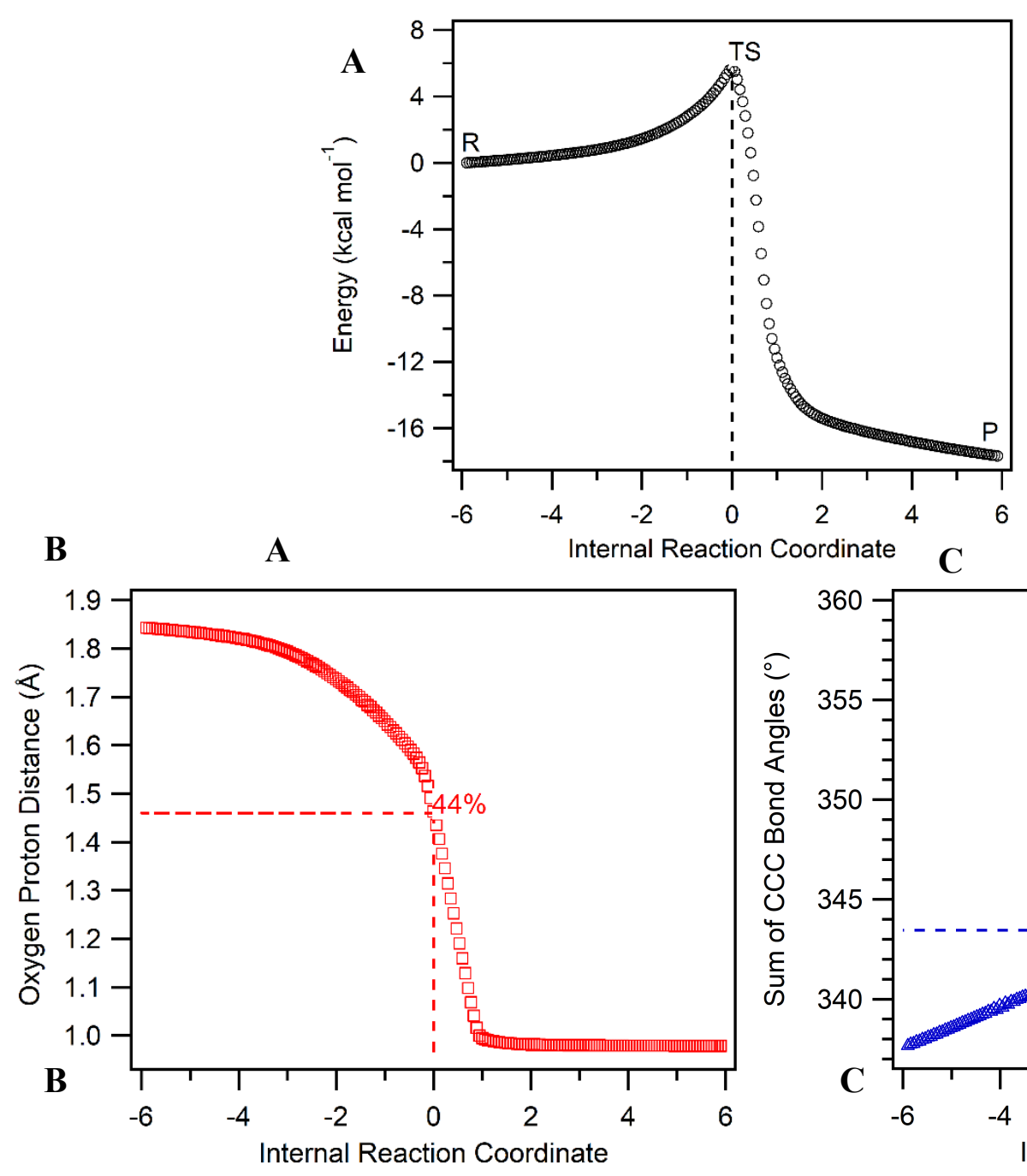

Figure S4.2. A. Potential energy surface from an IRC calculation for MS-CPET between $\mathrm{F} \operatorname{lr}(\mathrm{H}) \mathrm{CO}_{2}{ }^{-}$and $\mathrm{N}^{\cdot+}\left(\mathrm{Ar}_{\mathrm{Br}}\right)_{3}$. The transition state (TS) is located at $\mathrm{x}=0$. B. Plot of the distance between the carboxylate oxygen and fluorenyl proton against the internal reaction coordinate. The distance has made $44 \%$ progress at the TS. C. Plot of the sum of the fluorenyl CCC bond angles against the internal reaction coordinate. The sum has made $29 \%$ progress at the TS.

The results show that the proton has made $44 \%$ progress from the fluorenyl carbon to the carboxylate oxygen, and the sum of the CCC bond angles has only made $29 \%$ progress towards the more planar product. This shows that proton transfer is further ahead than electronic reorganization at the TS of MS-CPET. 


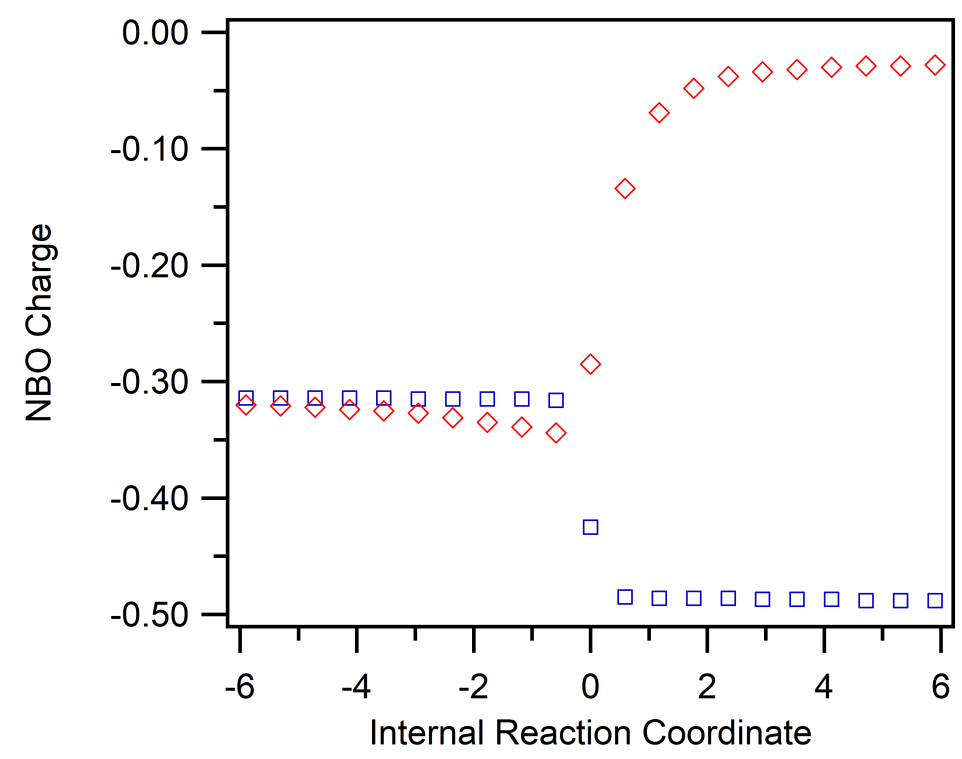

Figure S4.3. NBO charge versus internal reaction coordinate for the MS-CPET reaction between Flr $(\mathrm{H}) \mathrm{CO}_{2}^{-}$and $\mathrm{N}^{*}\left(\mathrm{Ar}_{\mathrm{Br}}\right)_{3}$. The charge for nitrogen is shown by blue squares and the charge for the fluorenyl carbon is shown by red diamonds.

To assess the extent of charge transfer throughout the reaction NBO calculations were performed along the internal reaction coordinate. The NBO charge of nitrogen starts at the value for isolated $\mathrm{N}^{\bullet+}\left(\mathrm{Ar}_{\mathrm{Br}}\right)_{3}(-0.315$ units), and stays constant up until the approximate TS. At the TS, the charge on the $\mathrm{N}$ becomes more negative, and remains at the value for isolated $\mathrm{N}\left(\mathrm{Ar}_{\mathrm{Br}}\right)_{3}(-0.489$ units). This is consistent with electron transfer occurring at the transition state but electronic reorganization in $\mathrm{F} \operatorname{lr}(\mathrm{H}) \mathrm{CO}_{2}^{-}$lagging significantly behind the transfer of the proton. The NBO charge of the fluorenyl carbon becomes more negative as the proton gets further away, then becomes abruptly more positive as the electron transfers at the transition state, then becomes more positive as electronic reorganization and proton transfer progress for the remainder of the reaction. These results are consistent with the interpretation presented above. 


\subsection{Comparison of Computational and Experimental $\Delta G^{\circ}$ rxn for the MS-CPET Reactions between $\mathrm{Flr}(\mathrm{H}) \mathrm{CO}_{2}{ }^{-}$and $\mathrm{N}^{\bullet+}\left(\mathrm{Ar}_{\mathrm{Br}}\right)_{3}$ and $\mathrm{Flr}(\mathrm{H}) \mathrm{CO}_{2}{ }^{-}$and $\mathrm{N}^{\bullet+}(\mathrm{Ph})_{3}$}

To determine a value for the computational $\Delta G^{\mathrm{o}}$, the difference in $\Delta \mathrm{G}_{\mathrm{f}}$ was taken between the reactants and products of the MS-CPET reaction between $\operatorname{Fr}(\mathrm{H}) \mathrm{CO}_{2}^{-}$and $\mathrm{N}^{\cdot+}\left(\mathrm{Ar}_{\mathrm{Br}}\right)_{3}$. The computational $\Delta G^{\mathrm{o}}$ was determined to be $-20.5 \mathrm{kcal} / \mathrm{mol}$.

The experimental $\Delta \mathrm{G}^{\circ}$ can be determined using the estimated fluorenyl BDFE $\mathrm{C}_{\mathrm{H}}$, the $\mathrm{p} K_{\mathrm{a}}$ of the $\mathrm{F} \operatorname{lr}(\mathrm{H}) \mathrm{CO}_{2}{ }^{-}$carboxylate, and the $E^{\circ}$ (vs. $\mathrm{Fc}^{+}$) of $\mathrm{N}^{\circ}\left(\mathrm{Ar}_{\mathrm{Br}}\right)_{3}$. These can be combined using Bordwell's equation to give an "effective BDFE" (BDFE eff ). $\{$ Waidmann, 2012 \#10\} The difference between the fluorenyl $\mathrm{C}-\mathrm{H} \mathrm{BDFE} \mathrm{C}_{\mathrm{H}}$ and the BDFE $\mathrm{eff}_{\text {of }}$ the carboxylate and $\mathrm{N}^{\bullet+}\left(\mathrm{Ar}_{\mathrm{Br}}\right)_{3}$ give the experimental $\Delta G^{0}=-25 \pm 2 \mathrm{kcal} / \mathrm{mol}$ as shown in the equations below, showing good agreement.

$$
\begin{aligned}
& \text { Fluorenyl } C-H B D F E=74 \pm 2 \mathrm{kcal} / \mathrm{mol} \\
& p K_{a}\left(\mathrm{FlrHCO}_{2} \mathrm{H}\right)=20.9 \\
& E^{0}\left(\left[N^{\bullet+}\left(A r_{B r}\right)_{3}\right]^{+/ 0}\right)=0.67 V \text { vs. } F C^{+/ 0} \\
& B D F E_{\text {eff }}=1.37 * p K_{a}+23.07 * E^{0}+54.9 \\
& B D F E_{\text {eff }}=1.37 * 20.9+23.07 * 0.67+54.9=99 \mathrm{kcal} / \mathrm{mol} \\
& \text { Experimental } \Delta G_{r x n}=B D F E_{C-H}-B D F E_{e f f}=74-99=-25 \pm 2 \mathrm{kcal} / \mathrm{mol} \\
& \text { Computational } \Delta G_{r x n}=\Delta G_{f}(\text { Products })-\Delta G_{f}(\text { Reactants })=-20.5 \mathrm{kcal} / \mathrm{mol}
\end{aligned}
$$

This same procedure was carried out to determine the computational $\Delta G^{\mathrm{o}}$ for the MS-CPET reaction between $\mathrm{F} \operatorname{lr}(\mathrm{H}) \mathrm{CO}_{2}{ }^{-}$and $\mathrm{N}^{\cdot+}(\mathrm{Ph})_{3}$.

Computational $\Delta G_{r x n}=\Delta G_{f}($ Products $)-\Delta G_{f}($ Reactants $)=-18.4 \mathrm{kcal} / \mathrm{mol}$ 


\subsection{Internal Reaction Coordinate Calculation for MS-CPET between $\mathrm{Flr}(\mathrm{H}) \mathrm{CO}_{2}{ }^{-}$and $\mathbf{N}^{\bullet+}(\mathbf{P h})_{3}$}

To verify that the candidate transition state of MS-CPET between $\mathrm{Flr}(\mathrm{H}) \mathrm{CO}_{2}{ }^{-}$and $\mathrm{N}^{\bullet+}(\mathrm{Ph})_{3}$ is a true transition state, an IRC calculation was performed in the same fashion as described in section S4.3. The transition state and IRC calculations can be found in sections S5.29 and S5.30.

The IRC calculation proceeded in the forward direction to give a product that is within $2.1 \mathrm{kcal}$ $\mathrm{mol}^{-1}$ of the independently optimized product structure. Optimization of the IRC product (def2SVP) gave a structure within $1.1 \mathrm{kcal} \mathrm{mol}^{-1}$ of the independently optimized product structure. In the backwards direction, the IRC gave a reactant that is within $1.4 \mathrm{kcal} \mathrm{mol}^{-1}$ of the independently optimized reactant structure. Optimization of the IRC reactant (def2-SVP) gave a structure within $0.03 \mathrm{kcal} \mathrm{mol}^{-1}$ of the independently optimized reactant structure.

These results confirm that the candidate TS in section S5.29 follows the internal reaction coordinate to give the optimized reactant and products for intramolecular proton transfer, confirming it as the true transition state.

The energy versus internal reaction coordinate plot is shown in Figure S4.4. The progress of proton transfer along the coordinate was taken as the distance between the fluorenyl proton and carboxylate oxygen, and the degree of electronic reorganization taken as the sum of the fluorenyl CCC bond angles. 
A

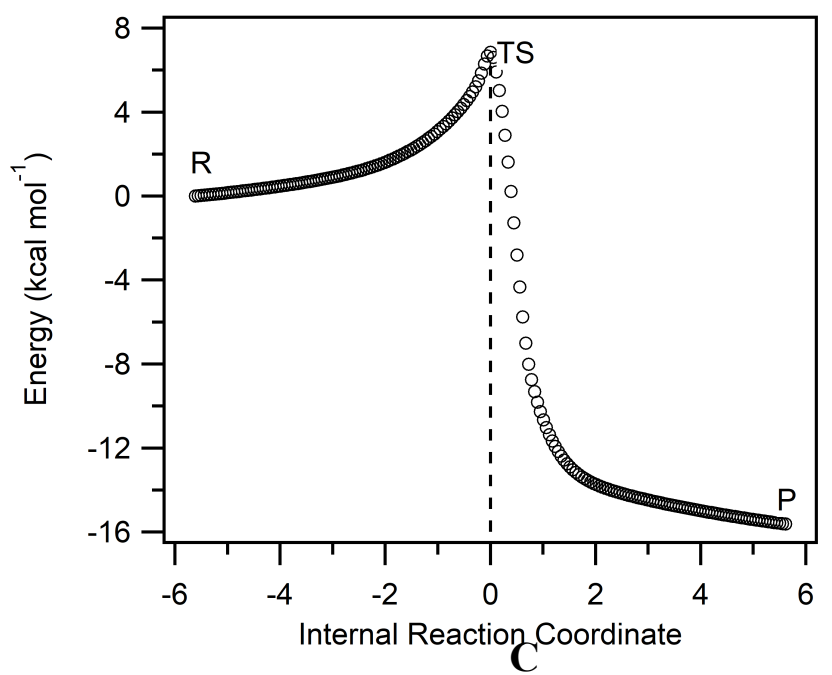

B
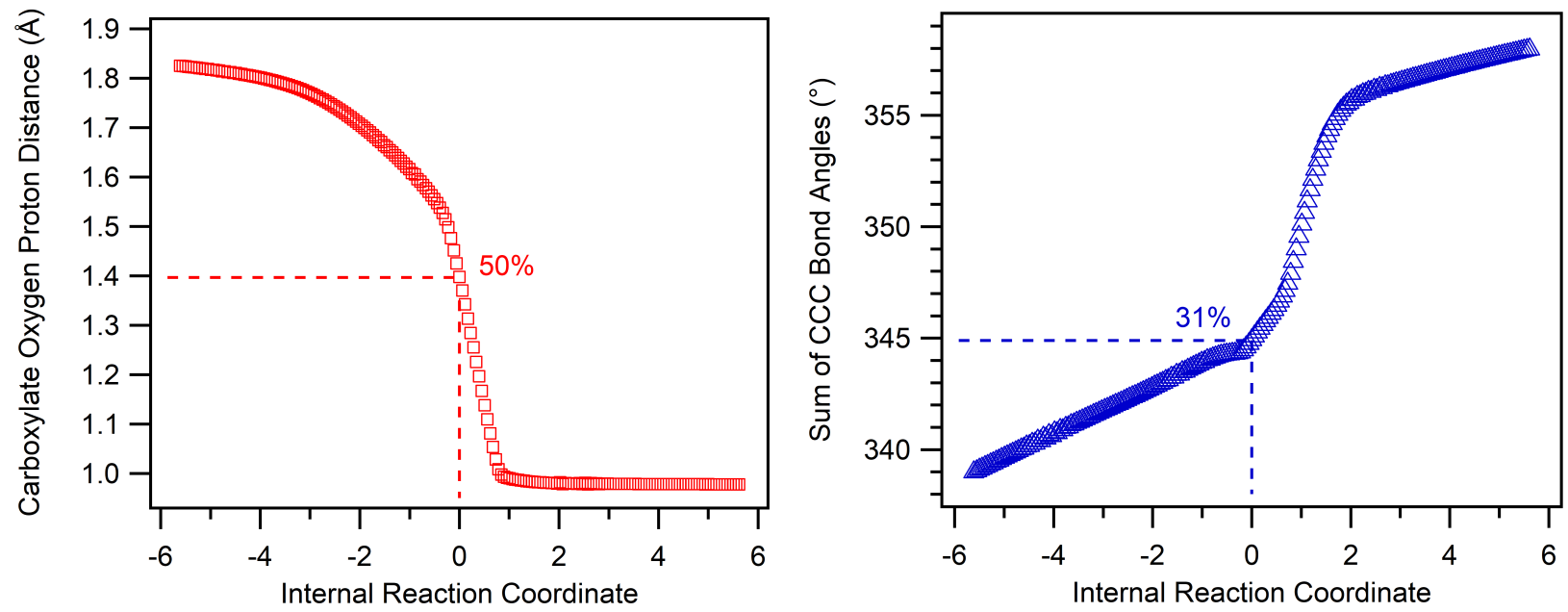

Figure S4.4. A. Potential energy surface from an IRC calculation for MS-CPET between $\mathrm{F} \operatorname{lr}(\mathrm{H}) \mathrm{CO}_{2}{ }^{-}$and $\mathrm{N}^{\cdot+}(\mathrm{Ph})_{3}$. The transition state $(\mathrm{TS})$ is located at $\mathrm{x}=0$. B. Plot of the distance between the carboxylate oxygen and fluorenyl proton against the internal reaction coordinate. The distance has made 50\% progress at the TS. C. Plot of the sum of the fluorenyl CCC bond angles against the internal reaction coordinate. The sum has made $31 \%$ progress at the TS.

The results show that the proton has made 50\% progress from the fluorenyl carbon to the carboxylate oxygen, and the sum of the CCC bond angles has only made $31 \%$ progress towards the more planar product. This shows that proton transfer is further ahead than electronic reorganization at the TS of MS-CPET. 


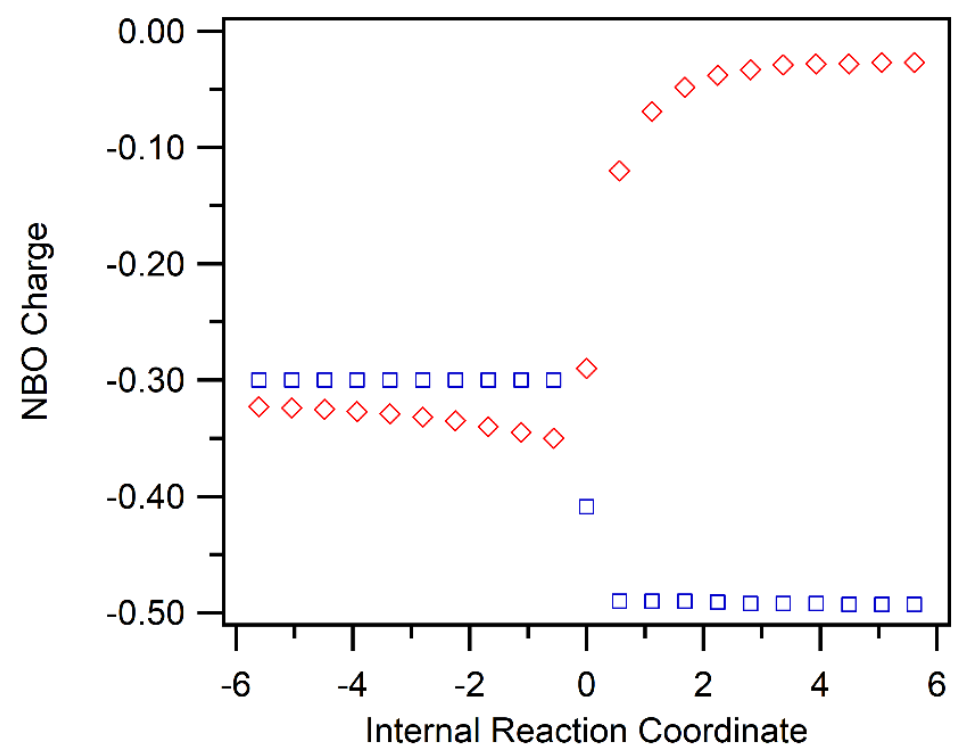

Figure S4.5. NBO charge versus internal reaction coordinate for the MS-CPET reaction between $\mathrm{F} \operatorname{lr}(\mathrm{H}) \mathrm{CO}_{2}{ }^{-}$and $\mathrm{N}^{*+}(\mathrm{Ph})_{3}$. The charge for nitrogen is shown by blue squares and the charge for the fluorenyl carbon is shown by red diamonds.

To assess the extent of charge transfer throughout the reaction NBO calculations were performed along the internal reaction coordinate. The NBO charge of nitrogen starts at the value for isolated $\mathrm{N}^{\cdot+}(\mathrm{Ph})_{3}(-0.30$ units), and stays constant up until the approximate TS. At the TS, the charge on the $\mathrm{N}$ becomes more negative, and remains at the value for isolated $\mathrm{N}(\mathrm{Ph})_{3}(-0.489$ units). This is consistent with electron transfer occurring at the transition state but electronic reorganization in Flr $(\mathrm{H}) \mathrm{CO}_{2}{ }^{-}$lagging significantly behind the transfer of the proton. The NBO charge of the fluorenyl carbon becomes more negative as the proton gets further away, then becomes abruptly more positive as the electron transfers at the transition state, then becomes more positive as electronic reorganization and proton transfer progress for the remainder of the reaction. These results are consistent with the interpretation presented above.

The MS-CPET reaction between $\mathrm{F} \operatorname{lr}(\mathrm{H}) \mathrm{CO}_{2}{ }^{-}$and $\mathrm{N}^{\bullet+}(\mathrm{Ph})_{3}$ is less downhill than the MS-CPET reaction between $\mathrm{F} \operatorname{lr}(\mathrm{H}) \mathrm{CO}_{2}^{-}$and $\mathrm{N}^{+}\left(\mathrm{Ar}_{\mathrm{Br}}\right)_{3}$. This oxidant is not stable in acetonitrile and has not been used in experiments with $\mathrm{F} \operatorname{lr}(\mathrm{H}) \mathrm{CO}_{2}^{-}$, but based on the difference in electron withdrawing character between bromine and hydrogen substituents this comparison makes chemical sense. As shown in section $\mathrm{S} 4.4$, the computational $\Delta G_{\mathrm{rxn}}$ with $\mathrm{N}^{\cdot+}(\mathrm{Ph})_{3}$ is $-18.4 \mathrm{kcal} / \mathrm{mol}$, or $2.1 \mathrm{kcal} / \mathrm{mol}$ more endoergic than the reaction with $\mathrm{N}^{\bullet+}\left(\mathrm{Ar}_{\mathrm{Br}}\right)_{3}$.

The purpose of comparing these two reactions computationally is to probe to what extent the proton transfer character and electronic reorganization character of the transition state depend on the driving force of the reaction. Because the reaction between $\mathrm{Flr}(\mathrm{H}) \mathrm{CO}_{2}{ }^{-}$and $\mathrm{N}^{\circ+}(\mathrm{Ph})_{3}$ is 2.1 $\mathrm{kcal} / \mathrm{mol}$ more endoergic than the reaction between $\mathrm{Flr}(\mathrm{H}) \mathrm{CO}_{2}{ }^{-}$and $\mathrm{N}^{\bullet+}\left(\mathrm{Ar} \mathrm{Br}_{3}\right.$ and both transition states are late in proton transfer and early in electronic reorganization character, this suggests that the driving force has a small effect on the relative extent of proton transfer and electronic reorganization in the transition state. 


\section{Coordinates of DFT Optimized Geometries}

\section{$5.1 \quad \mathrm{~F} \operatorname{Ir}\left(\mathrm{NH}_{2}\right) \mathrm{CO}_{2} \mathrm{H}$}

The columns on the first row represent the charge and multiplicity of the system. The columns on the second through final rows represent the atom label and Cartesian coordinates of that atom. All energies given after the coordinates are in Hartrees.

B3LYP/def2TZVP opt=tight int=ultrafine
$\begin{array}{ll}0 & 1\end{array}$
C $\quad 1.20411 \quad 3.49464 \quad 0.81971$
C $\quad 2.53662 \quad 3.19180 \quad 1.09916$
C $3.05383 \quad 1.93273 \quad 0.80880$
C $\quad 0.36587 \quad 2.54137 \quad 0.24148$
$\begin{array}{llll}\text { C } & 2.21741 & 0.97870 & 0.23465\end{array}$
$\begin{array}{llll}\text { C } & 0.18392 & 0.09297 & -0.69853\end{array}$
$\begin{array}{llll}\text { C } & 1.29247 & -0.95017 & -0.69610\end{array}$
C $2.47539 \quad-0.40631 \quad-0.16931$
C $3.63624 \quad-1.17243-0.09929$
C $\quad 3.60211 \quad-2.48668-0.55492$
$\begin{array}{llll}\text { C } & 1.26358 & -2.26065 & -1.14721\end{array}$
$\begin{array}{llll}\text { C } & 2.42585 & -3.02802 & -1.07315\end{array}$
H $3.17395 \quad 3.94348 \quad 1.54761$
$\begin{array}{llll}\mathrm{H} & 4.08944 & 1.70463 & 1.02891\end{array}$
H $\quad 4.55225 \quad-0.75835 \quad 0.30351$
H $4.49582 \quad-3.09588 \quad-0.50499$
H $\quad 0.35568 \quad-2.69617 \quad-1.54639$
H $2.41433 \quad-4.05325-1.42075$
C $\quad-1.11284 \quad-0.30352 \quad 0.00074$
C $\quad-2.38781 \quad 0.03202 \quad-0.49727$
$\begin{array}{llll}\text { C } & -3.51414 & -0.21977 & 0.30151\end{array}$
C $\quad-3.41215 \quad-0.83596 \quad 1.52872$
$\begin{array}{llll}\text { C } & -2.14937 & -1.20087 & 2.02612\end{array}$
$\begin{array}{llll}\text { C } & -1.02125 & -0.90747 & 1.25004\end{array}$
$\mathrm{H} \quad-4.48914 \quad 0.06398 \quad-0.07256$
H $\quad-4.30153 \quad-1.03998 \quad 2.11188$ 


$\begin{array}{llll}\mathrm{N} & -2.02903 & -1.86236 & 3.22589 \\ \mathrm{H} & -0.04205 & -1.14814 & 1.64628 \\ \mathrm{C} & -2.66064 & 0.67726 & -1.80976 \\ \mathrm{O} & -3.39819 & 1.62413 & -1.95640 \\ \mathrm{O} & -2.08109 & 0.14006 & -2.91333 \\ \mathrm{H} & 0.81684 & 4.47834 & 1.05315 \\ \mathrm{C} & 0.87774 & 1.28716 & -0.04858 \\ \mathrm{H} & -0.66827 & 2.78464 & 0.02963 \\ \mathrm{H} & -0.02921 & 0.36448 & -1.73484 \\ \mathrm{H} & -1.66658 & -0.70880 & -2.70649 \\ \mathrm{H} & -2.80071 & -1.79706 & 3.87015 \\ \mathrm{H} & -1.12504 & -1.85970 & 3.67048\end{array}$

Electronic Energy (0 K): -976.775876128

Enthalpy (298.150 K): -976.457552

Free Energy (298.150 K): -976.523458 


\section{$5.2 \operatorname{Flr}\left(\mathrm{NH}_{2}\right) \mathrm{CO}_{2}^{-}$}

B3LYP/def2TZVP opt=tight int=ultrafine
$-1 \quad 1$
C $\quad 1.53282 \quad 3.50213 \quad 0.49147$
C $2.84324 \quad 3.110110 .76799$
$\begin{array}{llll}\text { C } & 3.23830 & 1.78723 & 0.59145\end{array}$
C $\quad 0.59701 \quad 2.57626 \quad 0.03053$
$\begin{array}{llll}\text { C } & 2.30321 & 0.86049 & 0.13553\end{array}$
C $\quad 0.17353 \quad 0.08178 \quad-0.66584$
C $1.17980 \quad-1.05041-0.58192$
$\begin{array}{llll}\text { C } & 2.42494 & -0.57469 & -0.13553\end{array}$
$\begin{array}{llll}\text { C } & 3.51228 & -1.43807 & -0.01866\end{array}$
$\begin{array}{llll}\text { C } & 3.34349 & -2.77994 & -0.34706\end{array}$
$\begin{array}{llll}\text { C } & 1.01880 & -2.38830 & -0.90962\end{array}$
$\begin{array}{llll}\text { C } & 2.10674 & -3.25242 & -0.78848\end{array}$
H $3.55793 \quad 3.84161 \quad 1.12410$
H $\quad 4.25702 \quad 1.48930 \quad 0.80839$
H $\quad 4.47509 \quad-1.07773 \quad 0.32306$
H $\quad 4.17826 \quad-3.46409 \quad-0.25862$
Н $\quad 0.06142 \quad-2.76249 \quad-1.25198$
H $\quad 1.99160 \quad-4.29966-1.03906$
C $\quad-1.15007 \quad-0.15184 \quad 0.05275$
$\begin{array}{llll}\text { C } & -3.54495 & -0.14417 & 0.20512\end{array}$
C $\quad-3.49612 \quad-0.53654 \quad 1.53016$
$\begin{array}{llll}\text { C } & -2.25694 & -0.72924 & 2.15540\end{array}$
$\begin{array}{llll}\text { C } & -1.10319 & -0.52021 & 1.39880\end{array}$
$\mathrm{H} \quad-4.50473 \quad 0.02439 \quad-0.26454$
H $\quad-4.41228 \quad-0.68977 \quad 2.08933$
$\begin{array}{llll}\mathrm{N} & -2.18032 & -1.17152 & 3.47465\end{array}$
$\mathrm{H} \quad-0.13766 \quad-0.64917 \quad 1.87653$
C $\quad-2.59556 \quad 0.44636 \quad-2.03658$
$\begin{array}{llll}\text { O } & -3.61143 & 1.14215 & -2.28714\end{array}$ 


$\begin{array}{llll}\mathrm{O} & -1.75826 & 0.03891 & -2.88686 \\ \mathrm{H} & 1.24064 & 4.53491 & 0.63556 \\ \mathrm{C} & 0.98431 & 1.25669 & -0.14742 \\ \mathrm{H} & -0.41905 & 2.88802 & -0.18063 \\ \mathrm{H} & -0.07529 & 0.24501 & -1.71851 \\ \mathrm{H} & -2.98174 & -0.95502 & 4.04830 \\ \mathrm{H} & -1.31469 & -0.96269 & 3.94930 \\ \mathrm{C} & -2.39446 & 0.04306 & -0.57339\end{array}$

Electronic Energy (0 K): -976.312672695

Enthalpy (298.150 K): -976.007424

Free Energy (298.150 K): -976.073404 


\section{3 $\operatorname{Fr}(\mathrm{C} \bullet)\left(\mathrm{NH}_{2}\right) \mathrm{CO}_{2}{ }^{-}$Carbon Radical}

B3LYP/def2TZVP opt=tight int=ultrafine
$\begin{array}{ll}-1 & 2\end{array}$
C $\quad 1.71715 \quad-3.10200 \quad-1.32103$
C $\quad 3.05684 \quad-2.71047 \quad-1.24698$
$\begin{array}{llll}\text { C } & 3.40214 & -1.43003 & -0.80703\end{array}$
C $\quad 0.69766 \quad-2.22975 \quad-0.95324$
$\begin{array}{llll}\text { C } & 2.39566 & -0.55195 & -0.43812\end{array}$
$\begin{array}{llll}\text { C } & 0.19868 & 0.15408 & -0.08655\end{array}$
$\begin{array}{llll}\text { C } & 1.07899 & 1.24993 & 0.22443\end{array}$
$\begin{array}{llll}\text { C } & 2.42918 & 0.83255 & 0.02979\end{array}$
$\begin{array}{llll}\text { C } & 3.47763 & 1.70016 & 0.28766\end{array}$
$\begin{array}{llll}\text { C } & 3.19394 & 2.99062 & 0.74378\end{array}$
$\begin{array}{llll}\text { C } & 0.81134 & 2.54174 & 0.69080\end{array}$
$\begin{array}{llll}\text { C } & 1.87358 & 3.40338 & 0.94403\end{array}$
H $\quad 3.83488 \quad-3.40489 \quad-1.53802$
H $\quad 4.44367 \quad-1.13470 \quad-0.76301$
$\begin{array}{llll}\mathrm{H} & 4.50593 & 1.39082 & 0.14347\end{array}$
$\begin{array}{llll}\mathrm{H} & 4.00618 & 3.67671 & 0.94821\end{array}$
$\begin{array}{llll}\mathrm{H} & -0.20753 & 2.86815 & 0.85618\end{array}$
$\begin{array}{llll}\mathrm{H} & 1.67656 & 4.40553 & 1.30368\end{array}$
$\begin{array}{llll}\text { C } & -1.26869 & 0.19837 & -0.09359\end{array}$
C $\quad-3.45368 \quad-0.63249 \quad 0.46166$
$\begin{array}{llll}\text { C } & -4.05542 & 0.32431 & -0.34023\end{array}$
$\begin{array}{llll}\text { C } & -3.26856 & 1.24739 & -1.03907\end{array}$
C $\quad-1.87974 \quad 1.16112 \quad-0.90708$
H $\quad-4.06990 \quad-1.34092 \quad 0.99977$
$\begin{array}{llll}\mathrm{H} & -5.13542 & 0.36329 & -0.42558\end{array}$
$\begin{array}{llll}\mathrm{N} & -3.85096 & 2.25421 & -1.80498\end{array}$
$\begin{array}{llll}\mathrm{H} & -1.25670 & 1.84230 & -1.47496\end{array}$
C $\quad-1.51116 \quad-1.70816 \quad 1.63890$
$\begin{array}{llll}\text { O } & -2.13389 & -2.79428 & 1.76384\end{array}$ 

O $\quad-0.49874 \quad-1.35110 \quad 2.29273$
Н $\quad 1.47081 \quad-4.09709 \quad-1.66990$
$\begin{array}{llll}\text { C } & 1.02867 & -0.94976 & -0.49977\end{array}$
H $\quad-0.33669-2.54320 \quad-1.01312$
H $\quad-4.77819 \quad 2.05366 \quad-2.14866$
$\mathrm{H} \quad-3.26201 \quad 2.64493 \quad-2.52505$
C $\quad-2.06986-0.71254 \quad 0.62653$

Electronic Energy (0 K): -975.684494682

Enthalpy (298.150 K): -975.392074

Free Energy (298.150 K): -975.458288 


\section{$5.4 \operatorname{Frr}(\mathrm{C} \bullet)\left(\mathrm{NH}_{2}\right) \mathrm{CO}_{2} \mathrm{H}$ Carbon Radical}

B3LYP/def2TZVP opt=tight int=ultrafine
$0 \quad 2$
$\begin{array}{llll}\text { C } & 1.690686 & -3.099761 & -1.382697\end{array}$
$\begin{array}{llll}\text { C } & 3.033147 & -2.724484 & -1.300462\end{array}$
$\begin{array}{llll}\text { C } & 3.396429 & -1.456483 & -0.835810\end{array}$
$\begin{array}{llll}\text { C } & 0.681807 & -2.223249 & -0.996643\end{array}$
$\begin{array}{llll}\text { C } & 2.402830 & -0.574961 & -0.447788\end{array}$
$\begin{array}{llll}\text { C } & 0.217504 & 0.151059 & -0.078621\end{array}$
$\begin{array}{llll}\text { C } & 1.110198 & 1.232655 & 0.253854\end{array}$
$\begin{array}{llll}\text { C } & 2.453345 & 0.801293 & 0.045913\end{array}$
$\begin{array}{llll}\text { C } & 3.511137 & 1.651798 & 0.313227\end{array}$
$\begin{array}{llll}\text { C } & 3.241370 & 2.938487 & 0.791157\end{array}$
$\begin{array}{llll}\text { C } & 0.855059 & 2.519070 & 0.741622\end{array}$
$\begin{array}{llll}\text { C } & 1.928236 & 3.364154 & 1.003386\end{array}$
$\begin{array}{llll}\mathrm{H} & 3.802784 & -3.421602 & -1.606030\end{array}$

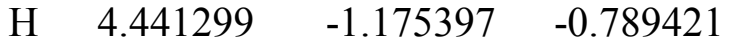
$\mathrm{H} \quad 4.535293 \quad 1.335290 \quad 0.158826$
$\begin{array}{llll}\mathrm{H} & 4.062098 & 3.611872 & 1.002525\end{array}$
$\mathrm{H} \quad-0.159384 \quad 2.853835 \quad 0.915686$
$\begin{array}{llll}\mathrm{H} & 1.744434 & 4.362724 & 1.378390\end{array}$
$\begin{array}{llll}\text { C } & -1.252736 & 0.219989 & -0.101996\end{array}$
$\begin{array}{llll}\text { C } & -3.486898 & -0.572163 & 0.383952\end{array}$
$\begin{array}{llll}\text { C } & -4.039450 & 0.387127 & -0.434595\end{array}$
$\begin{array}{llll}\text { C } & -3.209087 & 1.306343 & -1.099187\end{array}$
$\begin{array}{llll}\text { C } & -1.821917 & 1.195681 & -0.918559\end{array}$
H $\quad-4.132902 \quad-1.261774 \quad 0.909420$
$\begin{array}{llll}\mathrm{H} & -5.113595 & 0.442376 & -0.559884\end{array}$ 


$\begin{array}{llll}\mathrm{N} & -3.735952 & 2.303143 & -1.874414 \\ \mathrm{H} & -1.170066 & 1.866467 & -1.463561 \\ \mathrm{C} & -1.680024 & -1.683313 & 1.596642 \\ \mathrm{O} & -2.371779 & -2.620626 & 1.935953 \\ \mathrm{O} & -0.485899 & -1.526705 & 2.210758 \\ \mathrm{H} & 1.432374 & -4.083240 & -1.753607 \\ \mathrm{C} & 1.031961 & -0.957726 & -0.516796 \\ \mathrm{H} & -0.356266 & -2.521119 & -1.072124 \\ \mathrm{H} & -4.689467 & 2.215089 & -2.184981 \\ \mathrm{H} & -3.126240 & 2.787863 & -2.512127 \\ \mathrm{C} & -2.104073 & -0.676742 & 0.591905 \\ \mathrm{H} & -0.014426 & -0.748389 & 1.873070\end{array}$

Electronic Energy (0 K): -976.152468921

Enthalpy (298.150 K): -975.847144

Free Energy (298.150 K): -975.913552 


\section{$5.5 \quad \mathrm{Flr}(\mathrm{OMe}) \mathrm{CO}_{2} \mathrm{H}$}

B3LYP/def2TZVP opt=tight int=ultrafine

\begin{tabular}{|l|l|l|l|}
\hline 0 & 1 & & \\
\hline $\mathrm{C}$ & 1.70644 & -2.71387 & -2.22738 \\
\hline $\mathrm{C}$ & 2.90821 & -2.06117 & -2.50114 \\
\hline $\mathrm{C}$ & 3.28946 & -0.94035 & -1.76940 \\
\hline $\mathrm{C}$ & 0.86528 & -2.25627 & -1.21304 \\
\hline $\mathrm{C}$ & 2.44940 & -0.48013 & -0.75864 \\
\hline $\mathrm{C}$ & 0.52025 & -0.46338 & 0.67894 \\
\hline $\mathrm{C}$ & 1.45389 & 0.69714 & 0.99190 \\
\hline $\mathrm{C}$ & 2.58231 & 0.65649 & 0.15700 \\
\hline $\mathrm{C}$ & 3.59196 & 1.60688 & 0.28635 \\
\hline $\mathrm{C}$ & 3.46034 & 2.59897 & 1.25309 \\
\hline $\mathrm{C}$ & 1.32701 & 1.68804 & 1.95270 \\
\hline $\mathrm{C}$ & 2.33736 & 2.64120 & 2.07909 \\
\hline $\mathrm{H}$ & 3.54971 & -2.42955 & -3.29176 \\
\hline $\mathrm{H}$ & 4.22378 & -0.43814 & -1.98774 \\
\hline $\mathrm{H}$ & 4.46595 & 1.58018 & -0.35258 \\
\hline $\mathrm{H}$ & 4.23576 & 3.34636 & 1.36463 \\
\hline $\mathrm{H}$ & 0.45771 & 1.73561 & 2.59706 \\
\hline $\mathrm{H}$ & 2.24850 & 3.42082 & 2.82496 \\
\hline $\mathrm{C}$ & -0.92216 & -0.09031 & 0.35618 \\
\hline $\mathrm{C}$ & -2.02622 & -0.83477 & 0.81725 \\
\hline $\mathrm{C}$ & -3.30669 & -0.51964 & 0.35596 \\
\hline $\mathrm{C}$ & -3.53185 & 0.53891 & -0.50779 \\
\hline $\mathrm{C}$ & -2.44156 & 1.29171 & -0.95025 \\
\hline $\mathrm{C}$ & -1.15532 & 0.95886 & -0.52403 \\
\hline $\mathrm{H}$ & -4.14668 & -1.11010 & 0.69772 \\
\hline $\mathrm{H}$ & -2.53897 & 0.76406 & -0.82413 \\
\hline & & 2.34543 & -1.79563 \\
\hline
\end{tabular}




\begin{tabular}{|l|l|l|l|}
\hline $\mathrm{C}$ & -1.93592 & -1.98910 & 1.76091 \\
\hline $\mathrm{O}$ & -2.39813 & -3.08088 & 1.53397 \\
\hline $\mathrm{O}$ & -1.33398 & -1.77486 & 2.95484 \\
\hline $\mathrm{H}$ & 1.42372 & -3.58345 & -2.80699 \\
\hline $\mathrm{C}$ & 1.24211 & -1.14088 & -0.48294 \\
\hline $\mathrm{H}$ & -0.06703 & -2.76871 & -1.00897 \\
\hline $\mathrm{H}$ & 0.53339 & -1.15266 & 1.52686 \\
\hline $\mathrm{H}$ & -1.14732 & -0.83470 & 3.08709 \\
\hline $\mathrm{C}$ & -3.81634 & 2.72750 & -2.28707 \\
\hline $\mathrm{H}$ & -3.64217 & 3.57939 & -2.93861 \\
\hline $\mathrm{H}$ & -4.47847 & 3.02244 & -1.47030 \\
\hline $\mathrm{H}$ & -4.27514 & 1.91840 & -2.85920 \\
\hline
\end{tabular}

Electronic Energy (0 K): -1035.96077049

Enthalpy (298.150 K): -1035.625321

Free Energy (298.150 K): -1035.694310 


\section{$5.6 \mathrm{~F} \operatorname{lr}(\mathrm{OMe}) \mathrm{CO}_{2}^{-}$}

B3LYP/def2TZVP opt=tight int=ultrafine
$-1 \quad 1$
$\begin{array}{llll}\text { C } & 2.17499 & 2.61317 & -2.17760\end{array}$
$\begin{array}{llll}\text { C } & 3.32867 & 2.63332 & -1.39280\end{array}$
$\begin{array}{llll}\text { C } & 3.52850 & 1.67565 & -0.40287\end{array}$
$\begin{array}{llll}\text { C } & 1.20226 & 1.63247 & -1.98463\end{array}$
$\begin{array}{llll}\text { C } & 2.55585 & 0.69758 & -0.20691\end{array}$
$\begin{array}{llll}\text { C } & 0.51366 & -0.50097 & -0.62419\end{array}$
$\begin{array}{llll}\text { C } & 1.29249 & -1.11854 & 0.52523\end{array}$
$\begin{array}{llll}\text { C } & 2.49170 & -0.41807 & 0.74161\end{array}$
C $\quad 3.38302 \quad-0.82991 \quad 1.72993$
$\begin{array}{llll}\text { C } & 3.06325 & -1.94278 & 2.50228\end{array}$
C $\quad 0.97959 \quad-2.22666 \quad 1.29760$
C $\quad 1.87085 \quad-2.63556 \quad 2.28950$
$\mathrm{H} \quad 4.07428 \quad 3.40160 \quad-1.55554$
$\begin{array}{llll}\mathrm{H} & 4.42661 & 1.69687 & 0.20247\end{array}$
H $\quad 4.31043 \quad-0.29665 \quad 1.90041$
H $3.74477 \quad-2.27373 \quad 3.27602$
$\mathrm{H} \quad 0.05502 \quad-2.76904 \quad 1.13913$
H $\quad 1.63610 \quad-3.49873 \quad 2.89983$
$\begin{array}{llll}\text { C } & -0.93705 & -0.16393 & -0.30276\end{array}$
$\begin{array}{llll}\text { C } & -2.01858 & -0.83706 & -0.90280\end{array}$
$\begin{array}{llll}\text { C } & -3.30882 & -0.49273 & -0.49424\end{array}$
$\begin{array}{llll}\text { C } & -3.56228 & 0.49789 & 0.44587\end{array}$
$\begin{array}{llll}\text { C } & -2.48334 & 1.15713 & 1.03462\end{array}$
$\begin{array}{llll}\text { C } & -1.18728 & 0.81033 & 0.66107\end{array}$
H $\quad-4.14144 \quad-1.02201 \quad-0.93828$
$\mathrm{H} \quad-4.58186 \quad 0.73819 \quad 0.70979$
$\begin{array}{llll}\text { O } & -2.59569 & 2.13799 & 1.97664\end{array}$
$\begin{array}{llll}\mathrm{H} & -0.36318 & 1.32232 & 1.14358\end{array}$
$\begin{array}{llll}\text { C } & -1.88417 & -1.91976 & -1.97766\end{array}$ 

O $\quad-2.69862 \quad-2.87273 \quad-1.91072$
$\begin{array}{llll}\mathrm{O} & -0.99573 & -1.76457 & -2.85711\end{array}$
H $\quad 2.03437 \quad 3.36596 \quad-2.94325$
C $\quad 1.39492 \quad 0.67670 \quad-0.99867$
H $\quad 0.30888 \quad 1.62305 \quad-2.59737$
H $0.49163 \quad-1.19613-1.46766$
C $\quad \begin{array}{llll}-3.89873 & 2.52378 & 2.40201\end{array}$
H $\quad-3.75221 \quad 3.30362 \quad 3.14527$
H $\quad-4.43314 \quad 1.68572 \quad 2.85647$
H $\quad-4.48714 \quad 2.92117 \quad 1.57116$

Electronic Energy (0 K): -1035.49950886 Hartrees

Enthalpy (298.150 K): -1035.177315 Hartrees

Free Energy (298.150 K): -1035.246408 Hartrees 


\section{7 $\mathrm{F} \operatorname{lr}(\mathrm{C} \bullet)(\mathrm{OMe}) \mathrm{CO}_{2}{ }^{-}$Carbon Radical}

B3LYP/def2TZVP opt=tight int=ultrafine
$-12$
C $\quad 2.39745 \quad-2.76689 \quad-1.53189$
$\begin{array}{llll}\text { C } & 3.65220 & -2.15167 & -1.52537\end{array}$
$\begin{array}{llll}\text { C } & 3.80536 & -0.84934 & -1.04268\end{array}$
$\begin{array}{llll}\text { C } & 1.27378 & -2.10123 & -1.05249\end{array}$
$\begin{array}{llll}\text { C } & 2.69389 & -0.17595 & -0.56252\end{array}$
$\begin{array}{llll}\text { C } & 0.44115 & 0.12411 & -0.03223\end{array}$
$\begin{array}{llll}\text { C } & 1.14243 & 1.34321 & 0.27724\end{array}$
$\begin{array}{llll}\text { C } & 2.52552 & 1.17388 & -0.02737\end{array}$
$\begin{array}{llll}\text { C } & 3.42782 & 2.19842 & 0.20527\end{array}$
$\begin{array}{llll}\text { C } & 2.96394 & 3.40118 & 0.74568\end{array}$
$\begin{array}{llll}\text { C } & 0.69498 & 2.54921 & 0.82785\end{array}$
$\begin{array}{llll}\text { C } & 1.61152 & 3.57085 & 1.05448\end{array}$
H $\quad 4.51366 \quad-2.68765 \quad-1.90333$
H $\quad 4.78122 \quad-0.37874 \quad-1.05240$
H $44.48003 \quad 2.07695 \quad-0.02246$
H $\quad 3.66088 \quad 4.20868 \quad 0.93117$
$\begin{array}{llll}\mathrm{H} & -0.34886 & 2.68802 & 1.07878\end{array}$
$\mathrm{H} \quad 1.27444 \quad 4.50837 \quad 1.47853$
$\begin{array}{llll}\text { C } & -1.00675 & -0.08907 & 0.07009\end{array}$
C $\quad-1.57821 \quad-1.17497 \quad 0.77222$
C $\quad-2.96030 \quad-1.32791 \quad 0.73038$
C $\quad-3.79651 \quad-0.43804 \quad 0.06186$
$\begin{array}{llll}\text { C } & -3.23038 & 0.64245 & -0.61100\end{array}$
$\begin{array}{llll}\text { C } & -1.84475 & 0.80187 & -0.60634\end{array}$

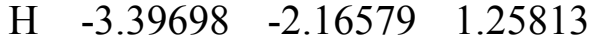
H $\quad-4.86524 \quad-0.59419 \quad 0.07722$
$\begin{array}{llll}\mathrm{O} & -3.93605 & 1.58011 & -1.30510\end{array}$

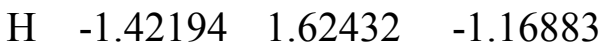
C $\quad-0.76656 \quad-2.12276 \quad 1.65366$ 

O $\quad-1.12497 \quad-3.32734 \quad 1.66533$
O $\quad 0.16546 \quad-1.61098 \quad 2.32160$
Н $\quad 2.29943 \quad-3.77455 \quad-1.91599$
C $\quad 1.41415 \quad-0.80275 \quad-0.55432$
H $\quad 0.30718 \quad-2.58799 \quad-1.06136$
C $\quad-5.35468 \quad 1.46208 \quad-1.35502$
$\mathrm{H} \quad-5.70345 \quad 2.30116 \quad-1.95180$
$\mathrm{H} \quad-5.79345 \quad 1.52038 \quad-0.35586$
$\mathrm{H} \quad-5.65883 \quad 0.52669 \quad-1.83133$

Electronic Energy (0 K): -1034.87126747 Hartrees

Enthalpy (298.150 K): -1034.561886 Hartrees

Free Energy (298.150 K): -1034.630834 Hartrees 


\section{$5.8 \mathrm{~F} \operatorname{lr}(\mathrm{C} \bullet)(\mathrm{OMe}) \mathrm{CO}_{2} \mathrm{H}$ Carbon Radical}

B3LYP/def2TZVP opt=tight int=ultrafine
02
$\begin{array}{llll}\text { C } & 2.342524 & -2.754505 & -1.634422\end{array}$
$\begin{array}{llll}\text { C } & 3.604228 & -2.156662 & -1.625661\end{array}$
$\begin{array}{llll}\text { C } & 3.784905 & -0.870227 & -1.107868\end{array}$
$\begin{array}{llll}\text { C } & 1.235350 & -2.087416 & -1.120157\end{array}$
$\begin{array}{llll}\text { C } & 2.692109 & -0.195937 & -0.592305\end{array}$
C $\quad 0.454590 \quad 0.120892 \quad-0.019569$
$\begin{array}{llll}\text { C } & 1.175406 & 1.323211 & 0.315052\end{array}$
$\begin{array}{llll}\text { C } & 2.550122 & 1.141637 & -0.016989\end{array}$
$\begin{array}{llll}\text { C } & 3.468197 & 2.147039 & 0.227414\end{array}$
$\begin{array}{llll}\text { C } & 3.026250 & 3.341595 & 0.805773\end{array}$
$\begin{array}{llll}\text { C } & 0.748809 & 2.519150 & 0.903000\end{array}$
$\begin{array}{llll}\text { C } & 1.682453 & 3.522449 & 1.140042\end{array}$
H $\quad 4.452633 \quad-2.692859 \quad-2.031077$
$\mathrm{H} \quad 4.767237 \quad-0.414405 \quad-1.119989$
$\mathrm{H} \quad 4.514725 \quad 2.019986 \quad-0.020445$
$\begin{array}{llll}\mathrm{H} & 3.736670 & 4.134780 & 1.000277\end{array}$
H $\quad-0.289038 \quad 2.664513 \quad 1.173459$
H $\quad 1.364858 \quad 4.453396 \quad 1.591674$
$\begin{array}{llll}\text { C } & -1.000259 & -0.068086 & 0.077923\end{array}$
$\begin{array}{llll}\text { C } & -1.619687 & -1.149748 & 0.755053\end{array}$
$\begin{array}{llll}\text { C } & -3.007075 & -1.282859 & 0.679615\end{array}$
$\begin{array}{llll}\text { C } & -3.803264 & -0.378220 & -0.002261\end{array}$
$\begin{array}{llll}\text { C } & -3.198484 & 0.706417 & -0.640712\end{array}$
$\begin{array}{llll}\text { C } & -1.808828 & 0.844881 & -0.595617\end{array}$
H $\quad-3.469855 \quad-2.112220 \quad 1.196078$ 


$\begin{array}{cccc}\mathrm{H} & -4.873334 & -0.518341 & -0.021216 \\ \mathrm{O} & -3.861861 & 1.658025 & -1.330980 \\ \mathrm{H} & -1.359677 & 1.666521 & -1.136634 \\ \mathrm{C} & -0.925619 & -2.138664 & 1.627748 \\ \mathrm{O} & -1.377696 & -3.233340 & 1.880163 \\ \mathrm{O} & 0.235346 & -1.777332 & 2.212878 \\ \mathrm{H} & 2.224210 & -3.747331 & -2.048860 \\ \mathrm{C} & 1.404931 & -0.806923 & -0.585483 \\ \mathrm{H} & 0.260286 & -2.557306 & -1.141785 \\ \mathrm{C} & -5.285243 & 1.572298 & -1.434787 \\ \mathrm{H} & -5.589208 & 2.431396 & -2.026082 \\ \mathrm{H} & -5.753603 & 1.621860 & -0.449965 \\ \mathrm{H} & -5.586327 & 0.653806 & -1.942228 \\ \mathrm{H} & 0.505618 & -0.884570 & 1.945567\end{array}$

Electronic Energy (0 K): -1035.33655790

Enthalpy (298.150 K): -1035.014119

Free Energy (298.150 K): -1035.083561 


\section{$5.9 \quad \operatorname{Frr}(\mathrm{H}) \mathrm{CO}_{2} \mathrm{H}$}

B3LYP/def2TZVP opt=tight int=ultrafine
$\begin{array}{ll}0 & 1\end{array}$
C $\quad 1.08983 \quad 3.56596 \quad 0.14086$
C $\quad 2.44985 \quad 3.33796 \quad 0.35000$
$\begin{array}{llll}\text { C } & 2.97059 & 2.04853 & 0.29196\end{array}$
$\begin{array}{llll}\text { C } & 0.22642 & 2.50510 & -0.13253\end{array}$
$\begin{array}{llll}\text { C } & 2.10966 & 0.98781 & 0.02199\end{array}$
$\begin{array}{llll}\text { C } & 0.02165 & -0.08979 & -0.49456\end{array}$
$\begin{array}{llll}\text { C } & 1.15237 & -1.10185 & -0.37584\end{array}$
$\begin{array}{llll}\text { C } & 2.36467 & -0.45085 & -0.09529\end{array}$
$\begin{array}{llll}\text { C } & 3.54554 & -1.17885 & 0.02628\end{array}$
$\begin{array}{llll}\text { C } & 3.50141 & -2.56091 & -0.12990\end{array}$
$\begin{array}{llll}\text { C } & 1.11309 & -2.47881 & -0.52888\end{array}$
$\begin{array}{llll}\text { C } & 2.29601 & -3.20699 & -0.40340\end{array}$
$\begin{array}{llll}\text { H } & 3.10637 & 4.17271 & 0.56089\end{array}$
$\mathrm{H} \quad 4.02766 \quad 1.87931 \quad 0.45561$
H $\quad 4.48468 \quad-0.68382 \quad 0.24011$
H $\quad 4.41080 \quad-3.14105 \quad-0.03625$
$\mathrm{H} \quad 0.18251 \quad-2.99291 \quad-0.73667$
H $\quad 2.27798 \quad-4.28321 \quad-0.51934$
$\begin{array}{llll}\text { C } & -1.18560 & -0.34186 & 0.39793\end{array}$
$\begin{array}{llll}\text { C } & -2.50544 & -0.19174 & -0.05314\end{array}$
C $\quad-3.57924 \quad-0.32754 \quad 0.83382$
$\begin{array}{llll}\text { C } & -3.35790 & -0.64663 & 2.16310\end{array}$
$\begin{array}{llll}\text { C } & -2.05274 & -0.80818 & 2.61967\end{array}$
$\begin{array}{llll}\text { C } & -0.98716 & -0.64751 & 1.74763\end{array}$
H $\quad-4.58833 \quad-0.19035 \quad 0.46739$
H $\quad-4.19499 \quad-0.765392 .83832$
H $\quad-1.86569-1.05172 \quad 3.65765$
$\begin{array}{llll}\mathrm{H} & 0.02434 & -0.75570 & 2.11807\end{array}$
$\begin{array}{llll}\text { C } & -2.85184 & 0.15820 & -1.46989\end{array}$ 

$\begin{array}{llll}\mathrm{O} & -3.40725 & 1.17847 & -1.79133\end{array}$
O $\quad-2.54420 \quad-0.75130 \quad-2.42019$
H $\quad 0.70076 \quad 4.57500 \quad 0.19087$
$\begin{array}{llll}\text { C } & 0.74197 & 1.22064 & -0.19115\end{array}$
H $\quad-0.82882 \quad 2.69063 \quad-0.29259$
$\mathrm{H} \quad-0.30290 \quad-0.06077 \quad-1.53855$
H $\quad-2.20156 \quad-1.56620 \quad-2.02535$

Electronic Energy (0 K): -921.387822825

Enthalpy (298.150 K): -921.087223

Free Energy (298.150 K): -921.150406 


\section{$5.10 \mathrm{~F} \operatorname{lr}(\mathrm{H}) \mathrm{CO}_{2}^{-}$}

B3LYP/def2TZVP opt=tight int=ultrafine
$-1 \quad 1$
C $\quad 1.33057 \quad 3.54235 \quad 0.03328$
C $2.67340 \quad 3.22689 \quad 0.24340$
$\begin{array}{llll}\text { C } & 3.10118 & 1.90249 & 0.22553\end{array}$
$\begin{array}{llll}\text { C } & 0.39334 & 2.53610 & -0.20028\end{array}$
$\begin{array}{llll}\text { C } & 2.16542 & 0.89639 & -0.00425\end{array}$
C $\quad 0.00218 \quad-0.04444 \quad-0.47798$
C $\quad 1.05725 \quad-1.12730-0.33255$
C $2.31695 \quad-0.55996-0.07622$
$\begin{array}{llll}\text { C } & 3.44231 & -1.36948 & 0.06187\end{array}$
C $3.29623 \quad-2.74869-0.05468$
C $\quad 0.91790 \quad-2.50174 \quad-0.44896$
$\begin{array}{llll}\text { C } & 2.04465 & -3.31149 & -0.30742\end{array}$
H $1.01385 \quad 4.57771 \quad 0.05142$
H $3.38850 \quad 4.02002 \quad 0.42292$
H $\quad 4.14531 \quad 1.66493 \quad 0.38927$
H $\quad 4.41696 \quad-0.93930 \quad 0.25779$
H $4.16111-3.39146 \quad 0.05245$
H $\quad-0.05089-2.94510 \quad-0.64495$
H $1.94802 \quad-4.38652-0.39454$
C $\quad-1.22662 \quad-0.20215 \quad 0.40758$
C $\quad-2.53049 \quad-0.13961 \quad-0.10815$
$\begin{array}{llll}\text { C } & -3.61230 & -0.24556 & 0.77478\end{array}$
$\begin{array}{llll}\text { C } & -3.42445 & -0.43943 & 2.13517\end{array}$
C $\quad-2.13025 \quad-0.49596 \quad 2.64655$
C $\quad-1.05020 \quad-0.36743 \quad 1.78578$
H $\quad-4.61498 \quad-0.17534 \quad 0.37224$
$\mathrm{H} \quad-4.27858 \quad-0.53842 \quad 2.79397$
H $\quad-1.96470 \quad-0.63507 \quad 3.70779$
$\mathrm{H} \quad-0.04423 \quad-0.39781 \quad 2.18839$ 


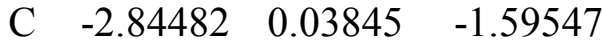
$\begin{array}{llll}\text { O } & -3.67092 & 0.93762 & -1.88263\end{array}$
$\begin{array}{llll}\mathrm{O} & -2.27190 & -0.74079 & -2.39930\end{array}$
$\begin{array}{llll}\text { C } & 0.81377 & 1.21523 & -0.21891\end{array}$
$\mathrm{H} \quad-0.64800 \quad 2.78817 \quad-0.36202$
H $\quad-0.34602 \quad-0.04444 \quad-1.51387$

Electronic Energy (0 K): -920.928195724

Enthalpy (298.150 K): -920.640873

Free Energy (298.150 K): -920.703686 


\section{$5.11 \operatorname{Fr}(\mathrm{C} \bullet)(\mathrm{H}) \mathrm{CO}_{2}{ }^{-}$Carbon Radical}

B3LYP/def2TZVP opt=tight int=ultrafine
$\begin{array}{ll}-1 & 2\end{array}$
C $\quad-0.92392 \quad 3.38063 \quad-0.90240$
$\begin{array}{llll}\text { C } & -2.30668 & 3.26622 & -0.73701\end{array}$
$\begin{array}{llll}\text { C } & -2.88759 & 2.03557 & -0.41945\end{array}$
$\begin{array}{llll}\text { C } & -0.09263 & 2.27565 & -0.74873\end{array}$
$\begin{array}{llll}\text { C } & -2.07077 & 0.92780 & -0.26299\end{array}$
$\begin{array}{llll}\text { C } & -0.06073 & -0.25901 & -0.23430\end{array}$
$\begin{array}{llll}\text { C } & -1.13392 & -1.18249 & 0.03407\end{array}$
$\begin{array}{llll}\text { C } & -2.37027 & -0.47168 & 0.03399\end{array}$
C $\quad-3.56051 \quad-1.12941 \quad 0.29630$
C $\quad-3.53281 \quad-2.50096 \quad 0.56410$
C $\quad-1.12115 \quad-2.55293 \quad 0.31603$
$\begin{array}{llll}\text { C } & -2.32392 & -3.20192 & 0.57564\end{array}$
$\mathrm{H} \quad-0.49464 \quad 4.34214 \quad-1.15481$
$\mathrm{H} \quad-2.93532 \quad 4.13881 \quad-0.86208$

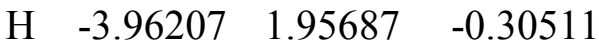
$\mathrm{H} \quad-4.50348 \quad-0.59599 \quad 0.29981$
H $\quad-4.45755 \quad-3.02485 \quad 0.77038$
H $\quad-0.18979 \quad-3.10413 \quad 0.33808$
H $\quad-2.32396 \quad-4.26258 \quad 0.79324$
$\begin{array}{llll}\text { C } & 1.35559 & -0.60587 & -0.37949\end{array}$
$\begin{array}{lllll}\text { C } & 2.38376 & 0.04701 & 0.33388\end{array}$
$\begin{array}{llll}\text { C } & 3.71033 & -0.30139 & 0.07622\end{array}$
$\begin{array}{llll}\text { C } & 4.03986 & -1.29851 & -0.83381\end{array}$
$\begin{array}{llll}\text { C } & 3.02872 & -1.95740 & -1.52541\end{array}$
C $\quad 1.70482 \quad-1.60773 \quad-1.30039$
$\begin{array}{llll}\mathrm{H} & 4.49171 & 0.21483 & 0.61925\end{array}$
H $\quad 5.07747 \quad-1.56049 \quad-1.00051$
H $3.26809 \quad-2.73202 \quad-2.24316$
Н $\quad 0.92088 \quad-2.09739 \quad-1.86431$ 

C $\quad 2.11008 \quad 1.05419 \quad 1.45204$
$\begin{array}{llll}\text { O } & 2.79447 & 2.10642 & 1.43920\end{array}$
$\begin{array}{llll}\text { O } & 1.25443 & 0.71832 & 2.30578\end{array}$
$\begin{array}{llll}\text { C } & -0.65819 & 1.04054 & -0.41740\end{array}$
$\begin{array}{llll}\mathrm{H} & 0.97702 & 2.37707 & -0.87606\end{array}$

Electronic Energy (0 K): -920.300091263

Enthalpy (298.150 K): -920.025672

Free Energy (298.150 K): -920.088467 


\section{$5.12 \operatorname{Fr}(\mathrm{C} \bullet)(\mathrm{H}) \mathrm{CO}_{2} \mathrm{H}$ Carbon Radical}

B3LYP/def2TZVP opt=tight int=ultrafine
02
$\begin{array}{llll}\text { C } & -0.880014 & 3.379045 & -0.945350\end{array}$
$\begin{array}{llll}\text { C } & -2.262745 & 3.288147 & -0.775368\end{array}$
$\begin{array}{llll}\text { C } & -2.865437 & 2.070479 & -0.444999\end{array}$
$\begin{array}{llll}\text { C } & -0.067477 & 2.261798 & -0.780634\end{array}$
$\begin{array}{llll}\text { C } & -0.654894 & 1.041968 & -0.431826\end{array}$
$\begin{array}{llll}\text { C } & -2.068341 & 0.951817 & -0.276691\end{array}$
$\begin{array}{llll}\text { C } & -0.081696 & -0.267576 & -0.229235\end{array}$
$\begin{array}{llll}\text { C } & -1.169051 & -1.173710 & 0.045619\end{array}$
$\begin{array}{llll}\text { C } & -2.391710 & -0.440621 & 0.033332\end{array}$
$\begin{array}{llll}\text { C } & -3.592669 & -1.075907 & 0.294671\end{array}$
$\begin{array}{llll}\text { C } & -3.587390 & -2.446566 & 0.572610\end{array}$
$\begin{array}{llll}\text { C } & -1.177209 & -2.542003 & 0.338526\end{array}$
$\begin{array}{llll}\text { C } & -2.392149 & -3.168364 & 0.595879\end{array}$

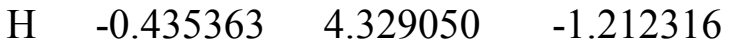
$\begin{array}{llll}\mathrm{H} & -2.877088 & 4.169286 & -0.908938\end{array}$
$\begin{array}{llll}\mathrm{H} & -3.940831 & 2.011838 & -0.331078\end{array}$
H $1.001594 \quad 2.344593 \quad-0.929246$
$\mathrm{H} \quad-4.527056 \quad-0.528414 \quad 0.288789$
H $\quad-4.521812 \quad-2.953127 \quad 0.777457$

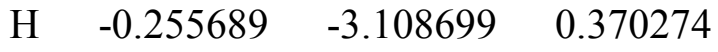
$\mathrm{H} \quad-2.411463 \quad-4.227032 \quad 0.820343$
$\begin{array}{llll}\text { C } & 1.329453 & -0.636889 & -0.378199\end{array}$
$\begin{array}{llll}\text { C } & 2.389128 & 0.011217 & 0.296851\end{array}$
$\begin{array}{llll}\text { C } & 3.712473 & -0.328386 & 0.006207\end{array}$
$\begin{array}{llll}\text { C } & 4.010810 & -1.325157 & -0.909493\end{array}$ 


$\begin{array}{llll}\mathrm{C} & 2.975185 & -1.993258 & -1.554267 \\ \mathrm{C} & 1.657637 & -1.650050 & -1.292629 \\ \mathrm{H} & 4.505085 & 0.186641 & 0.531195 \\ \mathrm{H} & 5.041580 & -1.583359 & -1.112537 \\ \mathrm{H} & 3.192463 & -2.773958 & -2.271729 \\ \mathrm{H} & 0.860041 & -2.143884 & -1.830964 \\ \mathrm{C} & 2.209024 & 1.019747 & 1.388786 \\ \mathrm{O} & 2.981423 & 1.928121 & 1.583653 \\ \mathrm{O} & 1.166610 & 0.862884 & 2.228606 \\ \mathrm{H} & 0.626701 & 0.094629 & 1.987943\end{array}$

Electronic Energy (0 K): -920.762793152

Enthalpy (298.150 K): -920.475294

Free Energy (298.150 K): -920.538418 


\section{$5.13 \operatorname{Flr}\left(\mathrm{CF}_{3}\right) \mathrm{CO}_{2} \mathrm{H}$}

B3LYP/def2TZVP opt=tight int=ultrafine
$\begin{array}{ll}0 & 1\end{array}$
$\begin{array}{llll}\text { C } & 2.49721 & 1.12824 & 3.10737\end{array}$
$\begin{array}{llll}\text { C } & 3.45294 & 0.12043 & 2.97826\end{array}$
$\begin{array}{llll}\text { C } & 3.56592 & -0.60402 & 1.79523\end{array}$
C $\quad 1.63658 \quad 1.42995 \quad 2.05202$
$\begin{array}{llll}\text { C } & 2.70556 & -0.30714 & 0.74129\end{array}$
$\begin{array}{llll}\text { C } & 0.95187 & 0.85955 & -0.41782\end{array}$
$\begin{array}{llll}\text { C } & 1.55729 & -0.23351 & -1.28657\end{array}$
$\begin{array}{llll}\text { C } & 2.59030 & -0.89017 & -0.59885\end{array}$
$\begin{array}{llll}\text { C } & 3.30934 & -1.91083 & -1.21590\end{array}$
$\begin{array}{llll}\text { C } & 2.98267 & -2.26789 & -2.52077\end{array}$
$\begin{array}{llll}\text { C } & 1.23592 & -0.59052 & -2.58632\end{array}$
$\begin{array}{llll}\text { C } & 1.95506 & -1.61485 & -3.20161\end{array}$
H $\quad 4.11343 \quad-0.10025 \quad 3.80735$
Н $4.31119 \quad-1.38429 \quad 1.70222$
$\begin{array}{llll}\mathrm{H} & 4.10902 & -2.42195 & -0.69433\end{array}$
H $3.53125 \quad-3.06096 \quad-3.01314$
$\begin{array}{llll}\mathrm{H} & 0.43867 & -0.08807 & -3.12079\end{array}$
H $1.71427 \quad-1.90529 \quad-4.21635$
$\begin{array}{llll}\text { C } & -0.55386 & 0.75605 & -0.23152\end{array}$
C $\quad-1.43548 \quad 1.82757 \quad-0.44191$
$\begin{array}{llll}\text { C } & -2.81391 & 1.65117 & -0.27022\end{array}$
$\begin{array}{llll}\text { C } & -3.33222 & 0.43183 & 0.12552\end{array}$
$\begin{array}{llll}\text { C } & -2.46158 & -0.63350 & 0.33562\end{array}$
$\begin{array}{llll}\text { C } & -1.09685 & -0.47166 & 0.14996\end{array}$

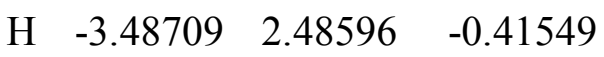
H $\quad-4.39637 \quad 0.31585 \quad 0.27361$
$\begin{array}{llll}\text { C } & -3.00968 & -1.98306 & 0.71529\end{array}$
$\mathrm{H} \quad-0.43471 \quad-1.31250 \quad 0.30547$
$\begin{array}{llll}\text { C } & -0.94197 & 3.19773 & -0.79477\end{array}$ 

$\begin{array}{llll}\mathrm{O} & -0.02335 & 3.75177 & -0.24338\end{array}$
$\begin{array}{llll}\text { O } & -1.60874 & 3.84267 & -1.77291\end{array}$
H $2.42365 \quad 1.68199 \quad 4.03477$
C $\quad 1.74615 \quad 0.70974 \quad 0.87356$
$\mathrm{H} \quad 0.89916 \quad 2.21620 \quad 2.15396$
H $1.18658 \quad 1.82982 \quad-0.85721$
H $\quad-2.26109 \quad 3.26839 \quad-2.19959$
F $\quad-4.13048 \quad-1.88820 \quad 1.45946$
F $\quad-2.12732 \quad-2.71853 \quad 1.42068$
F $\quad-3.33540 \quad-2.71673 \quad-0.37761$

Electronic Energy (0 K): -1258.58270457

Enthalpy (298.150 K): -1258.274331

Free Energy (298.150 K): -1258.347359 


\section{$5.14 \operatorname{Flr}\left(\mathrm{CF}_{3}\right) \mathrm{CO}_{2}^{-}$}

B3LYP/def2TZVP opt=tight int=ultrafine
$-1 \quad 1$
C $\quad 2.29520 \quad 1.13236 \quad 3.22109$
$\begin{array}{llll}\text { C } & 3.26586 & 0.13242 & 3.15454\end{array}$
$\begin{array}{llll}\text { C } & 3.45326 & -0.59702 & 1.98406\end{array}$
$\begin{array}{llll}\text { C } & 1.49602 & 1.42024 & 2.11479\end{array}$
C $2.65347 \quad-0.31308 \quad 0.87960$
C $\quad 0.961890 .83498 \quad-0.38786$
C $1.62279 \quad-0.25858 \quad-1.21026$
C $2.61985 \quad-0.90523-0.46113$
$\begin{array}{llll}\text { C } & 3.37959 & -1.92558 & -1.02863\end{array}$
C $3.13039 \quad-2.29435 \quad-2.34737$
$\begin{array}{llll}\text { C } & 1.37914 & -0.62877 & -2.52365\end{array}$
C $2.13843 \quad-1.65267 \quad-3.08965$
H $3.87835 \quad-0.07822 \quad 4.02231$
H $4.20895 \quad-1.37175 \quad 1.93950$
H $\quad 4.15155 \quad-2.42785 \quad-0.45852$
H $3.71102 \quad-3.08728 \quad-2.80201$
H $\quad 0.61070 \quad-0.13426 \quad-3.10535$
H $1.95711 \quad-1.95228-4.11425$
C $\quad-0.55558 \quad 0.75656 \quad-0.30070$
C $\quad-1.37571 \quad 1.85840 \quad-0.58366$
$\begin{array}{llll}\text { C } & -2.76185 & 1.72805 & -0.44070\end{array}$
C $\quad-3.34313 \quad 0.53296 \quad-0.05537$
$\begin{array}{llll}\text { C } & -2.52377 & -0.55810 & 0.23197\end{array}$
C $\quad-1.14580 \quad-0.438390 .11561$
$\mathrm{H} \quad-3.38833 \quad 2.58826 \quad-0.63752$
$\begin{array}{llll}\mathrm{H} & -4.41809 & 0.45172 & 0.03340\end{array}$
C $\quad-3.13475-1.87150 \quad 0.61651$
$\mathrm{H} \quad-0.51557 \quad-1.28573 \quad 0.35278$
C $\quad-0.83115 \quad 3.21223 \quad-1.04359$ 


$\begin{array}{llll}\mathrm{O} & -1.17401 & 4.20248 & -0.35715 \\ \mathrm{O} & -0.11253 & 3.21052 & -2.07284 \\ \mathrm{H} & 2.16178 & 1.69000 & 4.13960 \\ \mathrm{C} & 1.67845 & 0.69614 & 0.94711 \\ \mathrm{H} & 0.74417 & 2.19820 & 2.17340 \\ \mathrm{H} & 1.21151 & 1.79975 & -0.83578 \\ \mathrm{~F} & -4.28217 & -1.72470 & 1.31691 \\ \mathrm{~F} & -2.31189 & -2.63191 & 1.37138 \\ \mathrm{~F} & -3.45443 & -2.62792 & -0.46873\end{array}$

Electronic Energy (0 K): -1258.12498360

Enthalpy (298.150 K): -1257.829759

Free Energy (298.150 K): -1257.903209 


\section{$5.15 \operatorname{Flr}\left(\mathrm{C}^{\bullet}\right)\left(\mathrm{CF}_{3}\right) \mathrm{CO}_{2}{ }^{-}$Carbon Radical}

B3LYP/def2TZVP opt=tight int=ultrafine
$\begin{array}{ll}-1 & 2\end{array}$
$\begin{array}{llll}\text { C } & 3.17956 & -2.31255 & -1.73743\end{array}$
$\begin{array}{llll}\text { C } & 4.28967 & -1.46470 & -1.75466\end{array}$
$\begin{array}{llll}\text { C } & 4.21920 & -0.18483 & -1.19747\end{array}$
$\begin{array}{llll}\text { C } & 1.98021 & -1.90704 & -1.16035\end{array}$
$\begin{array}{llll}\text { C } & 3.03173 & 0.23064 & -0.61893\end{array}$
$\begin{array}{llll}\text { C } & 0.80054 & 0.05871 & 0.03820\end{array}$
$\begin{array}{llll}\text { C } & 1.27261 & 1.37349 & 0.39109\end{array}$
$\begin{array}{llll}\text { C } & 2.64074 & 1.49226 & 0.00762\end{array}$
$\begin{array}{llll}\text { C } & 3.34351 & 2.65805 & 0.26059\end{array}$
C $\quad 2.69252 \quad 3.71680 \quad 0.90053$
$\begin{array}{llll}\text { C } & 0.63816 & 2.43693 & 1.04220\end{array}$
$\begin{array}{llll}\text { C } & 1.35506 & 3.60354 & 1.28819\end{array}$
H $\quad 5.21290 \quad-1.80017 \quad-2.20988$
H $\quad 5.08323 \quad 0.46795 \quad-1.22743$
H $\quad 4.38352 \quad 2.75571 \quad-0.02638$
H $\quad 3.23266 \quad 4.63298 \quad 1.10282$
H $\quad-0.39431 \quad 2.35738 \quad 1.35766$
$\mathrm{H} \quad 0.87230 \quad 4.43274 \quad 1.78967$
$\begin{array}{llll}\text { C } & -0.56915 & -0.43398 & 0.21110\end{array}$
C $\quad-0.87493 \quad-1.64820 \quad 0.86082$
C $\quad-2.20442 \quad-2.06772 \quad 0.92125$
C $\quad-3.23599 \quad-1.30513 \quad 0.39666$
$\begin{array}{llll}\text { C } & -2.93664 & -0.09818 & -0.23062\end{array}$
$\begin{array}{llll}\text { C } & -1.61808 & 0.32692 & -0.32383\end{array}$
$\mathrm{H} \quad-2.42721 \quad-3.00980 \quad 1.40446$
H $\quad-4.25940 \quad-1.64726 \quad 0.47076$
$\begin{array}{llll}\text { C } & -4.04204 & 0.76112 & -0.76767\end{array}$

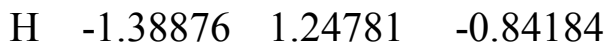
$\begin{array}{llll}\text { C } & 0.17378 & -2.49437 & 1.58557\end{array}$ 


$\begin{array}{llll}\text { O } & 0.16861 & -3.72118 & 1.32896 \\ \text { O } & 0.90711 & -1.88464 & 2.39807 \\ \text { H } & 3.25368 & -3.29770 & -2.18046 \\ \text { C } & 1.89931 & -0.63458 & -0.58631 \\ \text { H } & 1.12878 & -2.57437 & -1.15000 \\ \text { F } & -5.08541 & 0.03494 & -1.22724 \\ \text { F } & -3.64148 & 1.55585 & -1.78345 \\ \text { F } & -4.55258 & 1.59122 & 0.18126\end{array}$

Electronic Energy (0 K): -1257.49615492

Enthalpy (298.150 K): -1257.213827

Free Energy (298.150 K): -1257.286674 


\section{$5.16 \operatorname{Flr}\left(\mathrm{C}^{\bullet}\right)\left(\mathrm{CF}_{3}\right) \mathrm{CO}_{2} \mathrm{H}$ Carbon Radical}

B3LYP/def2TZVP opt=tight int=ultrafine
02
C $\quad-3.118495 \quad-2.310215 \quad 1.801278$
C $\quad-4.240745 \quad-1.480312 \quad 1.813625$
C $\quad-4.196798 \quad-0.206506 \quad 1.238167$
$\begin{array}{llll}\text { C } & -1.931608 & -1.893656 & 1.206750\end{array}$
C $\quad-3.023201 \quad 0.219190 \quad 0.642034$
$\begin{array}{llll}\text { C } & -0.801037 & 0.072729 & -0.041856\end{array}$
C $\quad-1.293135 \quad 1.378694 \quad-0.404215$
C $\quad-2.657365 \quad 1.479786 \quad-0.003723$
$\begin{array}{llll}\text { C } & -3.378725 & 2.632255 & -0.257960\end{array}$
$\begin{array}{llll}\text { C } & -2.748873 & 3.694130 & -0.915404\end{array}$
C $\quad-0.679731 \quad 2.443178 \quad-1.073891$
C $\quad-1.415990 \quad 3.597483 \quad-1.319536$
H $\quad-5.154252 \quad-1.823245 \quad 2.282115$
H $\quad-5.070489 \quad 0.432561 \quad 1.269294$
H $\quad-4.415827 \quad 2.719350 \quad 0.041283$
$\mathrm{H} \quad-3.304355 \quad 4.600758 \quad-1.118109$
H $\quad 0.348920 \quad 2.375517 \quad-1.403665$
$\mathrm{H} \quad-0.951430 \quad 4.429018 \quad-1.833420$
$\begin{array}{llll}\text { C } & 0.572430 & -0.406980 & -0.219025\end{array}$
$\begin{array}{llll}\text { C } & 0.904202 & -1.639526 & -0.821149\end{array}$
$\begin{array}{llll}\text { C } & 2.231825 & -2.070500 & -0.847698\end{array}$
$\begin{array}{llll}\text { C } & 3.248450 & -1.288755 & -0.329823\end{array}$
$\begin{array}{llll}\text { C } & 2.933576 & -0.054805 & 0.234625\end{array}$
$\begin{array}{llll}\text { C } & 1.618417 & 0.376665 & 0.291660\end{array}$
$\begin{array}{llll}\mathrm{H} & 2.460320 & -3.023912 & -1.302543\end{array}$ 


$\begin{array}{llll}\mathrm{H} & 4.272029 & -1.634418 & -0.367325 \\ \mathrm{C} & 4.042849 & 0.816672 & 0.761877 \\ \mathrm{H} & 1.381572 & 1.314476 & 0.772208 \\ \mathrm{C} & -0.077981 & -2.537772 & -1.514601 \\ \mathrm{O} & 0.013614 & -3.740896 & -1.500268 \\ \mathrm{O} & -1.061663 & -1.963269 & -2.230063 \\ \mathrm{H} & -3.170731 & -3.287515 & 2.263296 \\ \mathrm{C} & -1.880046 & -0.630489 & 0.609665 \\ \mathrm{H} & -1.065686 & -2.543047 & 1.218861 \\ \mathrm{~F} & 4.967600 & 0.102953 & 1.438544 \\ \mathrm{~F} & 3.599942 & 1.778761 & 1.592640 \\ \mathrm{~F} & 4.702671 & 1.442960 & -0.242413 \\ \mathrm{H} & -1.025722 & -0.995894 & -2.183077\end{array}$

Electronic Energy (0 K): -1257.95467001

Enthalpy (298.150 K): -1257.659324

Free Energy (298.150 K): -1257.732642 


\section{$5.17 \mathrm{~N}\left(\mathrm{Ar}_{\mathrm{Br}}\right)_{3} \mathrm{NBO}$ Analysis}

The following coordinates correspond to the SVP optimized geometry, achieved with the NoSymm keyword.

B3LYP/def2SVP pop=(nbo, savenbo $) \mathrm{SCRF}=(\mathrm{CPCM}$, Solvent $=$ Acetonitrile $)$
$\begin{array}{ll}0 & 1\end{array}$
$\mathrm{Br} \quad 5.874994 \quad 1.775193 \quad-0.000068$
$\mathrm{Br} \quad-4.475947 \quad 4.198424 \quad 0.000116$
$\begin{array}{llll}\mathrm{Br} & -1.399744 & -5.974389 & -0.000031\end{array}$
$\begin{array}{llll}\mathrm{N} & 0.000425 & 0.000518 & 0.000030\end{array}$
$\begin{array}{llll}\text { C } & 3.118927 & 1.891308 & 0.805493\end{array}$
$\begin{array}{llll}\text { C } & 4.044760 & 1.222228 & -0.000010\end{array}$
$\begin{array}{llll}\text { C } & 3.644165 & 0.152424 & -0.805461\end{array}$
$\begin{array}{llll}\text { C } & 2.305901 & -0.242686 & -0.809475\end{array}$
$\begin{array}{llll}\text { C } & 1.785734 & 1.479429 & 0.809612\end{array}$
$\begin{array}{llll}\text { C } & -3.081264 & 2.890602 & 0.000035\end{array}$
$\begin{array}{llll}\text { C } & -1.954954 & 3.078960 & -0.806010\end{array}$
$\begin{array}{llll}\text { C } & -3.196802 & 1.754453 & 0.805958\end{array}$
$\begin{array}{llll}\text { C } & -2.172861 & 0.806508 & 0.809951\end{array}$
$\begin{array}{llll}\text { C } & -0.943017 & 2.118146 & -0.810204\end{array}$
$\begin{array}{llll}\text { C } & 1.358581 & 0.410768 & 0.000093\end{array}$
$\begin{array}{llll}\text { C } & -1.034274 & 0.971273 & -0.000142\end{array}$
$\begin{array}{llll}\text { C } & -1.687884 & -3.231522 & -0.807610\end{array}$
$\begin{array}{llll}\text { C } & -0.963467 & -4.112853 & -0.000017\end{array}$
$\begin{array}{llll}\text { C } & 0.077077 & -3.645123 & 0.807591\end{array}$
$\begin{array}{llll}\text { C } & 0.386860 & -2.284575 & 0.811654\end{array}$
$\begin{array}{llll}\text { C } & -0.323293 & -1.380875 & 0.000050\end{array}$ 


$\begin{array}{llll}\mathrm{C} & -1.360975 & -1.874989 & -0.811612 \\ \mathrm{H} & 1.069162 & 1.993888 & 1.452169 \\ \mathrm{H} & 3.434284 & 2.720978 & 1.440424 \\ \mathrm{H} & 4.366051 & -0.363874 & -1.440498 \\ \mathrm{H} & 1.993956 & -1.067794 & -1.452070 \\ \mathrm{H} & -4.072589 & 1.612390 & 1.441356 \\ \mathrm{H} & -1.869647 & 3.962137 & -1.441350 \\ \mathrm{H} & -0.072881 & 2.260848 & -1.453264 \\ \mathrm{H} & -2.259195 & -0.071058 & 1.452942 \\ \mathrm{H} & -2.494534 & -3.598940 & -1.444223 \\ \mathrm{H} & 0.636484 & -4.332653 & 1.444241 \\ \mathrm{H} & 1.189102 & -1.920790 & 1.455950 \\ \mathrm{H} & -1.918064 & -1.192596 & -1.455849\end{array}$




\section{$5.18 \mathrm{~N}^{\bullet+}\left(\mathrm{Ar}_{\mathrm{Br}}\right)_{3} \mathrm{NBO}$ Analysis}

The following coordinates correspond to the SVP optimized geometry, achieved with the NoSymm keyword.

B3LYP/def2SVP pop $=($ nbo, savenbo $) \mathrm{SCRF}=(\mathrm{CPCM}$, Solvent $=$ Acetonitrile $)$

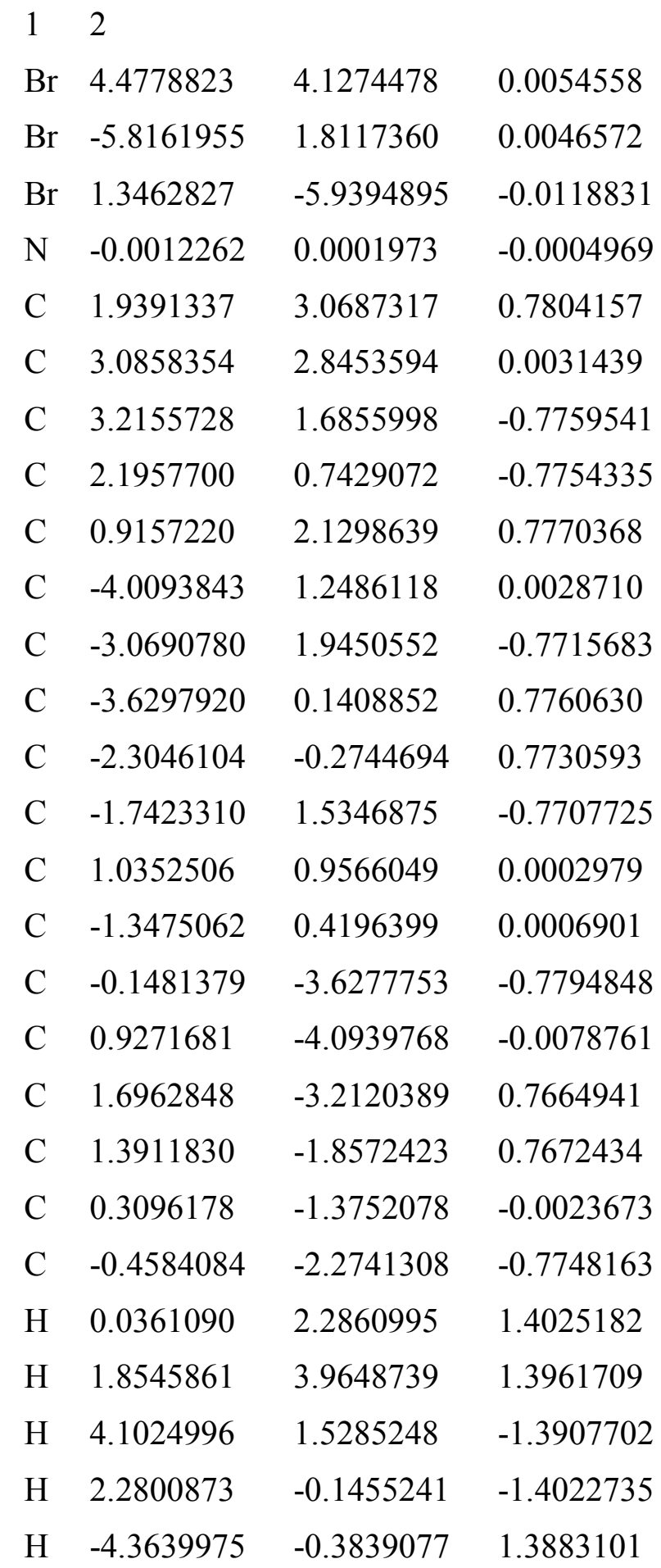




$\begin{array}{cccc}\mathrm{H} & -3.3765207 & 2.7940806 & -1.3830496 \\ \mathrm{H} & -1.0147364 & 2.0553608 & -1.3943748 \\ \mathrm{H} & -2.0003237 & -1.1167384 & 1.3953948 \\ \mathrm{H} & -0.7292210 & -4.3180299 & -1.3920112 \\ \mathrm{H} & 2.5194102 & -3.5856044 & 1.3765981 \\ \mathrm{H} & 1.9683124 & -1.1732279 & 1.3904220 \\ \mathrm{H} & -1.2747358 & -1.9042537 & -1.3962114\end{array}$




\section{$5.19 \operatorname{Flr}(\mathrm{H}) \mathrm{CO}_{2}{ }^{-}$and $\mathrm{N}^{\circ+}\left(\mathrm{Ar}_{\mathrm{Br}}\right)_{3}$}

Below are the coordinates and energies for the optimized structure of $\mathrm{Flr}(\mathrm{H}) \mathrm{CO}_{2}^{-}$and $\mathrm{N}^{\circ+}\left(\mathrm{Ar}_{\mathrm{Br}}\right)_{3}$. B3LYP/def2SVP freq=noraman

$\begin{array}{llll}\text { O } & 2 & & \\ \mathrm{C} & 6.561273 & -1.291701 & -2.474369 \\ \mathrm{C} & 7.752471 & -1.812147 & -1.945515 \\ \mathrm{C} & 7.997424 & -1.774017 & -0.567918 \\ \mathrm{C} & 5.596198 & -0.718884 & -1.633717 \\ \mathrm{C} & 7.036694 & -1.198475 & 0.273633 \\ \mathrm{C} & 4.953480 & -0.117634 & 0.845318 \\ \mathrm{C} & 5.795062 & -0.385483 & 2.083790 \\ \mathrm{C} & 7.004055 & -1.030880 & 1.735014 \\ \mathrm{C} & 7.924267 & -1.401750 & 2.723703 \\ \mathrm{C} & 7.628907 & -1.120751 & 4.062511 \\ \mathrm{C} & 5.507900 & -0.108627 & 3.420213 \\ \mathrm{C} & 6.430672 & -0.478772 & 4.409017 \\ \mathrm{H} & 6.383200 & -1.338184 & -3.552136 \\ \mathrm{H} & 8.494021 & -2.255571 & -2.615305 \\ \mathrm{H} & 8.923262 & -2.189193 & -0.160894 \\ \mathrm{H} & 8.859170 & -1.902810 & 2.459138 \\ \mathrm{H} & 8.338036 & -1.403122 & 4.845059 \\ \mathrm{H} & 4.577166 & 0.394177 & 3.696972 \\ \mathrm{H} & 6.214523 & -0.266012 & 5.459294 \\ \mathrm{C} & 4.528415 & 1.338222 & 0.645068 \\ \mathrm{C} & 3.219495 & 1.713115 & 0.260063 \\ \mathrm{C} & 2.920142 & 3.082890 & 0.127189 \\ \mathrm{C} & 3.883595 & 4.071292 & 0.321465 \\ \mathrm{C} & 5.181853 & 3.698656 & 0.687512 \\ \mathrm{C} & 5.486739 & 2.347907 & 0.855218 \\ \mathrm{H} & 1.895408 & 3.348566 & -0.138617 \\ \mathrm{H} & 3.624935 & 5.126148 & 0.194308 \\ \mathrm{H} & 5.952632 & 4.457105 & 0.849383\end{array}$




$\begin{array}{llll}\mathrm{H} & 6.497046 & 2.063018 & 1.161269 \\ \mathrm{C} & 2.080197 & 0.721729 & -0.039227 \\ \mathrm{O} & 0.914599 & 1.152228 & 0.141372 \\ \mathrm{O} & 2.402577 & -0.419566 & -0.467420 \\ \mathrm{C} & 5.842783 & -0.666658 & -0.262757 \\ \mathrm{H} & 4.655245 & -0.331916 & -2.030229 \\ \mathrm{H} & 4.032818 & -0.721302 & 0.862362 \\ \mathrm{Br} & 0.384145 & -4.621123 & -2.210990 \\ \mathrm{Br} & -8.686487 & 7-1.52345 & 42.258060 \\ \mathrm{Br} & -1.820439 & 95.637861 & -1.326680 \\ \mathrm{~N} & -3.396634 & -0.184827 & -0.459169 \\ \mathrm{C} & -2.178490 & -3.434697 & -1.769889 \\ \mathrm{C} & -0.790393 & -3.236476 & -1.666205 \\ \mathrm{C} & -0.262420 & -2.036799 & -1.170470 \\ \mathrm{C} & -1.125907 & -1.022961 & -0.773328 \\ \mathrm{C} & -3.043290 & -2.426719 & -1.369413 \\ \mathrm{C} & -2.575999 & -4.365002 & -2.177435 \\ \mathrm{C} & -7.041596 & -1.107717 & 1.413413 \\ \mathrm{C} & -5.892154 & -1.840631 & 1.741589 \\ \mathrm{C} & -6.991925 & -0.070473 & 0.470828 \\ \mathrm{C} & -5.785290 & 0.236448 & -0.146626 \\ \mathrm{C} & -4.686213 & -1.537522 & 1.120643 \\ \mathrm{C} & -2.524189 & -1.209176 & -0.865729 \\ \mathrm{C} & -4.622500 & -0.496613 & 0.170555 \\ \mathrm{C} & -2.944706 & 3.454020 & 0.136996 \\ \mathrm{C} & -2.321644 & 3.829479 & -1.062136 \\ \mathrm{C} & -2.061516 & 2.886720 & -2.067008 \\ \mathrm{C} & -1.850819 & -1.061832\end{array}$




$\begin{array}{llll}\mathrm{H} & -0.670530 & -0.108772 & -0.366363 \\ \mathrm{H} & -7.893871 & 0.485012 & 0.211258 \\ \mathrm{H} & -5.936043 & -2.633708 & 2.488925 \\ \mathrm{H} & -3.783574 & -2.085284 & 1.393835 \\ \mathrm{H} & -5.747112 & 1.024747 & -0.899486 \\ \mathrm{H} & -3.129981 & 4.191678 & 0.918571 \\ \mathrm{H} & -1.593358 & 3.191069 & -3.003779 \\ \mathrm{H} & -2.242646 & 0.826696 & -2.656862 \\ \mathrm{H} & -3.765679 & 1.825609 & 1.276294\end{array}$

Electronic Energy (0 K): -9388.71391089

Enthalpy (298.150 K): -9388.155293

Free Energy (298.150 K): -9388.277094 


\section{$5.20 \operatorname{Flr}\left(\mathrm{C}_{\bullet}\right) \mathrm{CO}_{2} \mathrm{H}$ and $\mathrm{N}\left(\mathrm{Ar}_{\mathrm{Br}}\right)_{3}$}

Below are the coordinates and energies for the optimized structure of $\mathrm{Flr}\left(\mathrm{C} \bullet \mathrm{CO}_{2} \mathrm{H}\right.$ and $\mathrm{N}\left(\mathrm{Ar} \mathrm{Br}_{3}\right.$. B3LYP/def2SVP freq=noraman

\begin{tabular}{|c|c|c|c|}
\hline 0 & 2 & & \\
\hline $\mathrm{C}$ & 8.196197 & -0.809568 & -1.393314 \\
\hline $\mathrm{C}$ & 8.452754 & -2.033186 & -0.754774 \\
\hline $\mathrm{C}$ & 7.691903 & -2.440948 & 0.355197 \\
\hline $\mathrm{C}$ & 7.179316 & 0.036065 & -0.937673 \\
\hline $\mathrm{C}$ & 6.679491 & -1.607766 & 0.820986 \\
\hline $\mathrm{C}$ & 5.305948 & 0.290210 & 0.849547 \\
\hline $\mathrm{C}$ & 4.892104 & -0.583428 & 1.932803 \\
\hline $\mathrm{C}$ & 5.725127 & -1.747565 & 1.927775 \\
\hline $\mathrm{C}$ & 5.551605 & -2.743691 & 2.884311 \\
\hline $\mathrm{C}$ & 4.550090 & -2.585918 & 3.857940 \\
\hline $\mathrm{C}$ & 3.905028 & -0.430892 & 2.922134 \\
\hline $\mathrm{C}$ & 3.740003 & -1.439704 & 3.877070 \\
\hline $\mathrm{H}$ & 8.795237 & -0.515883 & -2.258567 \\
\hline $\mathrm{H}$ & 9.250642 & -2.680089 & -1.127461 \\
\hline $\mathrm{H}$ & 7.897228 & -3.399634 & 0.838010 \\
\hline $\mathrm{H}$ & 6.184461 & -3.634645 & 2.887968 \\
\hline $\mathrm{H}$ & 4.405450 & -3.362407 & 4.612986 \\
\hline $\mathrm{H}$ & 3.276674 & 0.462123 & 2.956409 \\
\hline $\mathrm{H}$ & 2.974126 & -1.331918 & 4.648751 \\
\hline $\mathrm{C}$ & 4.784995 & 1.635988 & 0.556980 \\
\hline $\mathrm{C}$ & 3.406846 & 1.931775 & 0.361959 \\
\hline $\mathrm{C}$ & 2.995317 & 3.265873 & 0.204773 \\
\hline $\mathrm{C}$ & 3.917813 & 4.310274 & 0.194791 \\
\hline $\mathrm{C}$ & 5.278665 & 4.026465 & 0.347544 \\
\hline $\mathrm{C}$ & 5.701183 & 2.709950 & 0.527498 \\
\hline $\mathrm{H}$ & 1.932041 & 3.466336 & 0.064958 \\
\hline $\mathrm{H}$ & 3.577023 & 5.339112 & 0.060143 \\
\hline $\mathrm{H}$ & 6.014833 & 4.833788 & 0.339729 \\
\hline
\end{tabular}




\begin{tabular}{|c|c|c|c|}
\hline 11 & 6.760286 & 2.501351 & 0.689006 \\
\hline$C$ & 2.314844 & 0.905668 & 0.232681 \\
\hline O & 1.152489 & 1.158233 & 0.465149 \\
\hline$\Omega$ & 2.641250 & -0.317594 & -0.215744 \\
\hline $\mathrm{C}$ & 6.419164 & -0.353337 & 0.180191 \\
\hline $\mathrm{H}$ & 6.979375 & 0.980568 & -1.448244 \\
\hline 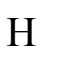 & 3.598398 & -0.401587 & -0.368328 \\
\hline $\mathrm{D}$ & 0.259030 & -4.827672 & -2.364701 \\
\hline $\mathrm{P}$ & -8.783076 & -1.05631 & 51.856942 \\
\hline $\mathrm{Br}$ & -1.000229 & 5.589037 & -1.072634 \\
\hline $\mathrm{N}$ & -3.239036 & -0.104261 & -0.596245 \\
\hline C & -2.208198 & -3.384930 & -2.055524 \\
\hline $\mathrm{C}$ & -0.831932 & -3.355660 & -1.812952 \\
\hline $\mathrm{C}$ & -0.245947 & -2.260365 & -1.172902 \\
\hline $\mathrm{C}$ & -1.045135 & -1.192331 & -0.762378 \\
\hline $\mathrm{C}$ & -2.999696 & -2.305458 & -1.660272 \\
\hline $\mathrm{C}$ & -7.055367 & -0.761317 & 1.092435 \\
\hline $\mathrm{C}$ & -5.991729 & -1.599056 & 1.439698 \\
\hline $\mathrm{C}$ & -6.866773 & 0.290338 & 0.191302 \\
\hline $\mathrm{C}$ & -5.606649 & 0.496976 & -0.371154 \\
\hline $\mathrm{C}$ & -4.730281 & -1.375666 & 0.886627 \\
\hline $\mathrm{C}$ & -2.431678 & -1.197938 & -1.003390 \\
\hline $\mathrm{C}$ & -4.519376 & -0.328720 & -0.029797 \\
\hline $\mathrm{C}$ & -2.389657 & 3.437816 & 0.231637 \\
\hline $\mathrm{C}$ & -1.719569 & 3.822163 & -0.932946 \\
\hline $\mathrm{C}$ & -1.562337 & 2.925480 & -1.993658 \\
\hline $\mathrm{C}$ & -2.080980 & 1.634928 & -1.884638 \\
\hline $\mathrm{C}$ & -2.742014 & 1.220188 & -0.714277 \\
\hline $\mathrm{C}$ & -2.890085 & 2.139588 & 0.339788 \\
\hline $\mathrm{H}$ & -4.070965 & -2.325109 & -1.867863 \\
\hline $\mathrm{H}$ & -2.663837 & -4.236148 & -2.564361 \\
\hline $\mathrm{H}$ & 0.827390 & -2.228801 & -0.977965 \\
\hline
\end{tabular}




$\begin{array}{llll}\mathrm{H} & -0.571800 & -0.348669 & -0.255574 \\ \mathrm{H} & -7.699551 & 0.939025 & -0.085543 \\ \mathrm{H} & -6.137633 & -2.414290 & 2.150403 \\ \mathrm{H} & -3.899087 & -2.021935 & 1.173532 \\ \mathrm{H} & -5.466937 & 1.309140 & -1.086689 \\ \mathrm{H} & -2.506247 & 4.137605 & 1.060849 \\ \mathrm{H} & -1.048774 & 3.231425 & -2.906641 \\ \mathrm{H} & -1.966650 & 0.939414 & -2.717872 \\ \mathrm{H} & -3.394669 & 1.835369 & 1.258480\end{array}$

Electronic Energy (0 K): -9388.74391276

Enthalpy (298.150 K): -9388.185191

Free Energy (298.150 K): -9388.309789 


\section{$5.21 \mathrm{~N}(\mathrm{Ph})_{3} \mathrm{NBO}$ Analysis}

The following coordinates correspond to the SVP optimized geometry, achieved with the NoSymm keyword.

B3LYP/def2SVP pop=(nbo,savenbo $) \mathrm{SCRF}=(\mathrm{CPCM}$, Solvent=Acetonitrile $)$

$\begin{array}{llll}\text { O } & 1 & & \\ \mathrm{H} & -2.8755339 & 4.4927106 & 0.0030277 \\ \mathrm{H} & -2.4536962 & -4.7377005 & -0.0038665 \\ \mathrm{H} & 5.3297522 & 0.2459891 & 0.0117061 \\ \mathrm{~N} & 0.0004390 & -0.0006866 & 0.0001576 \\ \mathrm{C} & -2.6616475 & 2.4908323 & 0.8073410 \\ \mathrm{C} & -2.2866967 & 3.5724430 & 0.0022763 \\ \mathrm{C} & -1.1482195 & 3.4605541 & -0.8039097 \\ \mathrm{C} & -0.3974901 & 2.2830216 & -0.8140778 \\ \mathrm{C} & -1.9068398 & 1.3159175 & 0.8157015 \\ \mathrm{C} & -1.9510938 & -3.7676389 & -0.0029963 \\ \mathrm{C} & -2.4246494 & -2.7236461 & -0.8057463 \\ \mathrm{C} & -0.8257932 & -3.5534514 & 0.8009746 \\ \mathrm{C} & -0.1855220 & -2.3124231 & 0.8114152 \\ \mathrm{C} & -1.7800917 & -1.4848196 & -0.8139768 \\ \mathrm{C} & -0.7654775 & 1.1954437 & 0.0005211 \\ \mathrm{C} & -0.6527289 & -1.2617312 & -0.0008052 \\ \mathrm{C} & 3.5741116 & -0.7377472 & -0.7946367 \\ \mathrm{C} & 4.2383954 & 0.1954918 & 0.0093299 \\ \mathrm{C} & 3.4872117 & 1.0631932 & 0.8101542 \\ \mathrm{C} & 2.0923226 & 0.9961771 & 0.8163858 \\ \mathrm{C} & 1.4190731 & 0.0648694 & 0.0031377 \\ \mathrm{H} & 2.1790457 & -0.8000147 & -0.8070647 \\ \mathrm{H} & -2.1993492 & 0.4833931 & 1.4583786 \\ \mathrm{H} & -3.5443123 & 2.5647120 & 1.4481040 \\ \mathrm{H} & -0.8461012 & 4.2936940 & -1.4440239 \\ \mathrm{H} & -0.4805737 & 2.2006000 & -1.4574532 \\ \mathrm{H} & -4.3563400 & 1.4392952\end{array}$




$\begin{array}{llll}\mathrm{H} & -3.2983012 & -2.8768054 & -1.4448320 \\ \mathrm{H} & -2.1486756 & -0.6816980 & -1.4549391 \\ \mathrm{H} & 0.6826178 & -2.1512960 & 1.4533069 \\ \mathrm{H} & 4.1460117 & -1.4179108 & -1.4313952 \\ \mathrm{H} & 3.9909293 & 1.7932283 & 1.4492685 \\ \mathrm{H} & 1.5162851 & 1.6677511 & 1.4557738 \\ \mathrm{H} & 1.6704221 & -1.5218454 & -1.4488945\end{array}$




\section{$5.22 \mathrm{~N}^{\bullet+}(\mathrm{Ph})_{3} \mathrm{NBO}$ Analysis}

The following coordinates correspond to the SVP optimized geometry, achieved with the NoSymm keyword.

B3LYP/def2SVP pop=(nbo,savenbo $) \mathrm{SCRF}=(\mathrm{CPCM}$, Solvent=Acetonitrile $)$

$\begin{array}{llll}\text { I } & 2 & & \\ \mathrm{H} & -2.8546790 & 4.4617350 & 0.0049530 \\ \mathrm{H} & -2.4390660 & -4.7045890 & -0.0034670 \\ \mathrm{H} & 5.2933310 & 0.2465910 & 0.0112850 \\ \mathrm{~N} & 0.0007430 & -0.0013830 & -0.0000470 \\ \mathrm{C} & -2.6798640 & 2.4459060 & 0.7742070 \\ \mathrm{C} & -2.2663790 & 3.5416660 & 0.0033860 \\ \mathrm{C} & -1.0994300 & 3.4588210 & -0.7694510 \\ \mathrm{C} & -0.3422120 & 2.2922280 & -0.7744330 \\ \mathrm{C} & -1.9384490 & 1.2692330 & 0.7758050 \\ \mathrm{C} & -1.9359330 & -3.7352920 & -0.0030310 \\ \mathrm{C} & -2.4479840 & -2.6810220 & -0.7725920 \\ \mathrm{C} & -0.7794280 & -3.5478120 & 0.7671940 \\ \mathrm{C} & -0.1307100 & -2.3176770 & 0.7714380 \\ \mathrm{C} & -1.8156360 & -1.4423630 & -0.7752680 \\ \mathrm{C} & -0.7605160 & 1.1873550 & 0.0002480 \\ \mathrm{C} & -0.6485380 & -1.2544590 & -0.0015570 \\ \mathrm{C} & 3.5495320 & -0.7784110 & -0.7598370 \\ \mathrm{C} & 4.2024590 & 0.1953800 & 0.0091460 \\ \mathrm{C} & 3.4578840 & 1.1034680 & 0.7752390 \\ \mathrm{C} & 2.0683060 & 1.0474130 & 0.7755660 \\ \mathrm{H} & 1.4104680 & 0.0641550 & 0.0030740 \\ \mathrm{H} & 2.1608200 & -0.8530300 & -0.7662880 \\ \mathrm{H} & -2.2404570 & 0.4255590 & 1.3974330 \\ \mathrm{H} & -3.5797080 & 2.5156320 & 1.3885350 \\ \mathrm{H} & -0.54863400 & 4.3063060 & -1.3824320 \\ \mathrm{H} & -1.3973290 \\ \mathrm{H} & -2.2136540 & 1.3790850\end{array}$




$\begin{array}{llll}\mathrm{H} & -3.3393040 & -2.8314770 & -1.3849170 \\ \mathrm{H} & -2.1939220 & -0.6292310 & -1.3957960 \\ \mathrm{H} & 0.7513350 & -2.1594250 & 1.3929520 \\ \mathrm{H} & 4.1285730 & -1.4752970 & -1.3689920 \\ \mathrm{H} & 3.9663750 & 1.8514790 & 1.3867190 \\ \mathrm{H} & 1.4870080 & 1.7328300 & 1.3932900 \\ \mathrm{H} & 1.6493400 & -1.5899300 & -1.3864790\end{array}$




\section{$5.23 \operatorname{Fr}(\mathrm{H}) \mathrm{CO}_{2}{ }^{-}$and $\mathrm{N}^{\circ+}(\mathrm{Ph})_{3}$}

Below are the coordinates and energies for the optimized structure of $\mathrm{Flr}(\mathrm{H}) \mathrm{CO}_{2}{ }^{-}$and $\mathrm{N}^{\circ+}(\mathrm{Ph})_{3}$. B3LYP/def2SVP freq=noraman

$\begin{array}{llll}\text { O } & 2 & & \\ \mathrm{H} & 5.144569 & -1.292332 & -3.124097 \\ \mathrm{H} & 6.383193 & -1.789088 & -2.689790 \\ \mathrm{H} & 6.736783 & -1.738429 & -1.336402 \\ \mathrm{~N} & 4.239865 & -0.731433 & -2.211384 \\ \mathrm{C} & 5.836358 & -1.174636 & -0.423267 \\ \mathrm{C} & 3.785947 & -0.128215 & 0.307959 \\ \mathrm{C} & 4.728913 & -0.371450 & 1.476158 \\ \mathrm{C} & 5.917904 & -0.997494 & 1.035012 \\ \mathrm{C} & 6.921410 & -1.344381 & 1.948495 \\ \mathrm{C} & 6.729671 & -1.058738 & 3.305044 \\ \mathrm{C} & 4.545246 & -0.090031 & 2.829818 \\ \mathrm{C} & 5.551406 & -0.436019 & 3.743154 \\ \mathrm{C} & 4.881929 & -1.347873 & -4.183991 \\ \mathrm{C} & 7.076644 & -2.223489 & -3.414742 \\ \mathrm{C} & 7.699553 & -2.134767 & -1.002894 \\ \mathrm{C} & 7.841158 & -1.830353 & 1.612290 \\ \mathrm{C} & 7.504623 & -1.322370 & 4.029564 \\ \mathrm{C} & 3.630595 & 0.397860 & 3.177764 \\ \mathrm{C} & 5.416624 & -0.219306 & 4.806145 \\ \mathrm{C} & 3.317261 & 1.317346 & 0.133517 \\ \mathrm{C} & 1.971732 & 1.664303 & -0.132556 \\ \mathrm{C} & 1.637743 & 3.026854 & -0.257052 \\ \mathrm{H} & 2.597030 & 4.033951 & -0.165719 \\ \mathrm{H} & 3.929806 & 3.688573 & 0.085540 \\ \mathrm{H} & 4.272790 & 2.345700 & 0.241974 \\ \mathrm{H} & 0.587857 & 3.270087 & -0.430200 \\ \mathrm{H} & 2.309150 & 5.082365 & -0.283327 \\ \mathrm{H} & 4.698402 & 4.462100 & 0.166198 \\ & & & \\ & & & \end{array}$




$\begin{array}{llll}\mathrm{H} & 5.311987 & 2.081751 & 0.456717 \\ \mathrm{H} & 0.824831 & 0.650187 & -0.307224 \\ \mathrm{H} & -0.325545 & 1.070994 & -0.031713 \\ \mathrm{H} & 1.124415 & -0.496252 & -0.736870 \\ \mathrm{H} & 4.593943 & -0.667140 & -0.864723 \\ \mathrm{H} & 3.264245 & -0.362089 & -2.534295 \\ \mathrm{C} & 2.880504 & -0.748509 & 0.399575 \\ \mathrm{C} & -1.583689 & -4.267172 & -1.825152 \\ \mathrm{C} & -8.953318 & -1.331164 & 2.809274 \\ \mathrm{C} & -3.472842 & 4.706666 & -1.373749 \\ \mathrm{C} & -4.674595 & -0.308223 & -0.149270 \\ \mathrm{C} & -3.611180 & -3.627284 & -1.414681 \\ \mathrm{C} & -2.219177 & -3.447938 & -1.480288 \\ \mathrm{C} & -1.647873 & -2.223573 & -1.106771 \\ \mathrm{C} & -2.452420 & -1.175594 & -0.668867 \\ \mathrm{C} & -4.431055 & -2.595882 & -0.974409 \\ \mathrm{C} & -8.071920 & -1.120752 & 2.199647 \\ \mathrm{C} & -6.880829 & -1.823776 & 2.425811 \\ \mathrm{H} & -8.133394 & -0.147056 & 1.193219 \\ \mathrm{H} & -7.013762 & 0.129915 & 0.414646 \\ \mathrm{H} & -5.753890 & -1.563545 & 1.651784 \\ \mathrm{H} & -3.852804 & -1.359004 & -0.597558 \\ \mathrm{H} & -5.816177 & -0.582030 & 0.639619 \\ \mathrm{H} & -4.195745 & 3.360174 & 0.159588 \\ \mathrm{H} & -3.721157 & 3.673369 & -1.121909 \\ \mathrm{C} & -3.566039 & 2.662709 & -2.080584 \\ \mathrm{C} & -3.878428 & 1.343743 & -1.767111 \\ \mathrm{C} & -4.356800 & 1.028839 & -0.476964 \\ \mathrm{C} & -4.517910 & 2.047175 & 0.487481 \\ \mathrm{C} & -5.514256 & -2.720983 & -0.953808 \\ \mathrm{H} & -4.057712 & -4.574486 & -1.724463 \\ & -0.567905 & -2.046324 & -1.128305\end{array}$




$\begin{array}{llll}\mathrm{H} & -1.963143 & -0.243026 & -0.357506 \\ \mathrm{H} & -9.064805 & 0.391486 & 1.006992 \\ \mathrm{H} & -6.826914 & -2.570974 & 3.220184 \\ \mathrm{C} & -4.817033 & -2.087973 & 1.843512 \\ \mathrm{O} & -7.065228 & 0.868691 & -0.386097 \\ \mathrm{O} & -4.302755 & 4.144464 & 0.911665 \\ \mathrm{C} & -3.211387 & 2.907878 & -3.083732 \\ \mathrm{H} & -3.785803 & 0.559139 & -2.518737 \\ \mathrm{H} & -4.860331 & 1.795893 & 1.492017\end{array}$

Electronic Energy (0 K): -1668.91390589

Enthalpy (298.150 K): -1668.328859

Free Energy (298.150 K): -1668.434975 


\section{$5.24 \operatorname{Flr}\left(\mathrm{C} \bullet \mathrm{CO}_{2} \mathrm{H}\right.$ and $\mathrm{N}(\mathrm{Ph})_{3}$}

Below are the coordinates and energies for the optimized structure of $\mathrm{Flr}\left(\mathrm{C} \bullet \mathrm{CO}_{2} \mathrm{H}\right.$ and $\mathrm{N}(\mathrm{Ph})_{3}$. B3LYP/def2SVP freq=noraman

\begin{tabular}{llll}
$\mathrm{O}$ & 2 & & \\
$\mathrm{H}$ & 6.977503 & -0.219571 & -2.277068 \\
$\mathrm{H}$ & 7.316457 & -1.532262 & -1.912731 \\
$\mathrm{H}$ & 6.657905 & -2.179386 & -0.852159 \\
$\mathrm{~N}$ & 5.978289 & 0.478246 & -1.590535 \\
$\mathrm{C}$ & 5.664247 & -1.495615 & -0.158468 \\
$\mathrm{C}$ & 4.248091 & 0.302117 & 0.344108 \\
$\mathrm{C}$ & 3.946088 & -0.781364 & 1.262108 \\
$\mathrm{C}$ & 4.805994 & -1.887001 & 0.966624 \\
$\mathrm{C}$ & 4.735902 & -3.055948 & 1.718924 \\
$\mathrm{C}$ & 3.812271 & -3.131225 & 2.775910 \\
$\mathrm{C}$ & 3.037923 & -0.864295 & 2.331959 \\
$\mathrm{C}$ & 2.976713 & -2.044927 & 3.079668 \\
$\mathrm{C}$ & 7.497627 & 0.261516 & -3.108807 \\
$\mathrm{C}$ & 8.098943 & -2.060525 & -2.462877 \\
$\mathrm{C}$ & 6.926760 & -3.204125 & -0.583897 \\
$\mathrm{C}$ & 5.390036 & -3.903846 & 1.500911 \\
$\mathrm{C}$ & 3.749230 & -4.044606 & 3.372321 \\
$\mathrm{C}$ & 2.391172 & -0.021463 & 2.586623 \\
$\mathrm{C}$ & 2.272867 & -2.120597 & 3.911864 \\
$\mathrm{C}$ & 3.671125 & 1.656939 & 0.362540 \\
$\mathrm{C}$ & 2.275084 & 1.929598 & 0.326282 \\
$\mathrm{C}$ & 1.819052 & 3.250854 & 0.468037 \\
$\mathrm{H}$ & 2.710817 & 4.312987 & 0.603651 \\
$\mathrm{H}$ & 4.086201 & 4.059525 & 0.601252 \\
$\mathrm{H}$ & 4.554697 & 2.751504 & 0.484308 \\
$\mathrm{H}$ & 0.742863 & 3.428955 & 0.445405 \\
$\mathrm{H}$ & 2.335296 & 5.333790 & 0.702397 \\
$\mathrm{H}$ & 4.798740 & 4.881430 & 0.703847 \\
& & & \\
\hline
\end{tabular}




$\begin{array}{llll}\mathrm{H} & 5.628049 & 2.557826 & 0.526314 \\ \mathrm{H} & 1.201054 & 0.907807 & 0.069107 \\ \mathrm{H} & 0.050750 & 1.072688 & 0.412464 \\ \mathrm{H} & 1.526408 & -0.197499 & -0.620771 \\ \mathrm{H} & 5.320397 & -0.152534 & -0.518959 \\ \mathrm{H} & 5.713609 & 1.495100 & -1.888455 \\ \mathrm{C} & 2.473675 & -0.217901 & -0.841509 \\ \mathrm{C} & -1.517452 & -3.824225 & -2.898998 \\ \mathrm{C} & -8.934566 & -1.656559 & 2.186181 \\ \mathrm{C} & -3.022902 & 4.944109 & -0.446628 \\ \mathrm{C} & -4.513906 & -0.178481 & -0.409367 \\ \mathrm{C} & -3.527250 & -3.137385 & -2.464306 \\ \mathrm{C} & -2.130884 & -3.077567 & -2.388896 \\ \mathrm{C} & -1.531316 & -2.049143 & -1.652862 \\ \mathrm{C} & -2.311410 & -1.097524 & -0.991629 \\ \mathrm{C} & -4.315365 & -2.180041 & -1.821372 \\ \mathrm{C} & -8.029216 & -1.354136 & 1.654657 \\ \mathrm{C} & -6.866831 & -2.129165 & 1.736946 \\ \mathrm{H} & -8.017116 & -0.186819 & 0.882774 \\ \mathrm{H} & -6.864546 & 0.198547 & 0.194877 \\ \mathrm{H} & -5.705028 & -1.741945 & 1.065780 \\ \mathrm{H} & -3.715773 & -1.150102 & -1.071837 \\ \mathrm{H} & -5.689867 & -0.572965 & 0.281142 \\ \mathrm{H} & -3.820321 & 3.308990 & 0.733080 \\ \mathrm{H} & -3.328830 & 3.895303 & -0.438926 \\ \mathrm{C} & -3.236200 & 3.121363 & -1.601586 \\ \mathrm{C} & -3.635523 & 1.783324 & -1.598339 \\ \mathrm{C} & -4.121129 & 1.186088 & -0.419599 \\ \mathrm{C} & -4.205621 & 1.966751 & 0.748839 \\ \mathrm{C} & -5.403281 & -2.227267 & -1.899304 \\ \mathrm{H} & -4.011774 & -3.929657 & -3.041292 \\ & -0.442955 & -1.982231 & -1.575689\end{array}$




$\begin{array}{llll}\mathrm{H} & -1.822068 & -0.310225 & -0.414659 \\ \mathrm{H} & -8.918780 & 0.426118 & 0.802138 \\ \mathrm{H} & -6.857354 & -3.040040 & 2.341451 \\ \mathrm{C} & -4.799629 & -2.346054 & 1.148623 \\ \mathrm{O} & -6.870283 & 1.103055 & -0.416319 \\ \mathrm{O} & -3.892990 & 3.897680 & 1.651413 \\ \mathrm{C} & -2.861930 & 3.566218 & -2.527444 \\ \mathrm{H} & -3.571733 & 1.192165 & -2.513815 \\ \mathrm{H} & -4.572601 & 1.515095 & 1.672417\end{array}$

Electronic Energy (0 K): -1668.93986701

Enthalpy (298.150 K): -1668.354891

Free Energy (298.150 K): -1668.464333 


\subsection{TS for Intramolecular Proton Transfer in $\mathrm{Flr}(\mathrm{H}) \mathrm{CO}_{2}^{-}$}

These keywords were used on the following set of coordinates, which are an estimate of the transition state structure.

B3LYP/def2-SVP opt=(calcfc, ts, noeigentest $)$ freq=noraman

$\begin{array}{llll}-1 & 1 & & \\ \mathrm{C} & -1.4909374 & -3.4748784 & 0.3794249 \\ \mathrm{C} & -2.8551973 & -3.1235282 & 0.3161162 \\ \mathrm{C} & -3.2298243 & -1.7854592 & 0.1721101 \\ \mathrm{C} & -0.4917884 & -2.5034062 & 0.2898213 \\ \mathrm{C} & -2.2386806 & -0.7939716 & 0.0943696 \\ \mathrm{C} & -0.0283632 & 0.0493295 & -0.0460312 \\ \mathrm{C} & -0.9787668 & 1.1625471 & -0.0480858 \\ \mathrm{C} & -2.3193088 & 0.6535974 & -0.0249107 \\ \mathrm{C} & -3.4144843 & 1.5287216 & -0.1037099 \\ \mathrm{C} & -3.1908806 & 2.9055918 & -0.1796192 \\ \mathrm{C} & -0.7735330 & 2.5545417 & -0.1182086 \\ \mathrm{C} & -1.8743690 & 3.4113071 & -0.1799040 \\ \mathrm{H} & -1.2117730 & -4.5259095 & 0.5004695 \\ \mathrm{H} & -3.6203646 & -3.9017100 & 0.3837250 \\ \mathrm{H} & -4.2892714 & -1.5140464 & 0.1289035 \\ \mathrm{H} & -4.4370626 & 1.1385590 & -0.0964690 \\ \mathrm{H} & -4.0377116 & 3.5951785 & -0.2343712 \\ \mathrm{H} & 0.2413358 & 2.9634228 & -0.1245090 \\ \mathrm{H} & -1.7142116 & 4.4925285 & -0.2306986 \\ \mathrm{C} & 1.3621452 & 0.1673503 & 0.5156571 \\ \mathrm{C} & 2.5004362 & -0.0054481 & -0.3087601 \\ \mathrm{C} & 3.7901341 & 0.0881120 & 0.2412997 \\ \mathrm{H} & 3.9729860 & 0.3588854 & 1.5961200 \\ \mathrm{H} & 2.8538589 & 0.5431427 & 2.4188038 \\ \mathrm{H} & 4.5692308 & 0.4468069 & 1.8806003 \\ \mathrm{H} & -0.4254773 \\ \mathrm{H} & -0.0527730 & 2.0126235\end{array}$




$\begin{array}{llll}\mathrm{H} & 2.9845007 & 0.7590472 & 3.4829462 \\ \mathrm{H} & 0.6979653 & 0.5869629 & 2.5261812 \\ \mathrm{C} & 2.3874586 & -0.2624347 & -1.8025746 \\ \mathrm{O} & 3.3920588 & -0.4182446 & -2.4897813 \\ \mathrm{O} & 1.1783582 & -0.2924228 & -2.2935004 \\ \mathrm{C} & -0.8505740 & -1.1496805 & 0.1404728 \\ \mathrm{H} & 0.5620735 & -2.7939639 & 0.3365314 \\ \mathrm{H} & 0.4397686 & -0.1184669 & -1.3915524\end{array}$

The following coordinates are the result of the transition state search and contain only a single imaginary frequency. This frequency corresponds to movement of the fluorenyl proton between the fluorenyl carbon and carboxylate oxygen.

$\begin{array}{llll}-1 & 1 & & \\ \mathrm{C} & -1.5337770 & 3.4751970 & -0.3130730 \\ \mathrm{C} & -2.8930940 & 3.1050610 & -0.2651100 \\ \mathrm{C} & -3.2513240 & 1.7599500 & -0.1449760 \\ \mathrm{C} & -0.5225980 & 2.5148730 & -0.2312770 \\ \mathrm{C} & -2.2473550 & 0.7811540 & -0.0758330 \\ \mathrm{C} & -0.0250790 & -0.0364280 & 0.0708230 \\ \mathrm{C} & -0.9652200 & -1.1626160 & 0.0441920 \\ \mathrm{C} & -2.3103400 & -0.6702150 & 0.0193590 \\ \mathrm{C} & -3.3953600 & -1.5593330 & 0.0744740 \\ \mathrm{C} & -3.1547990 & -2.9346010 & 0.1282060 \\ \mathrm{C} & -0.7422240 & -2.5518380 & 0.0918560 \\ \mathrm{C} & -1.8327140 & -3.4238340 & 0.1299410 \\ \mathrm{H} & -1.2675050 & 4.5315030 & -0.4153310 \\ \mathrm{H} & -3.6680590 & 3.8740280 & -0.3259690 \\ \mathrm{H} & -4.3072930 & 1.4740230 & -0.1137850 \\ \mathrm{H} & -4.4225910 & -1.1818140 & 0.0658240 \\ \mathrm{H} & -3.9933450 & -3.6354330 & 0.1641950 \\ \mathrm{H} & 0.2777610 & -2.9476940 & 0.0988770 \\ \mathrm{H} & -1.6592530 & -4.5036370 & 0.1630050\end{array}$




$\begin{array}{llll}\mathrm{C} & 1.3581390 & -0.1307900 & -0.5171920 \\ \mathrm{C} & 2.5046290 & 0.0030570 & 0.3020680 \\ \mathrm{C} & 3.7879720 & -0.0730670 & -0.2650590 \\ \mathrm{C} & 3.9551810 & -0.2863210 & -1.6322780 \\ \mathrm{C} & 2.8267610 & -0.4281960 & -2.4507830 \\ \mathrm{C} & 1.5482260 & -0.3498510 & -1.8952490 \\ \mathrm{H} & 4.6482860 & 0.0358690 & 0.3980780 \\ \mathrm{H} & 4.9586670 & -0.3443820 & -2.0621330 \\ \mathrm{H} & 2.9454870 & -0.5978280 & -3.5246690 \\ \mathrm{H} & 0.6694410 & -0.4580530 & -2.5368880 \\ \mathrm{C} & 2.4045610 & 0.2065330 & 1.8065950 \\ \mathrm{O} & 3.4192490 & 0.3316020 & 2.4874900 \\ \mathrm{O} & 1.2016310 & 0.2282330 & 2.3053940 \\ \mathrm{C} & -0.8651350 & 1.1554430 & -0.1062210 \\ \mathrm{H} & 0.5277470 & 2.8195550 & -0.2653710 \\ \mathrm{H} & 0.4449140 & 0.0901170 & 1.3883330\end{array}$

$\begin{array}{lll}\# & \text { frequency } & v\left(\mathrm{~cm}^{-1}\right) \\ 1 & -1160.80 & 10942.2428 \\ 2 & 13.22 & 3.2983 \\ 3 & 57.23 & 1.1269 \\ 4 & 59.47 & 0.1843 \\ 5 & 103.20 & 0.6406 \\ 6 & 104.57 & 2.6118 \\ 7 & 129.90 & 1.5904 \\ 8 & 148.23 & 0.1141 \\ 9 & 167.97 & 1.2015 \\ 10 & 236.35 & 1.7249 \\ 11 & 250.86 & 0.1191 \\ 12 & 271.13 & 1.0719 \\ 13 & 301.70 & 0.5521 \\ 14 & 338.53 & 12.7791\end{array}$




$\begin{array}{lll}15 & 429.50 & 3.2574 \\ 16 & 441.20 & 7.0998 \\ 17 & 442.89 & 4.9044 \\ 18 & 457.98 & 0.5161 \\ 19 & 473.66 & 1.3619 \\ 20 & 495.22 & 4.4921 \\ 21 & 507.28 & 0.9659 \\ 22 & 527.50 & 9.9094 \\ 23 & 549.12 & 5.0411 \\ 24 & 596.59 & 0.0723 \\ 25 & 625.84 & 0.5344 \\ 26 & 633.30 & 18.9317 \\ 27 & 640.67 & 14.0000 \\ 28 & 662.80 & 1.8106 \\ 29 & 696.58 & 11.7395 \\ 30 & 721.57 & 50.3388 \\ 31 & 747.57 & 21.3818 \\ 32 & 755.47 & 141.9088 \\ 33 & 760.97 & 3.7392 \\ 34 & 772.19 & 33.8321 \\ 35 & 781.58 & 21.9978 \\ 36 & 817.25 & 18.9918 \\ 37 & 819.37 & 0.5393 \\ 38 & 824.62 & 0.3504 \\ 39 & 869.44 & 73.8751 \\ 40 & 889.66 & 0.0336 \\ 41 & 897.31 & 4.3901 \\ 42 & 910.61 & 114.9783 \\ 43 & 932.74 & 0.0131 \\ 44 & 949.81 & 68.5243 \\ 46 & 965.53 & 10.4749 \\ & 968.68 & 0.1420\end{array}$




$\begin{array}{lll}47 & 1001.78 & 0.0507 \\ 48 & 1002.22 & 0.1818 \\ 49 & 1002.83 & 0.2668 \\ 50 & 1011.33 & 28.3777 \\ 51 & 1033.59 & 0.0073 \\ 52 & 1037.11 & 5.8809 \\ 53 & 1041.48 & 16.8810 \\ 54 & 1054.97 & 14.6834 \\ 55 & 1093.81 & 8.6219 \\ 56 & 1114.39 & 4.2985 \\ 57 & 1120.66 & 18.3324 \\ 58 & 1153.45 & 8.5208 \\ 59 & 1155.55 & 0.9837 \\ 60 & 1156.46 & 4.6054 \\ 61 & 1163.63 & 3.5635 \\ 62 & 1184.03 & 76.0830 \\ 63 & 1212.47 & 66.0232 \\ 64 & 1242.40 & 4.6349 \\ 65 & 1250.27 & 49.4021 \\ 66 & 1268.21 & 29.4547 \\ 67 & 1326.23 & 12.3164 \\ 68 & 1327.90 & 79.1700 \\ 69 & 1346.87 & 8.8714 \\ 70 & 1353.99 & 9.7075 \\ 71 & 1375.09 & 55.8018 \\ 72 & 1377.70 & 145.5146 \\ 73 & 1381.75 & 452.4409 \\ 74 & 1470.87 & 1.0469 \\ 75 & 1475.05 & 11.5773 \\ 76 & 1482.59 & 48.1489 \\ 77 & 1496.78 & 56.0519 \\ & 1500.01 & 51.3519\end{array}$




$\begin{array}{lll}79 & 1506.21 & 6.0001 \\ 80 & 1597.02 & 88.0443 \\ 81 & 1602.13 & 1.6039 \\ 82 & 1602.81 & 3.5402 \\ 83 & 1632.23 & 102.3711 \\ 84 & 1637.43 & 50.4129 \\ 85 & 1648.89 & 53.9513 \\ 86 & 1660.43 & 6.2888 \\ 87 & 1772.06 & 334.8651 \\ 88 & 3156.53 & 1.7807 \\ 89 & 3157.20 & 17.0680 \\ 90 & 3161.41 & 4.8938 \\ 91 & 3162.98 & 2.0444 \\ 92 & 3169.12 & 1.8713 \\ 93 & 3172.57 & 39.3022 \\ 94 & 3173.15 & 81.3357 \\ 95 & 3180.25 & 18.6324 \\ 96 & 3185.28 & 100.5773 \\ 97 & 3186.06 & 20.9267 \\ 98 & 3190.38 & 30.0401 \\ 99 & 3206.39 & 16.1973\end{array}$




\subsection{Internal Reaction Coordinate Calculation for Intramolecular Proton Transfer in $\operatorname{Flr}(\mathrm{H}) \mathrm{CO}_{2}^{-}$}

The following coordinates are the SVP optimized candidate transition state structure for intramolecular proton transfer in $\mathrm{F} \operatorname{lr}(\mathrm{H}) \mathrm{CO}_{2}{ }^{-}(\mathbf{S 5 . 2 5})$.

B3LYP/def2SVP irc $=$ calcfc, MaxPoints $=50$, StepSize $=10$

$\begin{array}{llll}-1 & 1 & & \\ \mathrm{C} & -1.53377700 & 3.47519700 & -0.31307300 \\ \mathrm{C} & -2.89309400 & 3.10506100 & -0.26511000 \\ \mathrm{C} & -3.25132400 & 1.75995000 & -0.14497600 \\ \mathrm{C} & -0.52259800 & 2.51487300 & -0.23127700 \\ \mathrm{C} & -2.24735500 & 0.78115400 & -0.07583300 \\ \mathrm{C} & -0.02507900 & -0.03642800 & 0.07082300 \\ \mathrm{C} & -0.96522000 & -1.16261600 & 0.04419200 \\ \mathrm{C} & -2.31034000 & -0.67021500 & 0.01935900 \\ \mathrm{C} & -3.39536000 & -1.55933300 & 0.07447400 \\ \mathrm{C} & -3.15479900 & -2.93460100 & 0.12820600 \\ \mathrm{C} & -0.74222400 & -2.55183800 & 0.09185600 \\ \mathrm{C} & -1.83271400 & -3.42383400 & 0.12994100 \\ \mathrm{H} & -1.26750500 & 4.53150300 & -0.41533100 \\ \mathrm{H} & -1.65925300 & -4.50363700 & 0.16300500 \\ \mathrm{H} & -3.66805900 & 3.87402800 & -0.32596900 \\ \mathrm{H} & -4.42259100 & -1.18181400 & 0.06582400 \\ \mathrm{H} & -3.99334500 & -3.63543300 & 0.16419500 \\ \mathrm{H} & -0.13079000 & -0.51719200\end{array}$




$\begin{array}{llll}\text { C } & 2.50462900 & 0.00305700 & 0.30206800 \\ \text { C } & 3.78797200 & -0.07306700 & -0.26505900 \\ \text { C } & 3.95518100 & -0.28632100 & -1.63227800 \\ \text { C } & 2.82676100 & -0.42819600 & -2.45078300 \\ \text { C } & 1.54822600 & -0.34985100 & -1.89524900 \\ \text { H } & 4.64828600 & 0.03586900 & 0.39807800 \\ \text { H } & 4.95866700 & -0.34438200 & -2.06213300 \\ \text { H } & 2.94548700 & -0.59782800 & -3.52466900 \\ \text { H } & 0.66944100 & -0.45805300 & -2.53688800 \\ \text { C } & 2.40456100 & 0.20653300 & 1.80659500 \\ \text { O } & 3.41924900 & 0.33160200 & 2.48749000 \\ \text { O } & 1.20163100 & 0.22823300 & 2.30539400 \\ \text { C } & -0.86513500 & 1.15544300 & -0.10622100 \\ \text { H } & 0.52774700 & 2.81955500 & -0.26537100 \\ \text { H } & 0.44491400 & 0.09011700 & 1.38833300\end{array}$




\subsection{TS for MS-CPET between $\mathrm{F} \operatorname{lr}(\mathrm{H}) \mathrm{CO}_{2}{ }^{-}$and $\mathrm{N}^{\bullet+}\left(\mathrm{Ar} \mathrm{Br}_{3}\right.$}

These keywords were used on the following set of coordinates for the computed transition state structure.

B3LYP/def2-SVP opt=(calcfc, ts, noeigentest $)$ freq=noraman

$\begin{array}{lrrr}\text { O } & 2 & & \\ \mathrm{C} & 1.0010190000 & -4.1657050000 & -2.3767970000 \\ \mathrm{C} & -8.4753490000 & -2.2114230000 & 1.9714000000 \\ \mathrm{C} & -2.3854280000 & 5.8662160000 & -1.3253170000 \\ \mathrm{C} & -3.2851980000 & -0.1580170000 & -0.5785560000 \\ \mathrm{C} & -1.6812170000 & -3.1766920000 & -2.0841260000 \\ \mathrm{C} & -0.3342810000 & -2.9137820000 & -1.8188540000 \\ \mathrm{C} & 0.0466060000 & -1.7476630000 & -1.1497460000 \\ \mathrm{C} & -0.9308390000 & -0.8412820000 & -0.7349300000 \\ \mathrm{C} & -2.6519920000 & -2.2585700000 & -1.6808130000 \\ \mathrm{C} & -6.8584110000 & -1.5694660000 & 1.1787020000 \\ \mathrm{C} & -5.6369310000 & -2.1527160000 & 1.5272670000 \\ \mathrm{C} & -6.9079350000 & -0.5220130000 & 0.2543960000 \\ \mathrm{H} & -5.7267040000 & -0.0631230000 & -0.3297110000 \\ \mathrm{H} & -4.4580340000 & -1.6772750000 & 0.9518540000 \\ \mathrm{H} & -2.2912660000 & -1.0829900000 & -0.9971370000 \\ \mathrm{H} & -1.09 \\ \mathrm{H} & -4.4848340000 & -0.6297390000 & 0.0126030000 \\ \mathrm{H} & -3.2495810000 & 3.5167740000 & 0.0863620000 \\ \mathrm{H} & -2.6626480000 & 3.9889720000 & -1.0909580000 \\ \mathrm{C} & -2.2780440000 & 3.1003940000 & -2.0989610000 \\ \mathrm{C} & -2.4926320000 & 1.7321640000 & -1.9294160000 \\ \mathrm{H} & -3.0753520000 & 1.2334520000 & -0.7494200000 \\ \mathrm{H} & -3.4452300000 & 2.1456950000 & 0.2564130000 \\ \mathrm{H} & -3.7020290000 & -2.4584640000 & -1.9018400000 \\ \mathrm{H} & -1.9757810000 & -4.0836760000 & -2.6147660000 \\ \mathrm{H} & -0.6128640000 & 0.0561530000 & -0.1998080000 \\ \mathrm{H} & -0.0730580000 & -0.0237180000\end{array}$




\begin{tabular}{|c|c|c|c|}
\hline $\mathrm{H}$ & -5.5983650000 & -2.9646940000 & 53990000 \\
\hline $\mathrm{H}$ & -3.5046390000 & -2.1248060000 & 1.2377670000 \\
\hline $\mathrm{C}$ & -5.7711760000 & 0.7434440000 & -1.0636020000 \\
\hline $\mathrm{O}$ & -3.5411620000 & 4.2103730000 & .8768170000 \\
\hline $\mathrm{O}$ & -1.8265120000 & 3.4703570000 & -3.0210170000 \\
\hline $\mathrm{C}$ & -2.2057580000 & 1.0433210000 & -2.7256940000 \\
\hline $\mathrm{H}$ & -3.8892720000 & 1.7804160000 & 1.1839680000 \\
\hline $\mathrm{H}$ & 6.7422870000 & 0.9249600000 & -2.5121710000 \\
\hline $\mathrm{Br}$ & 7.4088870000 & -0.3024150000 & -2.6384350000 \\
\hline $\mathrm{Br}$ & 7.3534370000 & -1.2683540000 & -1.6156790000 \\
\hline $\mathrm{Br}$ & 5.9979600000 & 1.2167660000 & -1.3629010000 \\
\hline $\mathrm{N}$ & 6.6201570000 & -0.9884980000 & -0.4676750000 \\
\hline $\mathrm{C}$ & 5.2251390000 & 0.2812900000 & 0.9377640000 \\
\hline $\mathrm{C}$ & 5.5688120000 & -0.9627630000 & 1.6255560000 \\
\hline $\mathrm{C}$ & 6.3874500000 & -1.7565960000 & 0.7658370000 \\
\hline $\mathrm{C}$ & 6.8257460000 & -3.0094880000 & 1.1809170000 \\
\hline $\mathrm{C}$ & 6.4476110000 & -3.4732570000 & 2.4552780000 \\
\hline $\mathrm{C}$ & 5.1948290000 & -1.4327020000 & 2.8929380000 \\
\hline $\mathrm{C}$ & 5.6452930000 & -2.6937690000 & 3.3010920000 \\
\hline $\mathrm{C}$ & 6.8036090000 & 1.6592080000 & -3.3185700000 \\
\hline $\mathrm{C}$ & 7.9832780000 & -0.5130660000 & -3.5436940000 \\
\hline $\mathrm{C}$ & 7.8859750000 & -2.2156760000 & -1.7280550000 \\
\hline $\mathrm{C}$ & 7.4581200000 & -3.6273060000 & 0.5389850000 \\
\hline $\mathrm{C}$ & 6.7876790000 & -4.4560610000 & 2.7903720000 \\
\hline $\mathrm{C}$ & 4.5651640000 & -0.8269880000 & 3.5487670000 \\
\hline $\mathrm{C}$ & 5.3684250000 & -3.0750170000 & 4.2865740000 \\
\hline $\mathrm{C}$ & 4.7275830000 & 1.5200390000 & 1.6168860000 \\
\hline $\mathrm{C}$ & 3.3671190000 & 1.8958050000 & 1.5762130000 \\
\hline $\mathrm{C}$ & 2.9441380000 & 3.0646290000 & 2.2265700000 \\
\hline $\mathrm{C}$ & 3.8558030000 & 3.8620100000 & 2.9158590000 \\
\hline $\mathrm{H}$ & 5.2051460000 & 3.4922330000 & 2.9597470000 \\
\hline $\mathrm{H}$ & 5.6377910000 & 2.3308910000 & 2.3158690000 \\
\hline
\end{tabular}




$\begin{array}{lrrr}\mathrm{H} & 1.8863610000 & 3.3284730000 & 2.1778110000 \\ \mathrm{H} & 3.5180600000 & 4.7704820000 & 3.4197170000 \\ \mathrm{H} & 5.9268390000 & 4.1111290000 & 3.4984520000 \\ \mathrm{H} & 6.6913460000 & 2.0452260000 & 2.3521980000 \\ \mathrm{H} & 2.3313700000 & 1.0729260000 & 0.8531770000 \\ \mathrm{H} & 1.1556020000 & 1.3939130000 & 0.8180100000 \\ \mathrm{H} & 2.7653600000 & -0.0249180000 & 0.2561960000 \\ \mathrm{H} & 5.9395390000 & 0.2603370000 & -0.3387230000 \\ \mathrm{H} & 5.4739490000 & 2.1704100000 & -1.2655840000 \\ \mathrm{H} & 4.2767870747 & -0.1786725343 & 0.4972571522\end{array}$

The following coordinates are the result of the transition state search and contain only a single imaginary frequency. This corresponds to the movement of the fluorenyl proton towards the carboxylate oxygen.

\begin{tabular}{lrrr} 
O & \multicolumn{1}{l}{} \\
$\mathrm{C}$ & 0.76368800 & -4.43650200 & -1.93935700 \\
$\mathrm{C}$ & -8.84627000 & -1.85718300 & 1.68226600 \\
$\mathrm{C}$ & -2.05142700 & 5.76820600 & -1.14630000 \\
$\mathrm{C}$ & -3.37591000 & -0.17051900 & -0.48713200 \\
$\mathrm{C}$ & -1.87609100 & -3.32399800 & -1.78610100 \\
$\mathrm{C}$ & -0.52576400 & -3.10804900 & -1.48392800 \\
$\mathrm{C}$ & -0.11237400 & -1.92936100 & -0.85434000 \\
$\mathrm{C}$ & -1.05585200 & -0.95965100 & -0.52258600 \\
$\mathrm{C}$ & -2.81606800 & -2.34900700 & -1.46123700 \\
$\mathrm{C}$ & -7.14374600 & -1.32917400 & 1.00918600 \\
$\mathrm{C}$ & -5.99021800 & -1.98154400 & 1.45834000 \\
$\mathrm{C}$ & -7.06048600 & -0.29443000 & 0.07081500 \\
$\mathrm{H}$ & -5.81451400 & 0.08501300 & -0.42457700 \\
$\mathrm{H}$ & -4.74574100 & -1.59302000 & 0.96654300 \\
$\mathrm{H}$ & -2.41812000 & -1.15595300 & -0.82398400 \\
$\mathrm{H}$ & -4.64267600 & -0.55831100 & 0.01738300 \\
$\mathrm{H}$ & -3.18367700 & 3.49100900 & 0.17976600 \\
$\mathrm{H}$ & -2.46265500 & 3.91946400 & -0.94051000
\end{tabular}




\begin{tabular}{|c|c|c|c|}
\hline $\mathrm{H}$ & -2.04056800 & 3.00408300 & -1.91128100 \\
\hline $\mathrm{C}$ & -2.34683700 & 1.65348000 & -1.76201200 \\
\hline $\mathrm{C}$ & -3.06810300 & 1.20201200 & -0.63902000 \\
\hline $\mathrm{C}$ & -3.47967500 & 2.13811800 & 0.33020300 \\
\hline $\mathrm{C}$ & -3.86476500 & -2.50807800 & -1.71678700 \\
\hline $\mathrm{C}$ & -2.19202400 & -4.23929700 & -2.28896100 \\
\hline $\mathrm{C}$ & 0.93443300 & -1.74991300 & -0.59734800 \\
\hline $\mathrm{H}$ & -0.70712800 & -0.05694900 & -0.01505700 \\
\hline $\mathrm{H}$ & -7.96302800 & 0.20514800 & -0.28450500 \\
\hline $\mathrm{H}$ & -6.05818400 & -2.77959800 & 2.19918300 \\
\hline $\mathrm{H}$ & -3.84470400 & -2.08875500 & 1.33087200 \\
\hline $\mathrm{C}$ & -5.75154100 & 0.87868900 & -1.17061100 \\
\hline $\mathrm{O}$ & -3.50092300 & 4.20567300 & 0.94060200 \\
\hline $\mathrm{O}$ & -1.48786300 & 3.34332000 & -2.78863200 \\
\hline $\mathrm{C}$ & -2.03559200 & 0.94397800 & -2.52995000 \\
\hline $\mathrm{H}$ & -4.02427200 & 1.80304600 & 1.21408800 \\
\hline $\mathrm{H}$ & 6.66828000 & 0.42185500 & -2.83889000 \\
\hline $\mathrm{Br}$ & 7.62817000 & -0.59194800 & -2.70670000 \\
\hline $\mathrm{Br}$ & 7.75615500 & -1.30851700 & -1.50654800 \\
\hline $\mathrm{Br}$ & 5.81125500 & 0.73507800 & -1.77528600 \\
\hline $\mathrm{N}$ & 6.90897200 & -0.99713300 & -0.44138500 \\
\hline $\mathrm{C}$ & 5.12250700 & 0.12154100 & 0.67618900 \\
\hline $\mathrm{C}$ & 5.78667600 & -0.84270100 & 1.60682200 \\
\hline $\mathrm{C}$ & 6.81678400 & -1.53972300 & 0.92228000 \\
\hline $\mathrm{C}$ & 7.54782600 & -2.53434600 & 1.57457700 \\
\hline $\mathrm{C}$ & 7.24944800 & -2.82688700 & 2.91454700 \\
\hline $\mathrm{C}$ & 5.49423200 & -1.13948000 & 2.94126700 \\
\hline $\mathrm{C}$ & 6.23598300 & -2.13412600 & 3.59254300 \\
\hline $\mathrm{C}$ & 6.58696300 & 0.97098000 & -3.78011000 \\
\hline $\mathrm{C}$ & 8.28721300 & -0.82514500 & -3.54667700 \\
\hline $\mathrm{C}$ & 8.51363200 & -2.09066600 & -1.41202300 \\
\hline $\mathrm{C}$ & 8.34565000 & -3.07489600 & 1.05910500 \\
\hline
\end{tabular}




$\begin{array}{llll}\mathrm{C} & 7.81668200 & -3.60176900 & 3.43620700 \\ \mathrm{C} & 4.70055000 & -0.60531000 & 3.46973400 \\ \mathrm{C} & 6.02164700 & -2.37377500 & 4.63689000 \\ \mathrm{C} & 4.68202500 & 1.47636700 & 1.18486300 \\ \mathrm{C} & 3.31505700 & 1.82046900 & 1.20904300 \\ \mathrm{C} & 2.92211900 & 3.08291700 & 1.68324500 \\ \mathrm{C} & 3.86989700 & 4.00157200 & 2.13082700 \\ \mathrm{H} & 5.22862100 & 3.66198400 & 2.10696100 \\ \mathrm{H} & 5.62906300 & 2.40985100 & 1.63770300 \\ \mathrm{H} & 1.85715700 & 3.32152400 & 1.69052400 \\ \mathrm{H} & 3.55409100 & 4.98106300 & 2.49816700 \\ \mathrm{H} & 5.97919400 & 4.37616500 & 2.45540400 \\ \mathrm{H} & 6.68987300 & 2.14716000 & 1.61991900 \\ \mathrm{H} & 2.22653100 & 0.87415900 & 0.73702200 \\ \mathrm{H} & 1.04291500 & 1.22410700 & 0.76811500 \\ \mathrm{H} & 2.58882400 & -0.29147100 & 0.30811500 \\ \mathrm{H} & 5.93414200 & 0.02581700 & -0.57706800 \\ \mathrm{H} & 5.05987600 & 1.52148800 & -1.88274700 \\ \mathrm{H} & 4.04736100 & -0.34434100 & 0.41342300\end{array}$

$\begin{array}{lll}\# & \text { frequency } & v\left(\mathrm{~cm}^{-1}\right) \\ 1 & -1867.07 & 3612744.5961 \\ 2 & 4.66 & 0.1941 \\ 3 & 6.94 & 0.1116 \\ 4 & 7.90 & 0.0422 \\ 5 & 12.21 & 0.4919 \\ 6 & 16.29 & 2.5736 \\ 7 & 24.10 & 2.9588 \\ 8 & 24.65 & 0.4246 \\ 9 & 28.23 & 1.5629 \\ 10 & 29.58 & 2.4182 \\ 11 & 39.17 & 0.3672\end{array}$




\begin{tabular}{|c|c|c|}
\hline 12 & 45.12 & 5.2787 \\
\hline 12 & 55.43 & 0.3435 \\
\hline 14 & 60.06 & 70.7936 \\
\hline & 62.47 & 87.4108 \\
\hline 16 & 95.63 & 2.3278 \\
\hline 17 & 100.91 & 32.1856 \\
\hline 18 & 102.13 & 0.3473 \\
\hline 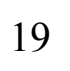 & 118.21 & 0.1352 \\
\hline 20 & 121.65 & 0.0105 \\
\hline 21 & 121.82 & 0.1869 \\
\hline 22 & 135.41 & 1.5398 \\
\hline & 142.56 & 0.2496 \\
\hline & 152.45 & 80.7269 \\
\hline 25 & 174.21 & 238.9038 \\
\hline 26 & 192.20 & 3.5876 \\
\hline 27 & 196.29 & 2.9100 \\
\hline 28 & 224.10 & 0.8844 \\
\hline 29 & 247.39 & 2.0838 \\
\hline 30 & 252.15 & 307.1085 \\
\hline 31 & 278.32 & 10.5237 \\
\hline 32 & 279.48 & 7.1499 \\
\hline 33 & 290.58 & 3149.3500 \\
\hline 3 & 294.68 & 18.8931 \\
\hline 35 & 310.63 & 3.1366 \\
\hline$x$ & 331.92 & 15.6307 \\
\hline$J$ & 333.42 & 4.7647 \\
\hline 38 & 345.43 & 1494.6421 \\
\hline 39 & 408.71 & 8.4308 \\
\hline 40 & 412.00 & 19.3567 \\
\hline 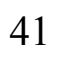 & 423.06 & 0.4832 \\
\hline 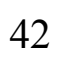 & 423.60 & 154.4736 \\
\hline 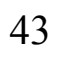 & 425.51 & 4.2460 \\
\hline
\end{tabular}




\begin{tabular}{|c|c|c|}
\hline 44 & 431.38 & 201.4990 \\
\hline 15 & 433.73 & 8.9051 \\
\hline 46 & 441.59 & 0.5613 \\
\hline 47 & 446.40 & 33.7452 \\
\hline 48 & 464.56 & 3.4412 \\
\hline 49 & 481.76 & 856.4045 \\
\hline 50 & 483.67 & 10.7432 \\
\hline 51 & 502.49 & 0.5602 \\
\hline 52 & 514.02 & 10351.8914 \\
\hline 53 & 516.77 & 43.0027 \\
\hline 54 & 531.45 & 28.9629 \\
\hline 55 & 536.87 & 32.0542 \\
\hline 56 & 560.46 & 132.4709 \\
\hline 57 & 563.47 & 9713.1263 \\
\hline 58 & 581.97 & 1.1228 \\
\hline 59 & 622.66 & 10.4563 \\
\hline 60 & 628.74 & 16.3605 \\
\hline 61 & 632.86 & 1000.4877 \\
\hline 62 & 634.20 & 1053.2397 \\
\hline 63 & 635.42 & 11466.2808 \\
\hline 64 & 638.66 & 771.9595 \\
\hline 65 & 643.19 & 18.7666 \\
\hline 66 & 683.28 & 211.0224 \\
\hline 67 & 684.36 & 240.4193 \\
\hline 68 & 685.96 & 4912.7262 \\
\hline 69 & 715.41 & 46.0700 \\
\hline 70 & 736.96 & 9.0600 \\
\hline 71 & 740.64 & 5708.5024 \\
\hline 72 & 741.42 & 53.7587 \\
\hline 73 & 744.03 & 82.6161 \\
\hline 74 & 758.51 & 148.1792 \\
\hline 75 & 762.18 & 374.0206 \\
\hline
\end{tabular}




\begin{tabular}{|c|c|c|}
\hline 76 & 767.90 & 177.3343 \\
\hline 7 & 769.90 & 5693.1208 \\
\hline & 777.79 & 84.4370 \\
\hline & 788.70 & 1281.3737 \\
\hline & 813.29 & 15.2348 \\
\hline & 815.77 & 3.2893 \\
\hline & 836.45 & 5.4217 \\
\hline & 838.49 & 104.4646 \\
\hline & 843.51 & 90.6240 \\
\hline & 851.71 & 22.8495 \\
\hline & 853.81 & 1326.8421 \\
\hline 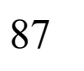 & 854.91 & 47.0635 \\
\hline 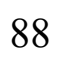 & 884.86 & 15.6877 \\
\hline 80 & 897.30 & 42.7495 \\
\hline 90 & 905.44 & 11.1445 \\
\hline 91 & 910.95 & 0.4411 \\
\hline 92 & 929.35 & 1.3465 \\
\hline 03 & 938.54 & 189.7645 \\
\hline 94 & 939.73 & 27.2524 \\
\hline 95 & 942.73 & 6055.3051 \\
\hline 96 & 981.50 & 71.9066 \\
\hline 97 & 983.96 & 10.0745 \\
\hline 0 & 989.44 & 0.5163 \\
\hline 99 & 990.66 & 1.5504 \\
\hline 100 & 992.76 & 0.0823 \\
\hline 101 & 999.88 & 0.0583 \\
\hline 102 & 1000.23 & 0.5093 \\
\hline 103 & 1003.29 & 0.7527 \\
\hline 104 & 1006.82 & 92.2428 \\
\hline 105 & 1013.33 & 67.1899 \\
\hline 106 & 1014.23 & 92.8587 \\
\hline 107 & 1017.56 & 0.4079 \\
\hline
\end{tabular}




$\begin{array}{lll}108 & 1022.48 & 0.1958 \\ 109 & 1023.61 & 1.0653 \\ 110 & 1036.98 & 0.0486 \\ 111 & 1041.40 & 0.3004 \\ 112 & 1045.97 & 11.1391 \\ 113 & 1048.15 & 9.5370 \\ 114 & 1056.47 & 46.9866 \\ 115 & 1081.42 & 1422.0825 \\ 116 & 1085.12 & 268.5657 \\ 117 & 1085.77 & 143.5860 \\ 118 & 1093.81 & 691.9782 \\ 119 & 1104.88 & 77.6222 \\ 120 & 1112.67 & 1035.6087 \\ 121 & 1126.44 & 14.4387 \\ 122 & 1129.38 & 8.4692 \\ 123 & 1137.06 & 32.4514 \\ 124 & 1143.60 & 79.0797 \\ 125 & 1157.81 & 1230.5188 \\ 126 & 1161.40 & 218.2018 \\ 127 & 1164.09 & 5.8418 \\ 128 & 1165.72 & 57.1593 \\ 129 & 1177.32 & 3134.4622 \\ 130 & 1182.67 & 25.9271 \\ 131 & 1184.55 & 20.3960 \\ 132 & 1188.64 & 391.9474 \\ 133 & 1213.11 & 547.3952 \\ 134 & 1216.75 & 2.0673 \\ 135 & 1235.02 & 2780.9632 \\ 136 & 1255.51 & 6263.4545 \\ 137 & 1288.62 & 17269.4694 \\ 138 & 1298.77 & 12.1222 \\ 139 & 1301.26 & 66.9942 \\ & & \end{array}$




$\begin{array}{lll}140 & 1304.32 & 3.3923 \\ 141 & 1305.76 & 40.7727 \\ 142 & 1310.98 & 6959.4168 \\ 143 & 1317.35 & 141.9372 \\ 144 & 1317.80 & 810.9849 \\ 145 & 1319.71 & 1051.3335 \\ 146 & 1323.81 & 34.2864 \\ 147 & 1345.07 & 13.2279 \\ 148 & 1354.89 & 473.9219 \\ 149 & 1357.26 & 11.9527 \\ 150 & 1359.12 & 8.4558 \\ 151 & 1395.11 & 1706.5395 \\ 152 & 1431.14 & 167.3797 \\ 153 & 1444.22 & 275.6290 \\ 154 & 1445.89 & 167.8572 \\ 155 & 1464.98 & 1472.2078 \\ 156 & 1467.53 & 31.9872 \\ 157 & 1474.01 & 652.7066 \\ 158 & 1493.31 & 6.9250 \\ 159 & 1501.20 & 6899.4525 \\ 160 & 1504.98 & 311.1550 \\ 161 & 1506.16 & 441.0214 \\ 162 & 1510.63 & 586.3264 \\ 163 & 1511.58 & 85.3678 \\ 164 & 1549.71 & 65930.2598 \\ 165 & 1597.32 & 3.6986 \\ 166 & 1608.25 & 24.1218 \\ 167 & 1610.25 & 30.1367 \\ 168 & 1615.54 & 0.5918 \\ 169 & 1618.46 & 142.3802 \\ 170 & 1620.29 & 167.0442 \\ 171 & 1623.00 & 222.6532 \\ & & \\ 145\end{array}$




$\begin{array}{lll}172 & 1623.33 & 184.4896 \\ 173 & 1632.71 & 152.2677 \\ 174 & 1641.94 & 992.6857 \\ 175 & 1646.39 & 224.7995 \\ 176 & 1657.14 & 1026.6069 \\ 177 & 1722.42 & 31173.5312 \\ 178 & 3178.16 & 12.5301 \\ 179 & 3178.57 & 290.8165 \\ 180 & 3178.70 & 108.0508 \\ 181 & 3183.78 & 4.1729 \\ 182 & 3184.64 & 780.4047 \\ 183 & 3187.76 & 253.4603 \\ 184 & 3188.50 & 136.6492 \\ 185 & 3190.77 & 4285.2542 \\ 186 & 3191.95 & 3.0482 \\ 187 & 3192.50 & 39.8912 \\ 188 & 3198.29 & 690.3197 \\ 189 & 3201.30 & 2224.1836 \\ 190 & 3201.62 & 468.3245 \\ 191 & 3205.77 & 17.6692 \\ 192 & 3205.93 & 3.6347 \\ 193 & 3207.23 & 22.3774 \\ 194 & 3207.60 & 0.2368 \\ 195 & 3208.92 & 1.5609 \\ 196 & 3211.44 & 130.3839 \\ 197 & 3217.78 & 628.2728 \\ 198 & 3217.93 & 69.0758 \\ 199 & 3218.92 & 686.9926 \\ 200 & 3219.26 & 1.0609 \\ 201 & 3220.12 & 499.6142\end{array}$




\subsection{Internal Reaction Coordinate Calculation for MS-CPET between $\mathrm{Flr}(\mathrm{H}) \mathrm{CO}_{2}^{-}$and $\mathbf{N}^{\cdot+}\left(\mathbf{A r}_{\mathbf{B r}}\right)_{3}$}

The following coordinates are the SVP optimized candidate transition state structure for MS-CPET between $\mathrm{F} \operatorname{lr}(\mathrm{H}) \mathrm{CO} 2^{-}$and $\mathrm{N}^{\bullet+}\left(\mathrm{Ar}_{\mathrm{Br}}\right)_{3}(\mathbf{S 5 . 2 7})$.

B3LYP/def2SVP irc $=$ calcfc, MaxPoints $=100$, StepSize $=5$

\begin{tabular}{|c|c|c|c|}
\hline 0 & 2 & & \\
\hline $\mathrm{C}$ & 0.76368800 & -4.43650200 & -1.93935700 \\
\hline $\mathrm{C}$ & -8.84627000 & -1.85718300 & 1.68226600 \\
\hline $\mathrm{C}$ & -2.05142700 & 5.76820600 & -1.14630000 \\
\hline $\mathrm{C}$ & -3.37591000 & -0.17051900 & -0.48713200 \\
\hline $\mathrm{C}$ & -1.87609100 & -3.32399800 & -1.78610100 \\
\hline $\mathrm{C}$ & -0.52576400 & -3.10804900 & -1.48392800 \\
\hline $\mathrm{C}$ & -0.11237400 & -1.92936100 & -0.85434000 \\
\hline $\mathrm{C}$ & -1.05585200 & -0.95965100 & -0.52258600 \\
\hline $\mathrm{C}$ & -2.81606800 & -2.34900700 & -1.46123700 \\
\hline $\mathrm{C}$ & -7.14374600 & -1.32917400 & 1.00918600 \\
\hline $\mathrm{C}$ & -5.99021800 & -1.98154400 & 1.45834000 \\
\hline $\mathrm{C}$ & -7.06048600 & -0.29443000 & 0.07081500 \\
\hline $\mathrm{H}$ & -5.81451400 & 0.08501300 & -0.42457700 \\
\hline $\mathrm{H}$ & -4.74574100 & -1.59302000 & 0.96654300 \\
\hline $\mathrm{H}$ & -2.41812000 & -1.15595300 & -0.82398400 \\
\hline $\mathrm{H}$ & -4.64267600 & -0.55831100 & 0.01738300 \\
\hline $\mathrm{H}$ & -3.18367700 & 3.49100900 & 0.17976600 \\
\hline $\mathrm{H}$ & -2.46265500 & 3.91946400 & -0.94051000 \\
\hline $\mathrm{H}$ & -2.04056800 & 3.00408300 & -1.91128100 \\
\hline $\mathrm{C}$ & -2.34683700 & 1.65348000 & -1.76201200 \\
\hline $\mathrm{C}$ & -3.06810300 & 1.20201200 & -0.63902000 \\
\hline $\mathrm{C}$ & -3.47967500 & 2.13811800 & 0.33020300 \\
\hline $\mathrm{C}$ & -3.86476500 & -2.50807800 & -1.71678700 \\
\hline $\mathrm{C}$ & -2.19202400 & -4.23929700 & -2.28896100 \\
\hline $\mathrm{C}$ & 0.93443300 & -1.74991300 & -0.59734800 \\
\hline $\mathrm{H}$ & -0.70712800 & -0.05694900 & -0.01505700 \\
\hline $\mathrm{H}$ & -7.96302800 & 0.20514800 & -0.28450500 \\
\hline
\end{tabular}




\begin{tabular}{|c|c|c|c|}
\hline $\mathrm{H}$ & -6.05818400 & -2.77959800 & 2.19918300 \\
\hline $\mathrm{H}$ & -3.84470400 & -2.08875500 & 1.33087200 \\
\hline $\mathrm{C}$ & -5.75154100 & 0.87868900 & -1.17061100 \\
\hline $\mathrm{O}$ & -3.50092300 & 4.20567300 & 0.94060200 \\
\hline $\mathrm{O}$ & -1.48786300 & 3.34332000 & -2.78863200 \\
\hline $\mathrm{C}$ & -2.03559200 & 0.94397800 & -2.52995000 \\
\hline $\mathrm{H}$ & -4.02427200 & 1.80304600 & 1.21408800 \\
\hline $\mathrm{H}$ & 6.66828000 & 0.42185500 & -2.83889000 \\
\hline $\mathrm{Br}$ & 7.62817000 & -0.59194800 & -2.70670000 \\
\hline $\mathrm{Br}$ & 7.75615500 & -1.30851700 & -1.50654800 \\
\hline $\mathrm{Br}$ & 5.81125500 & 0.73507800 & -1.77528600 \\
\hline $\mathrm{N}$ & 6.90897200 & -0.99713300 & -0.44138500 \\
\hline $\mathrm{C}$ & 5.12250700 & 0.12154100 & 0.67618900 \\
\hline $\mathrm{C}$ & 5.78667600 & -0.84270100 & 1.60682200 \\
\hline $\mathrm{C}$ & 6.81678400 & -1.53972300 & 0.92228000 \\
\hline $\mathrm{C}$ & 7.54782600 & -2.53434600 & 1.57457700 \\
\hline $\mathrm{C}$ & 7.24944800 & -2.82688700 & 2.91454700 \\
\hline $\mathrm{C}$ & 5.49423200 & -1.13948000 & 2.94126700 \\
\hline $\mathrm{C}$ & 6.23598300 & -2.13412600 & 3.59254300 \\
\hline $\mathrm{C}$ & 6.58696300 & 0.97098000 & -3.78011000 \\
\hline $\mathrm{C}$ & 8.28721300 & -0.82514500 & -3.54667700 \\
\hline $\mathrm{C}$ & 8.51363200 & -2.09066600 & -1.41202300 \\
\hline $\mathrm{C}$ & 8.34565000 & -3.07489600 & 1.05910500 \\
\hline $\mathrm{C}$ & 7.81668200 & -3.60176900 & 3.43620700 \\
\hline $\mathrm{C}$ & 4.70055000 & -0.60531000 & 3.46973400 \\
\hline $\mathrm{C}$ & 6.02164700 & -2.37377500 & 4.63689000 \\
\hline $\mathrm{C}$ & 4.68202500 & 1.47636700 & 1.18486300 \\
\hline $\mathrm{C}$ & 3.31505700 & 1.82046900 & 1.20904300 \\
\hline $\mathrm{C}$ & 2.92211900 & 3.08291700 & 1.68324500 \\
\hline $\mathrm{C}$ & 3.86989700 & 4.00157200 & 2.13082700 \\
\hline $\mathrm{H}$ & 5.22862100 & 3.66198400 & 2.10696100 \\
\hline $\mathrm{H}$ & 5.62906300 & 2.40985100 & 1.63770300 \\
\hline
\end{tabular}




$\begin{array}{lrrr}\mathrm{H} & 1.85715700 & 3.32152400 & 1.69052400 \\ \mathrm{H} & 3.55409100 & 4.98106300 & 2.49816700 \\ \mathrm{H} & 5.97919400 & 4.37616500 & 2.45540400 \\ \mathrm{H} & 6.68987300 & 2.14716000 & 1.61991900 \\ \mathrm{H} & 2.22653100 & 0.87415900 & 0.73702200 \\ \mathrm{H} & 1.04291500 & 1.22410700 & 0.76811500 \\ \mathrm{H} & 2.58882400 & -0.29147100 & 0.30811500 \\ \mathrm{H} & 5.93414200 & 0.02581700 & -0.57706800 \\ \mathrm{H} & 5.05987600 & 1.52148800 & -1.88274700 \\ \mathrm{H} & 4.04736100 & -0.34434100 & 0.41342300\end{array}$




\subsection{TS for MS-CPET between $\mathrm{F} \operatorname{lr}(\mathrm{H}) \mathrm{CO}_{2}^{-}$and $\mathrm{N}^{\bullet+}(\mathrm{Ph})_{3}$}

These keywords were used on the following set of coordinates which correpond to an estimate for the transition state of MS-CPET between $\mathrm{Flr}(\mathrm{H}) \mathrm{CO}_{2}{ }^{-}$and $\mathrm{N}^{\cdot+}(\mathrm{Ph})_{3}$.

B3LYP/def2-SVP opt=(calcfc, ts, noeigentest $)$ freq=noraman

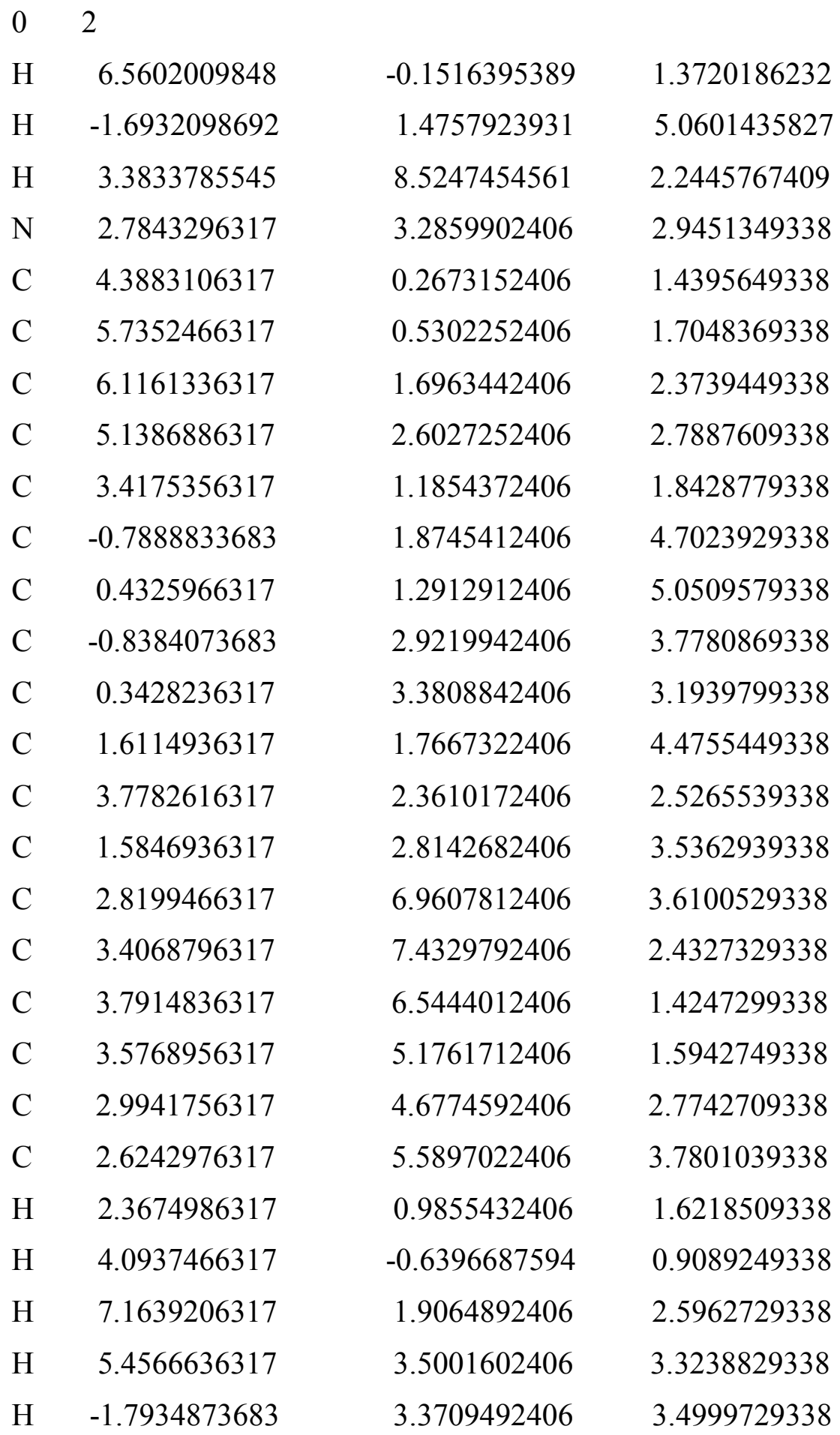




\begin{tabular}{|c|c|c|c|}
\hline I & 0.4711626317 & 0.4793132406 & 5.7790899338 \\
\hline $\mathrm{H}$ & 2.5648886317 & 1.3192012406 & 4.7614579338 \\
\hline 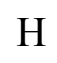 & 0.2983516317 & 4.1874512406 & 2.4600889338 \\
\hline $\mathrm{H}$ & 2.5283656317 & 7.6543802406 & 4.4005079338 \\
\hline $\mathrm{H}$ & 4.2430156317 & 6.9143642406 & 0.5026739338 \\
\hline $\mathrm{H}$ & 3.8637696317 & 4.4873282406 & 0.7979969338 \\
\hline $\mathrm{H}$ & 2.1802556317 & 5.2244232406 & 4.7076589338 \\
\hline$C$ & 12.8118146317 & 4.3689672406 & 1.0115199338 \\
\hline$C$ & 13.4784146317 & 3.1415922406 & 0.8852559338 \\
\hline $\mathrm{C}$ & 13.4229646317 & 2.1756532406 & 1.9080119338 \\
\hline $\mathrm{C}$ & 12.0674876317 & 4.6607732406 & 2.1607899338 \\
\hline $\mathrm{C}$ & 12.6896846317 & 2.4555092406 & 3.0560159338 \\
\hline $\mathrm{C}$ & 11.2946666317 & 3.7252972406 & 4.4614549338 \\
\hline $\mathrm{C}$ & 11.6383396317 & 2.4812442406 & 5.1492469338 \\
\hline $\mathrm{C}$ & 12.4569776317 & 1.6874112406 & 4.2895279338 \\
\hline $\mathrm{C}$ & 12.8952736317 & 0.4345192406 & 4.7046079338 \\
\hline $\mathrm{C}$ & 12.5171386317 & -0.0292497594 & 5.9789689338 \\
\hline $\mathrm{C}$ & 11.2643566317 & 2.0113052406 & 6.4166289338 \\
\hline $\mathrm{C}$ & 11.7148206317 & 0.7502382406 & 6.8247829338 \\
\hline $\mathrm{H}$ & 12.8731366317 & 5.1032152406 & 0.2051209338 \\
\hline $\mathrm{H}$ & 14.0528056317 & 2.9309412406 & -0.0200030662 \\
\hline $\mathrm{H}$ & 13.9555026317 & 1.2283312406 & 1.7956359338 \\
\hline $\mathrm{H}$ & 13.5276476317 & -0.1832987594 & 4.0626759338 \\
\hline $\mathrm{H}$ & 12.8572066317 & -1.0120537594 & 6.3140629338 \\
\hline $\mathrm{H}$ & 10.6346916317 & 2.6170192406 & 7.0724579338 \\
\hline $\mathrm{H}$ & 11.4379526317 & 0.3689902406 & 7.8102649338 \\
\hline $\mathrm{C}$ & 10.7971106317 & 4.9640462406 & 5.1405769338 \\
\hline $\mathrm{C}$ & 9.4366466317 & 5.3398122406 & 5.0999039338 \\
\hline $\mathrm{C}$ & 9.0136656317 & 6.5086362406 & 5.7502609338 \\
\hline $\mathrm{C}$ & 9.9253306317 & 7.3060172406 & 6.4395499338 \\
\hline $\mathrm{C}$ & 11.2746736317 & 6.9362402406 & 6.4834379338 \\
\hline$r$ & 11.7073186317 & 5.7748982406 & 5.8395599338 \\
\hline
\end{tabular}




$\begin{array}{cccc}\mathrm{H} & 7.9558886317 & 6.7724802406 & 5.7015019338 \\ \mathrm{H} & 9.5875876317 & 8.2144892406 & 6.9434079338 \\ \mathrm{H} & 11.9963666317 & 7.5551362406 & 7.0221429338 \\ \mathrm{H} & 12.7608736317 & 5.4892332406 & 5.8758889338 \\ \mathrm{C} & 8.4008976317 & 4.5169332406 & 4.3768679338 \\ \mathrm{O} & 7.2251296317 & 4.8379202406 & 4.3417009338 \\ \mathrm{O} & 8.8348876317 & 3.4190892406 & 3.7798869338 \\ \mathrm{C} & 12.0090666317 & 3.7043442406 & 3.1849679338 \\ \mathrm{H} & 11.5434766317 & 5.6144172406 & 2.2581069338 \\ \mathrm{H} & 10.3463147064 & 3.2653347063 & 4.0209480860\end{array}$

The following coordinates are the result of the transition state search and contain only a single imaginary frequency. This corresponds to movement of the proton between the fluorenyl carbon and the carboxylate oxygen.

$\begin{array}{llll}\text { O } & 2 & & \\ \mathrm{H} & 1.18720400 & -4.16119600 & 1.58669400 \\ \mathrm{H} & 9.19078900 & -1.52214700 & -2.13690800 \\ \mathrm{H} & 3.51047500 & 4.76610500 & 1.45176400 \\ \mathrm{~N} & 4.62755200 & -0.30959700 & 0.31553200 \\ \mathrm{C} & 3.27136100 & -3.58028500 & 1.46762600 \\ \mathrm{C} & 1.89307300 & -3.37007600 & 1.32297700 \\ \mathrm{C} & 1.42903700 & -2.13956100 & 0.84143900 \\ \mathrm{C} & 2.32543800 & -1.12630900 & 0.50483400 \\ \mathrm{C} & 4.17843500 & -2.57370200 & 1.14182900 \\ \mathrm{C} & 8.25394200 & -1.27341700 & -1.63329900 \\ \mathrm{C} & 7.06167200 & -1.90246600 & -2.01217300 \\ \mathrm{C} & 8.23769100 & -0.32328800 & -0.60465500 \\ \mathrm{C} & 7.04542400 & -0.00376100 & 0.04391200 \\ \mathrm{C} & 5.86222000 & -1.58658800 & -1.37499500 \\ \mathrm{C} & 3.71192300 & -1.33437400 & 0.65474900 \\ \mathrm{C} & 5.84397900 & -0.63315400 & -0.33782900 \\ \mathrm{C} & 4.34887100 & 3.39116300 & 0.00212900 \\ \mathrm{C} & 3.73874400 & 3.72381200 & 1.21802000\end{array}$




\begin{tabular}{|c|c|c|c|}
\hline C & 3.42297800 & 2.71074400 & 2.13193200 \\
\hline $\mathrm{C}$ & 3.71568800 & 1.37923100 & 1.84128300 \\
\hline & 4.32758500 & 1.04079800 & 0.61698900 \\
\hline $\mathrm{C}$ & 4.63998400 & 2.06247400 & -0.30312200 \\
\hline & 5.24908100 & -2.73464900 & 1.27761900 \\
\hline $\mathrm{H}$ & 3.64323600 & -4.53246800 & 1.85380700 \\
\hline & 0.36076800 & -1.94929300 & 0.70558900 \\
\hline & 1.93450800 & -0.18412000 & 0.11350600 \\
\hline U & 9.16461500 & 0.16524500 & -0.29491000 \\
\hline $\mathrm{H}$ & 7.06233400 & -2.63723500 & -2.82081100 \\
\hline & 4.93174200 & -2.06418400 & -1.68591100 \\
\hline & 7.03996500 & 0.72277400 & 0.85805400 \\
\hline $\mathrm{H}$ & 4.58893900 & 4.17275600 & -0.72260600 \\
\hline$H$ & 2.95611200 & 2.96074400 & 3.08759600 \\
\hline 1 & 3.48664000 & 0.59630200 & 2.56566600 \\
\hline $\mathrm{H}$ & 5.09707100 & 1.80734100 & -1.26040900 \\
\hline$C$ & -5.30805000 & 0.41711900 & 3.36138100 \\
\hline $\mathrm{C}$ & -6.24486200 & -0.62388500 & 3.27722000 \\
\hline 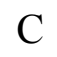 & -6.40971600 & -1.34608400 & 2.08553300 \\
\hline $\mathrm{C}$ & -4.51163500 & 0.75138800 & 2.25835900 \\
\hline$C$ & -5.62416300 & -1.01373600 & 0.97964300 \\
\hline$C$ & -3.92436100 & 0.14631500 & -0.21972500 \\
\hline$C$ & -4.60514600 & -0.82911900 & -1.11827800 \\
\hline . & -5.58340100 & -1.55471100 & -0.38581300 \\
\hline$C$ & -6.31751400 & -2.56949900 & -1.00368900 \\
\hline 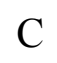 & -6.07734800 & -2.85400900 & -2.35656200 \\
\hline$C$ & -4.37075200 & -1.11958300 & -2.46654000 \\
\hline$C$ & -5.11630000 & -2.13358100 & -3.08171800 \\
\hline & -5.19750700 & 0.97105000 & 4.29692700 \\
\hline 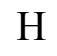 & -6.85604900 & -0.87305000 & 4.14828700 \\
\hline & -7.14843400 & -2.14964200 & 2.02825500 \\
\hline & -7.07422600 & -3.13157200 & -0.450361 \\
\hline
\end{tabular}




$\begin{array}{lrrr}\mathrm{H} & -6.64819700 & -3.64370900 & -2.85145100 \\ \mathrm{H} & -3.61848300 & -0.56444100 & -3.03277400 \\ \mathrm{H} & -4.94675100 & -2.36726800 & -4.13572900 \\ \mathrm{C} & -3.49540600 & 1.49784600 & -0.74190500 \\ \mathrm{C} & -2.12660400 & 1.82798800 & -0.82148500 \\ \mathrm{C} & -1.73998400 & 3.08747000 & -1.30772900 \\ \mathrm{C} & -2.69548300 & 4.01761600 & -1.71374300 \\ \mathrm{C} & -4.05580000 & 3.69257500 & -1.63534500 \\ \mathrm{C} & -4.45013300 & 2.44316700 & -1.15332600 \\ \mathrm{H} & -0.67357100 & 3.31432300 & -1.35781200 \\ \mathrm{H} & -2.38461200 & 4.99498500 & -2.09104000 \\ \mathrm{H} & -4.81211800 & 4.41593700 & -1.95106900 \\ \mathrm{H} & -5.51204100 & 2.19124000 & -1.09301300 \\ \mathrm{C} & -1.03322900 & 0.86203800 & -0.39764900 \\ \mathrm{O} & 0.15164600 & 1.19510400 & -0.48039100 \\ \mathrm{O} & -1.40544800 & -0.29796100 & 0.04211500 \\ \mathrm{C} & -4.67028500 & 0.03629800 & 1.06650600 \\ \mathrm{H} & -3.77866100 & 1.55905000 & 2.32976700 \\ \mathrm{H} & -2.80250700 & -0.31397300 & -0.00194600\end{array}$

\# frequency $\quad v\left(\mathrm{~cm}^{-1}\right)$

$1 \quad-2356.09 \quad 5508486.9160$

$\begin{array}{lll}2 & 6.33 & 0.8777\end{array}$

$3 \quad 9.20 \quad 0.1632$

$4 \quad 12.13 \quad 0.5478$

$5 \quad 16.81 \quad 0.0482$

$\begin{array}{lll}6 & 18.36 & 2.4384\end{array}$

$7 \quad 27.75 \quad 6.4325$

$\begin{array}{lll}8 & 35.53 & 0.9431\end{array}$ 


\begin{tabular}{|c|c|c|}
\hline 9 & 55.03 & 0.3367 \\
\hline 10 & 55.53 & 16.1354 \\
\hline 11 & 59.47 & 3.9104 \\
\hline 12 & 61.51 & 129.6655 \\
\hline 13 & 71.07 & 0.5396 \\
\hline 14 & 79.45 & 0.1547 \\
\hline 15 & 83.73 & 0.8098 \\
\hline 16 & 99.43 & 8.7809 \\
\hline 17 & 101.88 & 12.4504 \\
\hline 18 & 104.76 & 0.1001 \\
\hline 19 & 135.72 & 1.7713 \\
\hline 20 & 143.19 & 0.1450 \\
\hline 21 & 171.66 & 125.0031 \\
\hline 22 & 224.77 & 1.5996 \\
\hline 23 & 244.65 & 0.2259 \\
\hline 24 & 245.91 & 5.3728 \\
\hline 25 & 248.83 & 0.7166 \\
\hline 26 & 249.81 & 328.3791 \\
\hline 27 & 274.54 & 1343.8023 \\
\hline 28 & 291.12 & 94.3299 \\
\hline 29 & 295.72 & 0.5228 \\
\hline 30 & 336.30 & 0.1775 \\
\hline 31 & 338.70 & 22.9410 \\
\hline 32 & 344.53 & 513.3596 \\
\hline 33 & 422.20 & 1.2244 \\
\hline
\end{tabular}




\begin{tabular}{|c|c|c|}
\hline 34 & 424.40 & 151.1101 \\
\hline 35 & 425.05 & 39.2073 \\
\hline 36 & 431.59 & 234.3012 \\
\hline 7 & 434.44 & 6.9612 \\
\hline 38 & 441.58 & 0.6023 \\
\hline 39 & 455.63 & 3.3986 \\
\hline 40 & 466.45 & 0.8999 \\
\hline 41 & 481.17 & 1012.2368 \\
\hline 42 & 503.36 & 67.3455 \\
\hline 43 & 504.34 & 4521.5438 \\
\hline 44 & 511.80 & 27.0066 \\
\hline 45 & 516.14 & 2.3038 \\
\hline 46 & 518.69 & 1.5475 \\
\hline 47 & 552.76 & 1487.9486 \\
\hline 48 & 568.62 & 6.7971 \\
\hline 49 & 583.75 & 0.2111 \\
\hline 50 & 623.18 & 0.9464 \\
\hline 51 & 623.93 & 3.8556 \\
\hline 52 & 624.99 & 1.1541 \\
\hline 53 & 629.96 & 16.5999 \\
\hline 54 & 630.27 & 1.9067 \\
\hline 55 & 637.36 & 78.9179 \\
\hline 56 & 637.85 & 14.8988 \\
\hline 57 & 638.93 & 483.1627 \\
\hline 58 & 651.04 & 3956.0031 \\
\hline
\end{tabular}




\begin{tabular}{|c|c|c|}
\hline 59 & 687.43 & 5246.2823 \\
\hline 60 & 712.04 & 51.1998 \\
\hline 61 & 715.09 & 51.6340 \\
\hline 62 & 716.30 & 24.9920 \\
\hline 63 & 722.14 & 77.8611 \\
\hline 64 & 725.70 & 731.4048 \\
\hline 65 & 749.33 & 2060.5653 \\
\hline 66 & 761.58 & 465.2074 \\
\hline 67 & 767.73 & 9.5015 \\
\hline 68 & 771.93 & 1251.8685 \\
\hline 69 & 778.28 & 52.8452 \\
\hline 70 & 786.27 & 17.7550 \\
\hline 71 & 788.43 & 36.2103 \\
\hline 72 & 794.23 & 313.4640 \\
\hline 73 & 798.92 & 4710.1498 \\
\hline 74 & 815.32 & 4.2859 \\
\hline 75 & 816.50 & 3.1014 \\
\hline 76 & 851.19 & 627.2771 \\
\hline 77 & 854.09 & 394.1710 \\
\hline 78 & 858.99 & 1225.7566 \\
\hline 79 & 878.30 & 22.7328 \\
\hline 80 & 887.89 & 4.0445 \\
\hline 81 & 904.34 & 227.0384 \\
\hline 82 & 910.05 & 1.8373 \\
\hline 8 & 924.30 & 1.9420 \\
\hline
\end{tabular}




\begin{tabular}{|c|c|c|}
\hline 84 & 927.77 & 2.4891 \\
\hline 85 & 929.48 & 0.9308 \\
\hline 86 & 944.97 & 2556.3294 \\
\hline 87 & 949.66 & 17.2869 \\
\hline 88 & 958.59 & 1.5614 \\
\hline 89 & 969.97 & 4.7571 \\
\hline 90 & 979.68 & 1.0983 \\
\hline 91 & 982.32 & 0.1423 \\
\hline 92 & 1002.97 & 0.5718 \\
\hline 93 & 1003.46 & 303.2228 \\
\hline 94 & 1007.16 & 240.6221 \\
\hline 95 & 1007.44 & 180.6059 \\
\hline 96 & 1008.30 & 149.2557 \\
\hline 97 & 1009.20 & 21.0083 \\
\hline 98 & 1016.95 & 0.0796 \\
\hline 99 & 1019.22 & 78.2405 \\
\hline 100 & 1020.21 & 1.7979 \\
\hline 101 & 1021.42 & 12.1361 \\
\hline 102 & 1030.47 & 0.0690 \\
\hline 103 & 1033.03 & 0.2134 \\
\hline 104 & 1036.65 & 0.0407 \\
\hline 105 & 1040.81 & 9.8158 \\
\hline 106 & 1043.92 & 1.4733 \\
\hline 107 & 1046.24 & 41.7837 \\
\hline 108 & 1046.80 & 11.9025 \\
\hline
\end{tabular}




\begin{tabular}{|c|c|c|}
\hline 109 & 1047.66 & 10.1112 \\
\hline 110 & 1055.44 & 16.8434 \\
\hline 111 & 1060.18 & 67.4855 \\
\hline 112 & 1091.88 & 1925.5055 \\
\hline 113 & 1102.62 & 16.0540 \\
\hline 114 & 1104.87 & 5.0987 \\
\hline 115 & 1108.23 & 38.3103 \\
\hline 116 & 1110.56 & 11.1096 \\
\hline 117 & 1112.74 & 858.7151 \\
\hline 118 & 1150.25 & 16.8848 \\
\hline 119 & 1154.28 & 4348.2908 \\
\hline 120 & 1160.33 & 218.9238 \\
\hline 121 & 1164.30 & 0.4761 \\
\hline 122 & 1164.76 & 0.1846 \\
\hline 123 & 1164.96 & 27.6331 \\
\hline 124 & 1165.86 & 6.4736 \\
\hline 125 & 1168.70 & 12.2416 \\
\hline 126 & 1175.58 & 4333.1451 \\
\hline 127 & 1181.28 & 24.9656 \\
\hline 128 & 1182.38 & 30.3737 \\
\hline 129 & 1190.27 & 342.7768 \\
\hline 130 & 1210.50 & 367.3875 \\
\hline 131 & 1223.59 & 1.0343 \\
\hline 132 & 1233.26 & 2906.4657 \\
\hline 13 & 1260.32 & 1022.6709 \\
\hline
\end{tabular}




\begin{tabular}{|c|c|c|}
\hline 134 & 1297.12 & 1815.4504 \\
\hline 135 & 1299.11 & 2674.6307 \\
\hline 36 & 1303.06 & 9888.2485 \\
\hline 37 & 1308.62 & 17.1513 \\
\hline 38 & 1314.72 & 566.1049 \\
\hline 39 & 1316.42 & 3994.8134 \\
\hline 140 & 1324.96 & 9186.9776 \\
\hline 41 & 1347.83 & 33.6763 \\
\hline 142 & 1349.43 & 17.5775 \\
\hline 143 & 1351.66 & 45.9782 \\
\hline 144 & 1353.68 & 240.0943 \\
\hline 145 & 1360.76 & 10.0363 \\
\hline 146 & 1370.14 & 4.2164 \\
\hline 147 & 1371.39 & 9.9307 \\
\hline 148 & 1391.41 & 3153.5432 \\
\hline 149 & 1460.82 & 5626.5409 \\
\hline 150 & 1467.79 & 33.9445 \\
\hline 151 & 1473.61 & 848.9597 \\
\hline 152 & 1474.77 & 216.7253 \\
\hline 153 & 1487.06 & 503.2255 \\
\hline 154 & 1488.10 & 54.7780 \\
\hline 15 & 1493.71 & 3.2085 \\
\hline 156 & 1499.63 & 6369.6002 \\
\hline 157 & 1507.87 & 342.8209 \\
\hline & 1508.39 & 784.4063 \\
\hline
\end{tabular}




\begin{tabular}{|c|c|c|}
\hline 159 & 1509.68 & 268.2351 \\
\hline 160 & 1517.93 & 1787.1681 \\
\hline 161 & 1543.58 & 40738.1904 \\
\hline 162 & 1614.59 & 7.6484 \\
\hline 163 & 1615.76 & 0.5375 \\
\hline 164 & 1619.18 & 161.5025 \\
\hline 165 & 1621.70 & 1.6580 \\
\hline 166 & 1624.45 & 5.5400 \\
\hline 167 & 1625.54 & 1097.2951 \\
\hline 168 & 1632.30 & 15.7351 \\
\hline 169 & 1633.61 & 103.6080 \\
\hline 170 & 1635.26 & 0.7220 \\
\hline 171 & 1644.90 & 673.4184 \\
\hline 172 & 1652.90 & 688.6541 \\
\hline 173 & 1657.85 & 1031.1445 \\
\hline 174 & 1696.11 & 414.8429 \\
\hline 175 & 3176.64 & 43.7622 \\
\hline 176 & 3177.09 & 634.3655 \\
\hline 177 & 3177.71 & 99.6351 \\
\hline 178 & 3181.10 & 612.0792 \\
\hline 179 & 3182.47 & 47.5480 \\
\hline 180 & 3183.34 & 1117.6139 \\
\hline 181 & 3185.91 & 1375.6557 \\
\hline 182 & 3186.19 & 208.4423 \\
\hline 183 & 3187.62 & 176.8522 \\
\hline
\end{tabular}




\begin{tabular}{|c|c|c|}
\hline 184 & 3188.11 & 318.6679 \\
\hline 185 & 3189.98 & 2500.6380 \\
\hline 186 & 3190.75 & 5.0517 \\
\hline 187 & 3191.28 & 32.0406 \\
\hline 188 & 3193.61 & 11.1468 \\
\hline 189 & 3193.69 & 6.4420 \\
\hline 190 & 3197.39 & 1578.1365 \\
\hline 191 & 3199.76 & 4276.6234 \\
\hline 192 & 3200.28 & 79.4009 \\
\hline 193 & 3201.08 & 30.5163 \\
\hline 194 & 3203.94 & 42.1416 \\
\hline 195 & 3204.06 & 199.0253 \\
\hline 196 & 3210.36 & 1642.2443 \\
\hline 197 & 3210.76 & 3.0271 \\
\hline 198 & 3211.32 & 15.9256 \\
\hline 199 & 3211.91 & 492.2361 \\
\hline 200 & 3212.96 & 1744.1557 \\
\hline 01 & 3213.79 & 333.9817 \\
\hline
\end{tabular}




\subsection{Internal Reaction Coordinate Calculation for MS-CPET between $\mathrm{FIr}(\mathrm{H}) \mathrm{CO}_{2}^{-}$and $\mathbf{N}^{\bullet+}(\mathbf{P h})_{3}$}

The following coordinates are the SVP optimized candidate transition state structure for MS-CPET between $\mathrm{F} \operatorname{lr}(\mathrm{H}) \mathrm{CO} 2^{-}$and $\mathrm{N}^{\bullet+}\left(\mathrm{Ar}_{\mathrm{Br}}\right)_{3}(\mathbf{S 5 . 2 9})$.

B3LYP/def2SVP irc $=$ calcfc,MaxPoints $=100$, StepSize $=5$

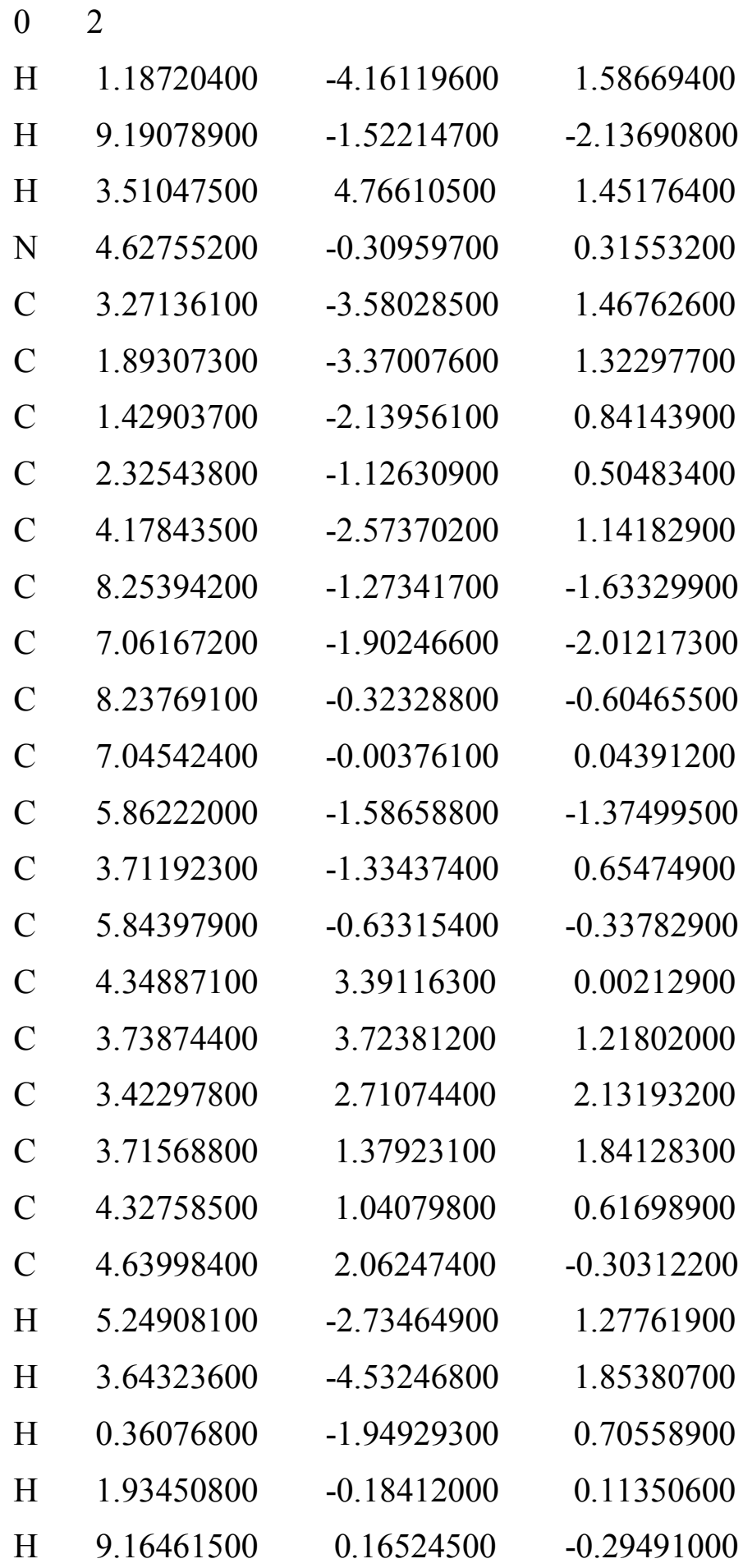




\begin{tabular}{|c|c|c|c|}
\hline $\mathbf{H}$ & 7.06233400 & -2.63723500 & -2.82081100 \\
\hline 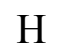 & 4.93174200 & -2.06418400 & -1.68591100 \\
\hline & 7.03996500 & 0.72277400 & 0.85805400 \\
\hline & 4.58893900 & 4.17275600 & -0.72260600 \\
\hline & 2.95611200 & 2.96074400 & 3.08759600 \\
\hline & 3.48664000 & 0.59630200 & 2.56566600 \\
\hline & 5.09707100 & 1.80734100 & -1.26040900 \\
\hline & -5.30805000 & 0.41711900 & 3.36138100 \\
\hline $\mathrm{C}$ & -6.24486200 & -0.62388500 & 3.27722000 \\
\hline $\mathrm{C}$ & -6.40971600 & -1.34608400 & 2.08553300 \\
\hline$C$ & -4.51163500 & 0.75138800 & 2.25835900 \\
\hline$r$ & -5.62416300 & -1.01373600 & 0.97964300 \\
\hline$r$ & -3.92436100 & 0.14631500 & -0.21972500 \\
\hline$C$ & -4.60514600 & -0.82911900 & -1.11827800 \\
\hline$C$ & -5.58340100 & -1.55471100 & -0.38581300 \\
\hline$C$ & -6.31751400 & -2.56949900 & -1.00368900 \\
\hline$C$ & -6.07734800 & -2.85400900 & -2.35656200 \\
\hline $\mathrm{C}$ & -4.37075200 & -1.11958300 & -2.46654000 \\
\hline $\mathrm{C}$ & -5.11630000 & -2.13358100 & -3.08171800 \\
\hline$U$ & -5.19750700 & 0.97105000 & 4.29692700 \\
\hline $\mathrm{H}$ & -6.85604900 & -0.87305000 & 4.14828700 \\
\hline 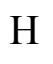 & -7.14843400 & -2.14964200 & 2.02825500 \\
\hline & -7.07422600 & -3.13157200 & -0.45036100 \\
\hline $\mathrm{H}$ & -6.64819700 & -3.64370900 & -2.85145100 \\
\hline $\mathrm{H}$ & -3.61848300 & -0.56444100 & -3.03277400 \\
\hline 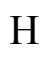 & -4.94675100 & -2.36726800 & -4.13572900 \\
\hline$r$ & -3.49540600 & 1.49784600 & -0.74190500 \\
\hline$C$ & -2.12660400 & 1.82798800 & -0.82148500 \\
\hline${ }^{2}$ & -1.73998400 & 3.08747000 & -1.30772900 \\
\hline$C$ & -2.69548300 & 4.01761600 & -1.7137430 \\
\hline$C^{2}$ & -4.05580000 & 3.69257500 & -1.63534500 \\
\hline & -4.45013300 & 2.44316700 & -1.153326 \\
\hline
\end{tabular}




$\begin{array}{lrrr}\mathrm{H} & -0.67357100 & 3.31432300 & -1.35781200 \\ \mathrm{H} & -2.38461200 & 4.99498500 & -2.09104000 \\ \mathrm{H} & -4.81211800 & 4.41593700 & -1.95106900 \\ \mathrm{H} & -5.51204100 & 2.19124000 & -1.09301300 \\ \mathrm{C} & -1.03322900 & 0.86203800 & -0.39764900 \\ \mathrm{O} & 0.15164600 & 1.19510400 & -0.48039100 \\ \mathrm{O} & -1.40544800 & -0.29796100 & 0.04211500 \\ \mathrm{C} & -4.67028500 & 0.03629800 & 1.06650600 \\ \mathrm{H} & -3.77866100 & 1.55905000 & 2.32976700 \\ \mathrm{H} & -2.80250700 & -0.31397300 & -0.00194600\end{array}$




\section{References}

1 Rhile, I. J.; Markle, T. F.; Nagao, H.; DiPasquale, A. G.; Lam, O. P.; Lockwood, M. A.; Rotter, K.; Mayer, J. M., Concerted proton-electron transfer in the oxidation of hydrogen-bonded phenols. J. Am. Chem. Soc. 2006, 128, 6075-88.

2 Morris, W. D.; Mayer, J. M., Separating proton and electron transfer effects in three-component concerted proton-coupled electron transfer reactions. J. Am. Chem. Soc. 2017, 139, 10312-10319.

3 Connelly, N. G.; Geiger, W. E., Chemical redox agents for organometallic chemistry. Chem. Rev. 1996, 96, 877-910.

4 Markle, T. F.; Darcy, J. W.; Mayer, J. M., A new strategy to efficiently cleave and form C-H bonds using proton-coupled electron transfer. Sci. $A d v$. 2018, 4, eaat5776.

${ }^{5}$ Chen, J.-J.; Onogi, S.; Hsieh, Y.-C.; Hsiao, C.-C.; Higashibayashi, S.; Sakurai, H.; Wu, Y.-T., Palladiumcatalyzed arylation of methylene-bridged polyarenes: synthesis and structures of 9-arylfluorene derivatives. Adv. Synth. Catal. 2012, 354, 1551-1558.

${ }^{6}$ Izutsu, K. Acid-base dissociation constants in dipolar aprotic solvents; Blackwell Scientific Publications: Oxford, 1990.

${ }^{7}$ Binstead, Zuberbühler and Jung Specfit, version 3.0.36 (32-bit Windows), Spectrum Software Associates: Chapel Hill, NC: 2004.

${ }^{8}$ Warren, Tronic and Mayer, Thermochemistry of Proton-Coupled Electron Transfer Reagents and its Implications. Chem. Rev. 2010, 110, 6961-7001.

9 Waidmann, Miller, Ng, Scheuermann, Porter, Tronic and Mayer, Using combinations of oxidants and bases as PCET reactants: thermochemical and practical considerations. Energy Environ. Sci. 2012, 5, $7771-7780$. 